\title{
RADICAL RIGHT PARTIES IN EASTERN EUROPE
}

\author{
By \\ Horia Nedelcu

\begin{abstract}
A thesis submitted to
the Faculty of Graduate Studies and Research

in partial fulfillment of the

requirements for the degree of
\end{abstract}

Masters of Arts

Institute of European, Russian and Eurasian Studies

\author{
Carleton University \\ Ottawa, Ontario
}

May 2009

(C) 2009, H. Nedelcu 
Library and

Archives Canada

Published Heritage

Branch

395 Wellington Street

Ottawa ON K1A 0N4

Canada
Bibliothèque et

Archives Canada

Direction du

Patrimoine de l'édition

395 , rue Wellington

Ottawa ON K1A 0N4

Canada

Your file Votre référence

ISBN: 978-0-494-51976-9

Our file Notre référence

ISBN: 978-0-494-51976-9

NOTICE:

The author has granted a nonexclusive license allowing Library and Archives Canada to reproduce, publish, archive, preserve, conserve, communicate to the public by telecommunication or on the Internet, loan, distribute and sell theses worldwide, for commercial or noncommercial purposes, in microform, paper, electronic and/or any other formats.

The author retains copyright ownership and moral rights in this thesis. Neither the thesis nor substantial extracts from it may be printed or otherwise reproduced without the author's permission.
AVIS:

L'auteur a accordé une licence non exclusive permettant à la Bibliothèque et Archives Canada de reproduire, publier, archiver, sauvegarder, conserver, transmettre au public par télécommunication ou par l'Internet, prêter, distribuer et vendre des thèses partout dans le monde, à des fins commerciales ou autres, sur support microforme, papier, électronique et/ou autres formats.

L'auteur conserve la propriété du droit d'auteur et des droits moraux qui protège cette thèse. $\mathrm{Ni}$ la thèse ni des extraits substantiels de celle-ci ne doivent être imprimés ou autrement reproduits sans son autorisation.
In compliance with the Canadian

Privacy A'ct some supporting forms may have been removed from this thesis.

While these forms may be included in the document page count, their removal does not represent any loss of content from the thesis.
Conformément à la loi canadienne sur la protection de la vie privée, quelques formulaires secondaires ont été enlevés de cette thèse.

Bien que ces formulaires aient inclus dans la pagination, il n'y aura aucun contenu manquant.

\section{Canadä}




\begin{abstract}
The far right is the most extensively studied political party family in academic literature. Yet for the past thirty years, attention has been almost exclusively focused on the Western European radical right parties, which have been associated with post-industrial societal changes and exposure to increasing international competition that have reshaped socialization in the working environment. For this reason, the new radical or far right parties in the west have been regarded to favour free-market and authoritarian policies. Meanwhile, their eastern counterparts (wherever they existed) have been utterly ignored and brushed aside as Parties of the Communist Past - that is, mere offsprings of former communist party elites in search for new constituencies. Consequently, with the exception of Cas Mudde's book on a pan-European extreme right phenomenon, scholarly literature rarely treats the two together due to the perceived intrinsic differences between them. With the advent of European Union integration, however, the eastern radical right deserve a deeper study. This thesis, with a focus on Romania and Bulgaria, will explore whether rapid reforms and "catching up" as well as EU integration have transformed Eastern European societies to such a degree that the supply and demand for the radical right start to resemble more and more the western European scenario, thus resulting in new neo-western radical right parties in Eastern Europe competing with the old-eastern far right.
\end{abstract}




\section{Acknowledgements}

I wish to thank my supervisor, Professor Joan DeBardeleben for her precious and patient supervision as well as full support during my research and completion of this thesis. Likewise, I would like to thank Professor Achim Hurrelmann for his valuable help and direction as well as Professor Marian Preda of the Faculty of Political Studies in Bucharest and Professor Dr.Vlad Nistor of the Romanian Diplomatic Institute for their crucial assistance and input.

Furthermore, this research would not have been possible without the help from the Centre for European Studies at Carleton University, Ottawa. I would like to thank all the interviewees for their time and patience, especially Tsvetan Tsvetanov of GERB Party, Trache Nicolae Petre, Secretary General of New Generation Party and Voicu Mihaita of Greater Romania Party. 


\section{Table of Contents}

Abstract

Acknowledgements

Table of Contents

List of Tables and Figures

List of Acronyms

Chapter 1: Introduction

1.1 Background

1.2 Methodology

1.3 Outline

1.4 Research Question

1.5 Hypothesis

Chapter 2: Conceptualizing the New -Western - Radical Right: A Review of Previous Studies on Demand and Supply

2.1 Introduction: The Western Radical Right

2.2 Demand-Side of the Radical Right

2.3 Supply-Side of the Radical-Right

2.4 Comprehensive Approach towards an Understanding of the Radical-Right

Chapter 3: Romanian and Bulgarian Radical Right: Legacies and post-1989 Politics 35

3.1 Introduction: The Radical Right in Romania and Bulgaria 35

3.2 Historical Link - Radical Parties of the Past 36

3.3 PRM and ATAKA 44

3.4 Radical Right in the post-1989 Party System 47

3.5 Conclusion $\quad 53$

Chapter 4: The EU and the Radical Right in Romania and Bulgaria 56

4.1 Introduction: Romanian and Bulgarian Radical-Right 56

4.2 EU Passive Leverage and the Radical Right 58

4.3 The Radical Right during EU active-leverage $\quad 67$

4.4 Seeking alternatives: 2000 and 2001 Elections 72

4.5 Elections and EU membership Negotiations 76

4.6 Conclusion $\quad 80$

Chapter 5: Reactions to Euro-Atlantic Integration: Changes in the Political Space $\quad 82$

$\begin{array}{ll}5.1 \text { Introduction } & 82\end{array}$

5.2 The New Radical Right in Bulgaria and Romania $\quad 84$

5.3 Effects of EU Integration $\quad 91$

5.4 Electoral Systems and the Radical Right 97

5.5 Conclusion 107 
Chapter 6: Conclusion

6.1 Overview

6.2 Theoretical Framework

118

6.3 Outlook

121

List of Interviews

125

Bibliography

126 


\section{List of Tables and Figures}

Figure 1 - The Competitive Space of Political Parties in Western Europe in the 1980s. pg. 20 (Kitschelt 1995, 15)

Figure 2 - Political Spectrum in Romania and Bulgaria in the Early 1990s .pg. 63

Figure 3 - Political Spectrum in Romania and Bulgaria between 1995-2005. ..pg. 69

Figure 4 - Bulgarian and Romanian Legislative Election Results of 2005 and 2004. pg. 77

Figure 5 -Most recent National Legislative and European Parliament (EP) Elections in Bulgaria and Romania.

Figure 6 - Political Spectrum in Romania and Bulgaria in the late 2000s. .pg. 96

Figure 7 - Chronology of the Shifts of the Romanian and Bulgarian Political Space between 1990 and 2009 . 


\section{List of Acronyms}

ATAKA - ATAKA Party

AN - Alleanza Nazionale (National Allience)

BSP - Bulgarian Socialist Party

CEE - Central and Eastern Europe

$\mathrm{CR}$ - centre-right

DSB - Democrats for a Strong Bulgaria

EP - European Parliament

FDI - foreign direct investment

GERB - Citizens for European Development of Bulgaria

ITS - Identity, Tradition and Sovereignty

MRF - Movement for Rights and Freedoms (in Bulgaria)

MSI - Movimento Socialisto Italiano (Italian Social Movement)

NGP - New Generation Party (in Romania)

NRR - new radical right

PD - Democratic Party (in Romania)

$\mathrm{PR}$ - proportional representation

PRM - Partidul Romania Mare (Greater Romania Party)

PUNR - Party of Romanian National Union

$\mathrm{RR}$ - radical right

SD - social democrats

SDP - Social-Democratic Party (in Romania)

SNS - Slovak National Party 


\section{Chapter 1}

\section{Introduction}

\subsection{Background}

On January $9^{\text {th }} 2007$, European mass media expressed dismay, as extremists from the west and the east shook hands and came together to form Identity, Tradition and Sovereignty (ITS), the new nationalist political group in the European Parliament. It was the year that marked the end of the fifth and, as of yet, the final EU enlargement. Paradoxically, its first result seemed to be the consolidation of those that spoke against the very union that brought them together in the first place. ITS was indeed as bizarre as it was frightening: a strange mélange of the populist, nationalist-regional and extreme right parties of the west together with communist-nostalgic nationalists of the east. Newspapers cried "racists of the world unite" as it seemed that the new union was a rock-solid pan-nationalist alliance. However, the true union between Western and Eastern European radical right parties became in fact apparent ten months later when, ironically, ITS ceased to exist. Its quick end was prompted largely by internal disagreements. However most importantly, ITS was under attack by changes in the very eastern European states that supplied a considerable part of its ranks to begin with.

European Parliament elections in Romania and Bulgaria revealed a new brand of radical right, one that had little to do with and in fact was strongly in competition with the more established traditional Eastern European radical right parties that had dominated the extremist end of the political spectrum up until that time. The European Parliament elections of 2007 in 
these two states exposed just how outdated, unreformed and out of touch the old eastern right had become. The praising of past communist leaders, the call to halt the entry into the European Union and slow down economic liberalization as well as the finger pointing towards ethnic minorities as the main causes for crime and societal degeneration - just didn't quite seem to have the same effect anymore. The electorate that at one time would rally behind these messages was no longer interested in the traditional scapegoats and it definitely was not interested in anything that would remind them of what they perceived as the main reason for them joining the EU so late in the first place-communism.

Moreover, the traditional extremist electorate was no longer limited to one choice but was now in the position in which it could chose between two models of radicalism. One was the already mentioned old communist-nostalgic, anti-statist, strongly xenophobic model since the 1990s onwards. The other was one that caught on and clung to the euphoria of EU integration and instead of resisting it, capitalized on it, supported it and worked with the new realities of the day in order to establish itself in Romanian and respectively Bulgarian politics. The effect of the 2007 European Parliament elections on the radical right passed somewhat unobserved as firstly, such elections are often viewed as mere mid-terms for the national elections and secondly, attention was rather concentrated on the issues discussed by the mainstream parties. It is only after latter polls and elections that the same scenario has been reconfirmed again and again.

The questions that nevertheless arise are, who are these newcomers and how exactly did they come about? Most importantly, how does their arrival change previous theories on the radical right in the west and east as well as the claim by previous studies that the two are essentially different? 
Consequently, this thesis will aim at answering these very questions, in the attempt to formulate a new updated theory on the radical right in Eastern Europe. Perhaps, just as importantly, this thesis will confirm that despite the already extensive and numerous studies on the far right, the phenomenon, in light of the Holocaust during World War II, the devastation of the Balkan wars as well as the general threat it poses to democracy, deserves a constant study as well as a tireless watch over the transformations, re-inventions, and renovations that the partyfamily is experiencing or might experience in order to foresee and prevent such horrors from ever happening again.

The focus of this thesis on the radical right, despite the "Eastern European" geographical label, is largely centered on two countries, Romania and Bulgaria. The reason for this is because the evolution of the radical right in both these states has been substantially different than in other places of Central and Eastern Europe. Politics in Romania and Bulgaria have been characterized by a strong radical right thrust unseen in the other states of the region. In fact, with the occasional exception of Poland's LPR and Slovakia's SNS, Eastern European states have not had significant successful radical right parties at all right after 1989. This is what leaves these two states as the only ones in their region with strong communist-nostalgic far-right parties. Romania and Bulgaria are, consequently, particularly unique among countries emerging from communism in that the radical right established itself here early on and, due to the uniqueness of their communist regimes, has made these countries particularly interesting to study from an academic point of view.

Remarkably enough, while the new right is the phenomenon in the western half of the continent, the far-right in Eastern Europe has been so far considered by academic literature to be one of the past. The reason for this is due to the fact that the Eastern European radical right has 
inherited the nationalism of the communist ideology within their respective countries. These forces are likewise xenophobic but praise communist history and its achievements, usually replacing the words "socialist accomplishments" with "national accomplishments". Lastly, they externalize guilt for the historical wrongs done by one's people towards the other ${ }^{1}$

It is these parties that have been generally more successful in Eastern European postcommunist elections in that they captured the lion's share of the radical constituency. This is due to the Communist authoritarian rule and its successful elimination of past extreme nationalist elites during the 1945-1989 period, making room therefore for a communist resurrection of nationalism. This argument, based on path dependency, suggests that wherever communist elites managed to create strange hybrids between Marxist-Leninist ideology and excessive patriotism or nationalism, post-communist political systems were prone to have strong parties of the communist past.

The Greater Romania Party and ATAKA, the two (until now) successful Eastern European radical parties which for a short period of time were part of ITS, are both falling within this category. National-communism was very much characteristic of Bulgaria's authoritarian regime but most importantly of Romania under Ceausescu's dictatorship. As a consequence, it comes to no surprise that ATAKA makes references to the glorious socialist past or that the head of the Greater Romania Party is an admirer and former court poet of Ceausescu himself.

What is more important and interesting to observe however, is that this assessment is accurate when analysing the first decade of post communist politics in those states but it is no longer relevant when taking into account the performance of these parties in recent elections.

\footnotetext{
'Michael Shafir, "Marginalization or Mainstream? The Extreme Right in Post-communist Romania", in The Politics of the Extreme Right: From the Margins to the Mainstream, Paul Hainsworth, (New York: Pinter, 2000), 250-251.
} 
Given the arrival of new parties which contend and compete with the aforementioned traditional radical right during elections, this thesis will attempt to account for this phenomenon on the political spectrum in these states by analysing societal alterations, organizational changes as well as institutional transformations which could have been responsible.

This thesis will therefore illustrate the comparison between what has been dubbed the successful new radical right in Western Europe and the evolution of the radical right during the past twenty years in the eastern half of the continent, aiming ultimately to establish a more generalizeable pan-European theory regarding the new right.

Success - that is to say, the success of the new radical right - should not be understood only as rise to power or the accumulation of enough seats to form government. Indeed, with the exception of Haider's Freedom Party in Austria there are hardly other such cases in Europe. Success should rather be regarded as the ability of such parties to simply make it to parliament or provide a strong enough presidential candidate, regardless of the perceived insignificance that this might have in the long run. Regardless if a Petain or a Vadim Tudor would have never been able to truly effectively challenge mainstream candidates and regardless of the $5-10 \%$ popular vote that these parties generally receive, the very fact that their message receives so many votes and translates into parliamentary seats is enough reason for concern; once running against incumbent presidents, once in parliament, and once at the forefront of media attention they are no longer fringe-political parties but as little influence as they have, they become part of politics. Success is therefore their ability to become just that.

The ability to be successful will be determined, for the purpose of this thesis, through a measure of four factors: 1) supply of the radical right, 2) popular demand for the radical right, 3) internal institutional factors favoring or hindering the demand/supply as well as 4) external 
factors influencing the demand/supply of the radical right within the states studied. The analysis of the demand for and supply of these parties within the respective institutional environments will not claim to seek an answer to the question "which influences the other" but rather will confirm Pippa Norris' conclusion that understanding party politics means understanding that the political space resembles a market where demand and supply are vigorously interrelated ${ }^{2}$. The success of the radical right therefore cannot be achieved by the presence of one without the other. Rather, a strong demand combined with strong supply (that is to say, a charismatic leader and a strong party leadership) are the formulae for success.

Acting as the

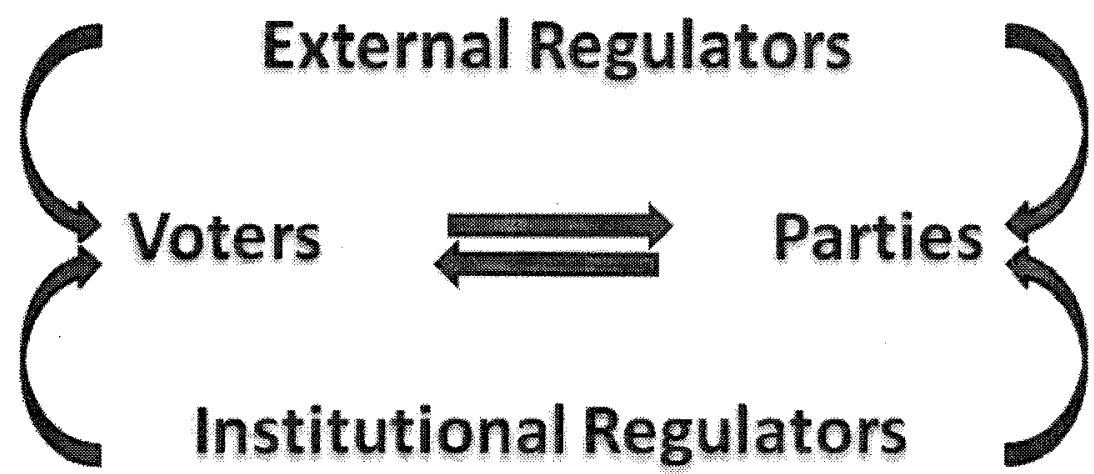
regulators of the electoral marketplace, institutional aspects such as electoral rules, legislation as well as election thresholds favoring small parties like those on the radical right, will subsequently project both supply and demand, thereby increasing their chances of success. Finally, for the purpose of expanding the institutional aspects beyond "internal regulators" (meaning national or state institutions), external regulators such as the European Union vis-à-vis Romania and Bulgaria must likewise be considered as the EU has been a crucial actor in shaping both the demand as well as the supply of political parties in these two states ${ }^{3}$. Therefore, the success of the radical right must be sought in the party demand and party supply

\footnotetext{
${ }^{2}$ Pippa Norris, Radical Right: Voters and parties in the Electoral Market (NY: Cambridge University Press, 2005), 4.

${ }^{3}$ Cristian Preda, Faculty of Political Studies Bucharest - interview conducted in 2008.
} 
within a carefully regulated marketplace ${ }^{4}$, where the regulators can be both internal as well as external.

\subsection{Methodology}

The broad question this thesis is trying to answer is: What accounts for the rise of new radical right in the Eastern European space which, due to the circumstances of post-communist transition, has experienced a political development significantly different from that in the western half of the continent? Primarily, the study will be focused on Romania and Bulgaria, states that have witnessed the superimposition of a new radical right over an already established leftist-nationalist local brand. The aim is to dissect the relationship between party leadership and voters' preferences as well as external and internal regulators affecting both, in order to understand which factor(s) have been responsible for new early $21^{\text {st }}$ century far right parties in Eastern Europe.

The approach employed will therefore be explanatory rather than descriptive. The methodological process for the thesis will be as follows: a) assess, identify and establish the general characteristics of the new radical right in Western Europe, in large part through an examination of existing literature; b) investigate the emergence of post-communist Eastern European radical right within the immediate post-1989 political system of Eastern and Central European states; c) examine post-1990s late-transition changes in Eastern European countries

${ }^{4}$ Pippa Norris, Radical Right: Voters and parties in the Electoral Market (NY: Cambridge University Press, 2005), 4. 
and the impact upon the radical right; d) reassess current conceptualizations regarding the new right in search for a pan-European theory.

The research material used in this thesis is composed of primary as well as secondary sources. The latter include a number of documents, scholarly articles and works focused on the re-emergence of the radical right in Eastern Europe. The former, due to a lack of recent studies and quantitative data, consist of official party doctrines and programs, opinion polls and personal interviews conducted with NGO directors, academics as well as party leaders in each of the countries studied.

\subsubsection{Reviewing Existing Studies}

Existing literature provides important guidance in the context of this study. First, by consulting already existing literature, it is possible to arrive at a detailed and accurate characterization of the 'new radical right party' in Western Europe before proceeding with a study of its Eastern European counterpart. This is because, although the terminology "new radical right" or sometimes "extreme right" has been introduced, the exact definition of the Western European "new right" must be clearly established for the purpose of this study in order to determine whether its Eastern European new counterpart falls within this definition or not.

Secondly, although few in numbers, works on Eastern European parties or pan-European approaches can serve as the backbone of the present study which aims to take into account the most recent developments in the political systems of these countries. Such studies are therefore essential not only in providing a background of the political systems in Eastern Europe but also 
in helping to ascertain the reasons for these new changes. An examination of findings from existing literature is found in the literature review below.

\subsubsection{Primary Resources}

As mentioned previously, this thesis will attempt to explore the relationship between external influences, electoral rules, party leadership and voter preferences in order to understand which factor(s) have been responsible for the rise of the new far right parties in Eastern Europe. Primary resources will consequently be used in order to explore the strengths of each of the three elements mentioned above.

\section{a) Opinion Polls}

Polls on party preference as well as opinion polls on the electorate's policy position are essential in assessing the importance of the demand side of parties. Such polls include BBSS Gallup and Alpha Research in Bulgaria as well as Gallup and IMAS in Romania. All four contain data from the early 1990 s to the present and almost all are available in English as well as the respective national language. The polls are especially revealing as they often include not just data on voters' preferences in these states but also on voters' socio-economic conditions, popular opinion on the government's performance, the economy, globalization, and societal issues. Consequently, these polls highlight the characteristics, socio-economic backgrounds and political views of voters in those states, allowing one, therefore, to link these features with voting patterns. It is expected that wherever Eastern European voters display similar characteristics to voters in Western Europe, the political systems in these states will experience the formation of a vacuum for new far-right parties (similar to those in the west) to form. 
Moreover, in some cases, in the absence of recent election data, polls can be the next best indicative for analytical purposes of the performance of these parties. This is the case of the Bulgarian parties in particular as the next national election will take place in late 2009 and consequently such election data is not yet available for analysis.

b) Party Doctrines/Programs and Speeches

The post-1989 vacuum formed, which allowed for the radical right parties to emerge, does not just depend on public opinion but also on the dynamics of parties themselves. For this reason, an analysis of party doctrines, programs and speeches becomes crucial. When addressing the supply-side of parties, the most evident resources available are the doctrines and programs of the parties themselves.

Moreover, speeches in parliament, press releases and important declarations by party members or party leaders are also likely to shed light into the importance of the party itself in its eventual success or failure in elections. The aim of focusing on these factors is to determine whether the doctrine and speeches are consequent to a demand from voters or whether the parties are responsible for their own success. This will be measured in the tone of each doctrine/speech as well as the specific audience (if any) that it reaches towards.

c) Interviews

In establishing an understanding of the supply as well as the demand-side for new radical parties, interviews conducted with party representatives as well as leaders of NGOs and academics are particularly useful. This is because the questions the interviewees were faced with, 
specifically sought an answer to the very question of this thesis. Consequently, interviews with party leaders and representatives had the aim to confirm the relationship between electoral rules, voter preferences and party leadership but also to observe the presence or lack of awareness on the part of those leaders vis-à-vis the changes suffered in this link.

Moreover, in light of the absence of academic studies, interviews with academics and NGO representatives have had the aim of providing an objective view on the emergence of such parties. Finally, all interviews sought to discover whether the interviewees were conscious of the similarities between the new radical right in their countries and those already present in the west. All taped interviews were approved by the Carleton Ethics Committee, 2008.

\section{d) Electoral rules}

Finally, electoral rules (available on the World Wide Web) in each of the aforementioned states will be explored. High thresholds and majoritarian systems are expected to hinder the consolidation of radical parties as well as their emphasis on a particular ideology $y^{5}$. By contrast, proportional representation and low thresholds are likely to permit the development of a party ideology, thus allowing one to test for the relationship between societal changes and changes in party strategy. Changes in electoral rules will be explored in order to determine whether the arrival of the new right is or may have been partly linked to changes in the rules of the game.

\footnotetext{
${ }_{5}^{5}$ Pippa Norris, Radical Right: Voters and parties in the Electoral Market (NY: Cambridge University Press, 2005), 215.
} 


\subsection{Outline}

The remaining part of this thesis will be divided into five chapters. Chapter 2 Conceptualizing the New -western - Radical Right aims at establishing a blueprint of the new radical right through an analysis of previous literature mainly focusing on Western Europe. As previously mentioned, this is important for the establishment of a working model of the new radical right party that would take account of both the supply-side as well as demand-side for such parties as well as for determining the causes responsible for its success.

Chapter 3 - Romanian and Bulgarian Radical Right: Legacies and post-1989 Politics attempts at juxtaposing the typical western radical right party with the radical parties in Eastern Europe - nostalgic for the communist past. Specifically, the chapter aims to explain the differences between the western radical right and the extreme parties right after 1989 through an analysis of the specific historical circumstances that altered both the demand as well as supply side, ultimately creating a local new brand of radicalism deeply rooted in national communism.

Chapter 4 - The EU and the Radical Right in Romania and Bulgaria - will study the integration in western institutions, economy transformations and privatization responsible for the alterations in Eastern European societies. This chapter will attempt to explore the performance of the radical right during the 1990 s and late 2000 s and the effects of EU integration on the radical right in the East.

Chapter 5 - Reactions to EU Integration: Changes in the Political Space - will attempt to establish the similarities between Western societal transformations in the 1980 s and postcommunist transformations in the East thus suggesting similar changes in voter preferences. The chapter will highlight the emergence of a neo-western radical right following the 2004/2005 
parliamentary elections and the 2007 European Parliamentary elections as well as uncover the underlying reasons for the changes in either voter preferences or party leadership (or both) that may have had a significant impact in the changes of the political map in Eastern European states. This chapter will attempt to establish the similarities between Western societal transformations in the 1980s and post-communist transformations in the East thus suggesting similar changes in voter preferences.

Chapter 6 - Conclusion - will summarize and wrap up the findings of this study, integrating them into a theoretical framework and will ultimately present a pan-European definition of the Far Right taking into consideration the developments of the party-family in Eastern European countries.

\subsection{Research Questions}

The primary question this thesis is trying to address is - what accounts for the rise of new radical right parties in Eastern European politics during the mid 2000s, characterized until recently by a radical right nostalgic of pre-1989 communist-nationalism. This question also implies an explanation of the developments regarding the old radical right (of the communistpast) up until that point.

\subsection{Hypothesis}

Before attempting to formulate a hypothesis and for the purpose of this study, it is important to state the underlying assumptions of this thesis. Firstly, I will not challenge the assumptions that societal changes have occurred in Western Europe during the 1980s which have 
reshaped voters' preferences, thus allowing for the rise of the new-right. This fact has been largely accepted in academic work.

Secondly, I do expect that the supply-side of parties, that is the ability of parties to present themselves as feasible political options and appeal to voters is crucial to party success. I will therefore look towards party leader charisma as well as effective parry leadership as the two essential ingredients for a successful radical party.

Thirdly, I will adhere to the findings of previous works and studies, particularly by Pippa Norris, which consider that it is the complex relationship between demand and supply rather than just demand or just supply that explain the full picture of the success of the radical right party family.

Fourthly, I will assume that regulators of the demand/supply of political parties are crucial elements to their success or failure. Consequently, I will consider institutional constraints in the form of electoral rules, thresholds or anti-hate legislation as possible variables affecting the supply-demand dichotomy ${ }^{6}$. I expect that those electoral rules favoring large parties will be critical obstacles for the entry of such parties in national parliaments. This is because the radical rights are generally periphery, non-mainstream parties and subsequently can accumulate lesser percentages of popular votes. On the other hand, electoral rules favoring smaller parties will be likely to positively influence the chances of radical right parties to make it into parliament.

Perhaps a novel element in the study of the radical right (particularly the radical right in Eastern European states), this thesis will also assume that not only internal (state) regulators can affect the political marketplace and thus also the radical right party family. I will therefore

\footnotetext{
${ }^{6}$ In the absence of documentation of the latter, my focus will be largely oriented towards electoral rules.
} 
extend the idea of regulators to include external factors such as the European Union and the power of EU conditionality vis-à-vis political parties as well as voters, a feature which I will explore extensively in Chapter 4 as well as Chapter 5.

When speaking of the Eastern European radical right, I will adhere to the assumption that the early East European successful far-right parties have been offsprings of ex-communist elites nostalgic for the pre-1989 era. A history of communist nationalism in these states as well as the nature of the radical right immediately after 1989 will confirm this assumption in Chapter 3 and will further elaborate on the performance and strengthening of these parties during the late 1990s and early 2000s in Chapter 4.

Nevertheless, I do expect that, over time, as Eastern European democracies have matured and as Central and Eastern European states have pursued privatization, economic reform and liberalization as part of their attempt to join the European Union, new societal preferences have been developing which inevitably have translated into a shift in demand. Consequently, the East European far right has moved towards advocating authoritarianism and a free-market, reflecting therefore similar changes in the east as those that have occurred in late $20^{\text {th }}$ Century Western Europe. In other words, my preliminary hypothesis is that exposure to international market competition, changes in the working environment and even immigration have had similar effects on voters' preferences all over the continent, resulting in similar new radical right parties emerging west as well as east of the former Iron Curtain.

Ultimately, I hypothesize that a shift in demand combined with a strong supply side - that is to say, a strong and effective party leadership - while at the same time enjoying a relaxed set 
of rules of the game is the perfect mélange for an Eastern European political system characterized by new radical right parties similar to those in the west. 


\section{Chapter 2.}

\section{Conceptualizing the New -Western - Radical Right:}

A Review of Previous Studies on Demand and Supply

\subsection{Introduction: The Western Radical Right}

The terminology "new radical/extreme right" has made its way into academic parlance, yet the party family remains one of the most varied and heterogeneous in modern European politics. Although membership in the party family is not universally accepted, it is quite clear as to which parties are not part of it. The new right is not a mainstream party. The new right $i s$ instead a party hovering at the periphery of the political spectrum. The new right is not the old right - it is not attacking the capitalist order as its Fascist predecessor did before WWII. Instead, it praises it. In fact, it aims at reducing the state to ensure its continuity. Consequently, the periphery it clingers to, is the right pole of politics, and therefore never the left like its Fascist precursor.

The new right, however is not a complete break with the old right either. It did borrow significantly from it. The new right like the old right is a party led by a populist charismatic leader. It is a party with an affinity for authoritarianism. Most importantly, it is a party demonizing the other in political discourse. In other words, the new right (much like the old right) is racist, intolerant towards minorities, anti-Semitic and in an age of globalization and movement of people, it is also anti-immigration. This is by no means a complete definition however albeit the occasional exceptions, it is the most accepted definition. Consequently, while scholars agree that this is what the new right party looks like, how it managed to mature into a modern political reality is the point where scholars begin to disagree. 
This question of "how did they come about", (that is, how the successful new right come about) is also linked to another question, "who exactly is a member of the new right". The second question is important because despite the fact that the aforementioned definition can be applied to a vast array of parties, the new right that is of specific concern is that group of parties which reach a level of success, make it into parliament (sometimes even government) and get to shape policy or at the very least use legislatures as platforms for their ideologies. It is those parties that, through their authoritarian and intolerant views, represent a danger to the democracies which have allowed them to surface in the first place.

Answering the first question ("how did they come about") is difficult as the answer lies in the two main assumptions that most scholars start off with when attempting to address the question. While some opt for accepting the electorate as the main source generating parties (demand-side oriented), others presume the parties themselves as being responsible for their own successes or failures (supply-side). Consequently, the explanations given by scholars on the subject are considerably affected by the emphasis they place on either the supply or the demand for these parties. It is for this reason that a quick analysis of major works is required in order to arrive at an understanding of the circumstances that allowed for the emergence of the new right in the first place. This chapter will explore this question through an analysis of previous works which focused on either the demand or supply of parties. While the list of scholars is not limited to the following four, the abovementioned approaches are epitomised in the works of Kitschelt, Carter, Mudde and Norris.

While Kitschelt focuses on the societal changes and therefore the demand-side of radical right parties, Carter and Mudde look at the supply-side, arguing that charisma and party organization are the key factors to success. Mudde, particularly, ignores economics and instead 
claims that successful new-right parties in both Eastern- and Western Europe must be promoters of ethnic nationalism, authoritarianism and populism ${ }^{7}$. Lastly, Pippa Norris claims that the political space is akin to a marketplace where there is a strong relationship between the supplyside and demand-side of parties but where the supply of parties is being considerably shaped by the electoral rules governing party competition. Each of these scholars has brought extremely important contributions to understanding the underlying reasons for the rise and development of this party family. However, they all fall short from giving a completely comprehensive account for the success or failure of far-right parties: Kitschelt ignores the supply-side, Mudde ignores the economic aspect, Norris ignores ideology and the new ideological cleavage in the postindustrial Europe. Moreover, none of the current literature, to date, manages to notice the changing aspect of the East European far-right. This is because these changes are rather new and for the most part still undergoing significant progress. This chapter, therefore, will deal exclusively with the demand-side or supply-side approach of the aforementioned authors in Western Europe only.

\subsection{Demand-Side of the Radical Right}

Kistchelt's work represents an early attempt to understand the emergence of the far right after 1979 as well as its success in parts of Western Europe. His focus is not so much on the ability of parties to aggregate support (supply-side) but rather it is centered exclusively on citizens' demand for such parties. As a result, he is concerned with the structural changes

\footnotetext{
${ }^{7}$ Cas Mudde, Populist Radical Right Parties in Europe (New York: Cambridge, 2007), 294.
} 
experienced by West European society which have opened up the vacuum necessary for these parties to emerge.

According to Kitschelt, whereas party competition in the Keynesian Welfare State after WWII was rather centered on economic issues, the transition to a post-industrial economy has compelled voters to shift their preferences from the traditional one-dimensional socialist versus capitalist axis to a two-dimensional: economically leftist (redistributive) and politically libertarian (participatory and individualistic) versus a free marketeering and politically and culturally authoritarian" $\operatorname{axes}^{8}$ (see Fig. 1). In other words, due to the increasing international

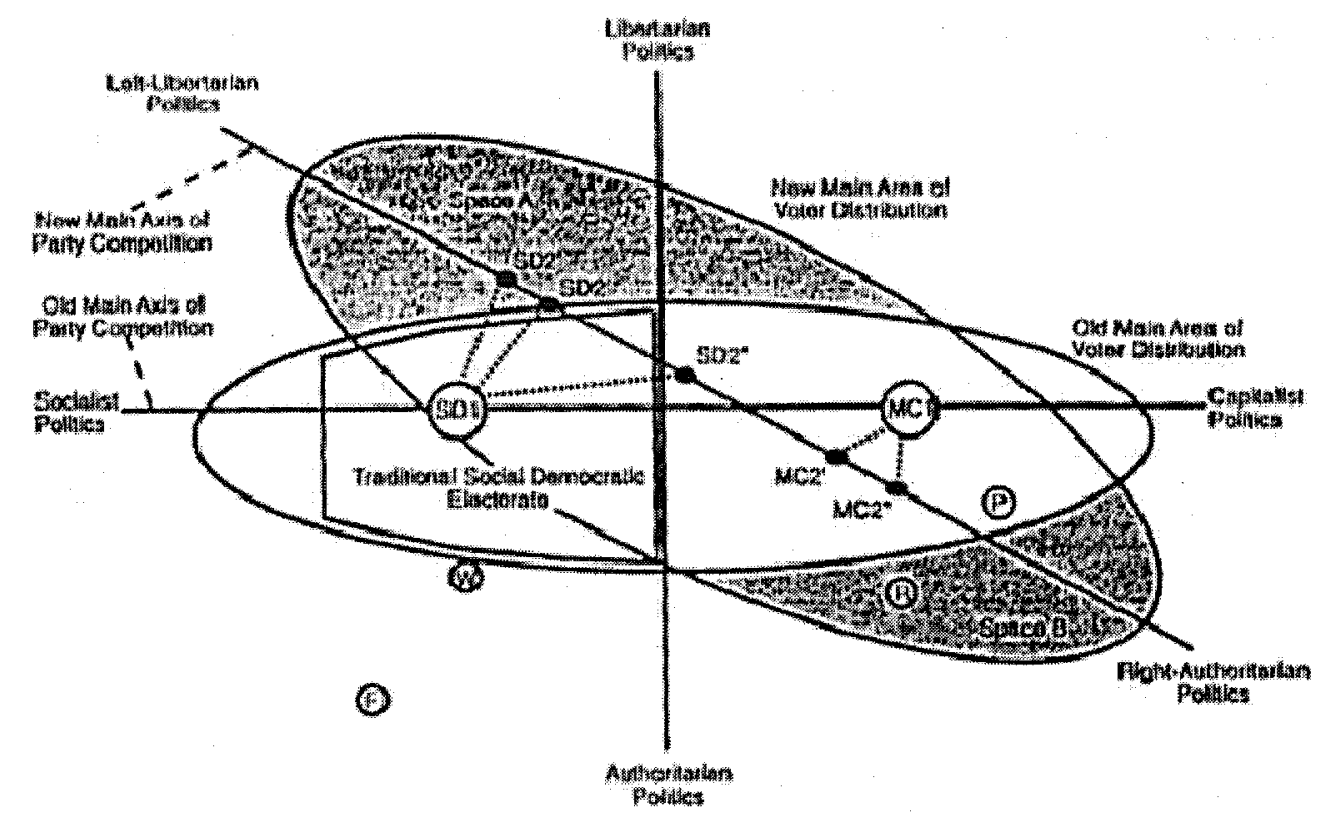

Fig. 1.1. The competitive space for political parties in Western Europe in the 1980s ( Kitschelt 1995, 15)

competition in advanced capitalism, employees develop an interest in the market viability of their own firms, thus favouring a decrease in redistributive policies which might drain away resources from investment and consumption. These actors, which generally require less

\footnotetext{
${ }^{8}$ Herbert Kitschelt, The Radical Right in Western Europe: A Comparative Analysis (Ann Arbor: University of Michigan Press, 1995), 13.
} 
education, work in instrumental economic environments guided by rules and orders, thus allowing them to identify with authoritarian versions of decision making.

Conversely, actors who are more educated work in sheltered non-tradable domestic sectors, and as a result socialize more due to their working environments, ultimately wind up identifying with a more libertarian idea of politics ${ }^{9}$. As a consequence, the groups that vote for radical-right parties are composed of blue-collar workers, petit-bourgeois and residuals such as lower salaried employees or the unemployed. White-collar employees, students and professionals belong to the latter group and as a result would be more likely to vote for leftist-libertarian parties instead. Ultimately, it is exactly those parties that manage to appeal to the former group that find the winning formulae and become in Kitschelt's view the successful 'new radical right'. All others are either populist or neo-Fascists and have so far failed to make significant headway in national elections because of the shift in popular preferences on the new two dimensional axis.

Kitschelt's argument does not put emphasis on the supply-side of parties (party organization or leadership charisma) as it is essentially focused on the demand side of parties and stresses almost exclusively the relationship between class and socialization, arguing that one's socio-economic situation affects one's working milieu, which in turn determines one's preferences for the new-right (NRR) or in retrospective for the new radical left.

Evidently, albeit somewhat similar in their authoritarian nature, the new radical right parties (NRRs) are fundamentally different from the "old Right" of the interwar-period. Whereas the old fascists are characterized by an anti-capitalist thrust, with constituencies mainly among the rural middle class, the new-right differs both on economic issues as well as on the voters it appeals to as it is pro-market and over-represented among the blue-collar workers and the petit-

\footnotetext{
${ }^{9}$ Herbert Kitschelt, The Radical Right in Western Europe: A Comparative Analysis (Ann Arbor: University of Michigan Press, 1995), 7-8.
} 
bourgeoisie of cosmopolitan cities ${ }^{10}$. Moreover, the reasons for their movements vary as well. While the new radical right has emerged due to the societal changes discussed above, the interwar fascists came about due to the economic circumstances of post-WWI Europe and the Great Depression.

For this reason, Kitschelt feels compelled to divide the new right into three sub-groups. The parties that have not managed to react to the shift in voters' preferences are the neo-fascists. They resemble the inter-war fascists and include the welfare chauvinist parties such as the German Republicans and the Movimento Socialisto Italiano (MSI), renamed Alleanza Nazionale (AN). This group, Kitschelt argues, has made very little headway in elections. Primarily, this is because only blue-collar workers would be attracted by welfare-chauvinists but not any other group in society, and certainly not elements of the bourgeoisie. The latter would be much more inclined towards the mainstream NRR parties which do not express the anti-capitalist, antibureaucratic agenda of neo-fascist ideology.

As stated previously, the second category and the most successful one, the NRR parties, are the bulk of the new radical right and by contrast they are the economist-right and authoritarian parties such as the National Front in France, Danish and Norwegian Progress Parties, the Automobilists and National Action/Swiss Democrats and the Vlaams Blok (now Vlaams Belnag/Flemish Interest) in the Flemish region of Belgium.

Finally, Kitschelt identifies a third sub-group, the populist anti-statist parties. The difference between the regular NNR and the latter lies in the flexibility of the populist parties to shift from the authoritarian towards the libertarian positions if the political spectrum allows it $^{11}$.

${ }^{10}$ Herbert Kitschelt, The Radical Right in Western Europe: A Comparative Analysis (Ann Arbor: University of Michigan Press, 1995), 30.

1 Herbert Kitschelt, The Radical Right in Western Europe: A Comparative Analysis (Ann Arbor: University of Michigan Press, 1995), 21. 
Such parties include the Freedom Party in Austria and the Northern League of Italy. Populist parties, according to Kitschelt form only in states where the distance between the mainstream socialists and conservatives is considerably smaller, thus allowing the populists to call for market-liberalism and emphasize the corrupt self-serving policies of the mainstream parties.

Kitschelt's work can be rightfully called a breakthrough in the study of the far right. His focus on economic factors and the socio-economic nature of new radical right voters is truly novel in its approach when analyzing this particular party family. Kitschelt explains the arrival of the new radical right through the changes that transpire in the form of the socialization that these classes are subjected to within their respective working environment. This leads him to conclude that the different reactions each class will have, depending on exposure to international competition or isolation, will determine class affiliation with radical-right or radical-left parties.

Moreover, his sub-classification of the new radical right is likewise based on classes. As a consequence, he assigns some classes as more sympathetic towards the NRR and other classes towards the neo-fascists. However, this type of classification which looks at society through the prism of socio-economic class has been sometimes criticized for ignoring a plethora of other forms of socialization within society which can have considerable importance as well.

For example, Kitschelt claims that the Republikaner Partei falls together with the MSI in the welfare-chauvinist subgroup, since according to him it failed to find the winning formula of the other radical right parties ${ }^{12}$. Their votes, Kitschelt argues, "are relatively less pro-capitalist then those of the other parties"13. In other words and according to Kitschelt's earlier classification of NRR parties, the German Republicans fall among the neo-fascist sub-family,

\footnotetext{
12 Herbert Kitschelt, The Radical Right in Western Europe: A Comparative Analysis (Ann Arbor: University of Michigan Press, 1995), 206.

13. Herbert Kitschelt, The Radical Right in Western Europe: A Comparative Analysis (Ann Arbor: University of Michigan Press, 1995), 66.
} 
which combines welfare oriented policies and authoritarianism, thus attracting only the bluecolor workers. This, however, has been considered a slight over-exaggeration or at the very least an over-simplification. As Karapin points out, the party members are "divided between radical and pro-Nazi wings, resulting in compromises and contradictions" $" 14$.

Minkenberg likewise observes that "analyses of the Republikaner votes in Germany such as that of Jurgen Falter reveal that up to the early 1990s this party's electoral coalition resembles the French equivalent more than Kitschelt's model suggests, with a disproportionate share of both working-class and old middle-class voters ${ }^{15}$ ". Consequently, if class exposure to postindustrial factors cannot explain the Republikaners, then other elements might play a significant role such as: alternative forms of socialization, immigration, the political or the electoral system, to just name a few. A similar situation concerns the Vlaams Belang. Kitschelt explains its success through the same class argument, yet he omits to consider other changes (this time in Belgian society) which may have made the Vlaams Belang salient, especially given the almost regionalist-ethnic nature of the party. These reviews concern the classification however, by no means, do they imply flaws existent in Kitschelt's main argument. Ultimately, all the aforementioned scholars do agree with Kitschelt that societal changes during the 1980s do in fact stand at the centre for the arrival of a new party family resembling but being completely different from the inter-war radical-right.

\footnotetext{
${ }^{14}$ Rogan V. Karapin," Radical Right and Neo-Fascist Political Parties in Western Europe," Comparative Politics 30(2) (1998): 221.

${ }^{15}$ Michael V. Minkenberg, "The Radical Right in Western Europe: A Comparative Analysis," The Journal of Politics 59(2) (1997):626.
} 


\subsection{Supply-Side of the Radical-Right}

Contrary to Kitschelt, Carter's work, written almost a decade later, focuses on the election data accumulated between 1995 (the year of Kitschelt's publication) and 2004. She uses these elections to demonstrate that parties which Kitschelt would predict to score well in elections, in actuality do not always do so, while some of those which Kitschelt considers marginal and doomed to failure, prove to be quite successful. Carter uses Austria's Freedom Party and Italy's Social Movement respectively as an example of both phenomena ${ }^{16}$. As a consequence, she infers that supply, not demand, is what accounts for success or failure in elections.

Her conclusions are that party ideology, party organization and leadership as well as the nature of ideological convergence existing between mainstream parties are the factors determining whether far-right parties score well or poorly in elections. Whereas Kitschelt's classification depended largely on socio-economic classes and their affiliation with different parties, Carter's ideology-based categorization focuses on i) the importance attached by parties to immigration, ii) the degree of parties' racism, and iii) parties' attitudes towards democracy, parliamentarism and pluralism ${ }^{17}$. She claims, therefore, that five main sub-groups of the farright exist in modern Europe: authoritarian xenophobic, neo-liberal xenophobic, neo-liberal populist, neo-Nazi and neo-fascist. She concludes that empirical evidence does seem to point out that the first three have had much more success than the latter two but that by no means is ideology the only deciding factor. Nevertheless, because of her deliberate disregard of voters'

\footnotetext{
${ }^{16}$ Elisabeth Carter, The Extreme Right in Western Europe: Success or Failure? (Manchester: Manchester University Press, 2005), 3.

${ }^{17}$ Elisabeth Carter, The Extreme Right in Western Europe: Success or Failure? (Manchester: Manchester University Press, 2005), 28.
} 
preferences, her findings do not fully explain why the former three are successful as supposed to neo-Nazis and neo-fascists. In terms of party organization, however, Carter points out that regardless of internal divisions or unity, empirical data shows that a strong organization coupled with a dynamic leadership are the two factors essential for party success ${ }^{18}$.

Neither Carter nor Kitschelt seem to believe that success is dependent on only variable. Both agree that a radical-right party is highly dependent on the political space available which it can seize. A crucial role in determining the size of this space is played by the party system and the inter-party interaction in a given state. If the mainstream parties are closer to each other on the political spectrum, then more space is left for the radical right as the conservatives are more moderate and closer to the centre. Similarly, in such cases, the radical right party benefits from its own moderation as it can reach a higher constituency. By contrast, cases of little ideological convergence on the part of mainstream parties have resulted in more radical conservatives, thus also leaving little space for the radical right to seize ${ }^{19}$. Both authors nevertheless omit to extend their findings to countries in the former communist-bloc limiting their theories only to Western Europe.

Using the same party-centric approach in Populist Radical Right Parties in Europe, Mudde attempts to bring in data from states beyond the old Iron Curtain, concluding that assumptions similar to those of Carter are true not only for Western but also for Eastern Europe as well. In his search for a definition of the far-right, Mudde, like Carter, also focuses on party ideology. He finds that nativism (ethnic nationalism), authoritarianism and populism are reoccurring features of such parties and therefore chooses to link them to his definition of the

\footnotetext{
${ }^{18}$ Elisabeth Carter, The Extreme Right in Western Europe: Success or Failure? (Manchester: Manchester University Press, 2005), 99.

${ }^{19}$ Ibid, 141.
} 
'populist radical-right' ${ }^{20}$. This classification seems rather broad as unlike Kitschelt or Carter, he does not focus on the attitude of these parties towards the market. As a consequence, Mudde's populist radical-right sub-family includes a vast array of parties such as the National Front, the Freedom Party, Vlaams Belang, Germany's Republican Party and the Danish People's Party but also Eastern European far-right parties like the Greater Romania Party, Croatia's Democratic Movement, Latvia's National Independence Movement and Kalina as well as Jirinovsky's Liberal Democratic Party of Russia.

Most importantly, Mudde challenges Kitschelt's strong emphasis on the role of economics and changes due to modern capitalism. Mudde considers the economy as a secondary issue for the populist-radical-right, arguing that the 'three pillars' of their agenda, mentioned above, are the ones which truly stand at the centre of party ideology ${ }^{21}$. If the economy matters at all, for Mudde, it is because it stems from the 'three pillars', not the other way around. This leads Mudde to include, in his populist radical-right sub-family, parties which otherwise would have been classified differently by Kitschelt's model. He demonstrates, nevertheless, that his populist radical right are rather successful in elections regardless of their pro-market or welfarechauvinist message. However, Mudde himself admits that this is in no way true of all welfarechauvinist or what Kitschelt would call 'neo-fascist' parties. In fact, Mudde admits that, "on average, Eastern European populist radical right parties are more anti-liberal and protectionist than their brethren in the West" ${ }^{\prime 22}$. He likewise notes that this is due to the legacy of the socialist past. Consequently, albeit not overlooking this rather important difference altogether, Mudde treats it quite superficially, failing to explore it further.

\footnotetext{
${ }^{20}$ Cas Mudde, Populist Radical Right Parties in Europe (New York: Cambridge, 2007), 294.

${ }^{21}$ Cas Mudde, Populist Radical Right Parties in Europe (New York: Cambridge, 2007), 137.

${ }^{22}$ Ibid, 128.
} 
Ultimately, Mudde's final revelation lies in his conclusions regarding what previous studies concerning the success of far-right parties have sought in vain to give a full description of - the ideal radical right voter. Mudde cynically concludes that such an approach is bound to fail as no such voters actually exists ${ }^{23}$. This statement is not completely groundless. On many occasions the radical-right receives a disproportionately high percentage of votes in some elections, in comparison to usual voting preferences. Such was the case of the Austrian elections of 1999 , which conferred such a large proportion of votes to the Freedom Party that it turned it into a powerful actor within Austrian politics. In subsequent elections, the Freedom Party again succumbed to its usual 10-12\%. Such instances may occur due to a number of factors, including protest voting. However, Mudde argues that even in such cases when a protest vote can be predicted, it is still difficult to calculate the number of voters who will indeed display their protest at the polls or those who will prefer to do so by staying home. Moreover, of those citizens that decide to show their dissatisfaction at the polling station, it is difficult to determine which voters will do so by voting for the radical-right parties and which ones will not.

As his analysis is a party-centric one, Mudde's explanation for irregular success seems to lie in the ability of parties to occasionally mobilize their voters or those who plan to cast protest votes effectively. The ability of parties to properly do this is strongly linked to their party organization and leadership. He states that parties are characterized either by a moderate ideology, a charismatic leader or well-structured organization. Charisma can play a crucial role for short-term success, but it cannot help the party remain in such a privileged position for long. Similarly, Mudde points out that the other two factors likewise do not guarantee success if considered in isolation. Mudde argues, therefore, that those parties like the National Front or

\footnotetext{
${ }^{23}$ Cas Mudde, Populist Radical Right Parties in Europe (New York: Cambridge, 2007), 225.
} 
Vlaams Belang that are able to combine charisma with administrative competence are the ones that will be most successful in rallying protest voters. In this respect, his findings are strikingly similar to those of Carter. However, he uses the same conclusions to explain something rather different, and that is the lack of a consistent, homogeneous element for these parties on the demand side. Essentially, by emphasizing the importance of party organization in rallying voters, Mudde, unlike Kitschelt, seems to argue that the demand side carries little importance and even when it does, a well organized party with a strong leadership can manipulate it in such a way that success is assured nevertheless. The implication here is that despite already existing societal cleavages, it is the organization and leadership that are primarily responsible for formulating ideology and setting up the issues around which the electorate can rally instead of societal cleavages influencing the supply of ideology.

\subsection{Comprehensive Approach towards an Understanding of the Radical-Right}

If Kitschlet focused on the demand for parties while Carter and Mudde on the supply side, Pippa Norris skillfully argues that the key to the success of radical right parties, either in Eastern or Western Europe, lies in understanding the dynamic interaction between both demand and supply within the conditions of imperfect competition in a regulated electoral marketplace. Norris' classification and comparison of parties is rather problematic, however. Essentially, she considers the radical right to be parties which are strongly inclined on the right, while concomitantly opposing immigration. She further divides them in 'relevant' and 'fringe' parties depending on their specific electoral strength ${ }^{24}$. This rather mechanical method of classifying the

\footnotetext{
${ }^{24}$ Pippa Norris, Radical Right: Voters and parties in the Electoral Market (NY: Cambridge University Press, 2005), 53.
} 
radical right overlooks other significant ideological elements that might prove paramount to an effective delimitation between radical-right and other borderline parties. Moreover, it calls into question whether the definition of the radical right presented by Norris is so diluted that it proves almost impossible to thoroughly analyze. This is especially problematic as, Norris herself admits that when looking particularly at Eastern Europe, one cannot speak of true 'radical right' parties or identify parties according to a left-right continuum ${ }^{25}$.

Regardless of this categorization, much like the methodology employed by Carter, Norris uses empirical election data (individual-level data), arriving at three new and surprising conclusions regarding the radical right. First, she dispels previous assumptions on the minimal importance of electoral systems. She claims that PR systems and low legal thresholds do indeed facilitate far-right parties increasing their number of seats while at times helping them to make it into parliament altogether. This is epitomized by the French National Front, which although receiving the support of $11 \%$ of the French public in the 2002 legislative elections, failed to win any seats in the National Assembly due to the second-ballot electoral system. By contrast, the Vlaams Blok has managed to gain one tenth of the seats in the Belgian Parliament with the same percentage while the Alleanza Nazionale has even held ministerial offices in Berlusconi's cabinet due to different electoral rules in these countries ${ }^{26}$. Furthermore, other rules regarding the electoral marketplace, such as limitations on opportunities for the radical right, legislation governing hate speech (such as in Belgium or Netherlands), campaign finance regulation like in Austria or Denmark and constitutional provisions banning extremist parties, like in Germany, likewise play a crucial role in limiting such parties.

\footnotetext{
${ }^{25}$ Pippa Norris, Radical Right: Voters and parties in the Electoral Market (NY: Cambridge University Press, 2005), 74.

${ }^{26}$ Ibid, 255.
} 
Secondly, Norris also dispels Kitschelt's argument of a new social cleavage, allowing the radical right to appeal to underclass low-skilled urban workers or the unemployed. She claims that the radical right, in fact, appeals to a vast array of socio-economic classes. Likewise, Norris confronts the previously assumed relationship between immigration and the success of such parties, finding no apparent link between the number of immigrants and the salience of the radical-right. On the other hand, however, she seems to agree that protest voters do seem to be rather in favour for the radical right, as a result of an erosion of institutional confidence while similarly cultural protectionism and anti-globalization further induce voters to deviate away from their accustomed choices and towards the radical-right ${ }^{27}$.

Finally, Norris dismisses the notion that the smaller the left-right gap between mainstream left and right parties is, the stronger the radical-right parties become. Instead, on the supply side, she demonstrates, using examples from France, Switzerland and Norway, that the broader electoral rules shape electoral strategies which radical right parties adopt in order to maximize votes. As a result, the degree of ideology and populism vary according to the rules. In France, which uses a majoritarian system, populism rather than ideology is emphasized in order to gain voters' appeal, while in states using proportional representation systems, both ideology and populism are important ${ }^{28}$. In other words, she claims that the supply of parties is considerably shaped by the electoral rules governing party competition.

Essentially, although failing to give a satisfactory classification of the new-right, Norris nevertheless succeeds in offering the most comprehensive study yet of radical-party behaviour within the larger view of inter-party competition and electoral limitations. Norris argues that it is

\footnotetext{
${ }^{27}$ I Pippa Norris, Radical Right: Voters and parties in the Electoral Market (NY: Cambridge University Press, 2005), 257-259.

${ }^{28} \mathrm{Ibid}, 215$.
} 
the interaction between both demand and supply factors within the broader institutional context of nomination, campaigning and electoral rules which determines radical-right party success.

\subsection{Conclusion}

Ultimately, the works reviewed attempt to explain the emergence as well as successes of new radical-right parties in Western Europe, albeit starting with different assumptions and often employing somewhat different methodologies. Kitschelt's approach does not concentrate on the supply of radical right parties as it is focused on the demand side, explaining the phenomenon as a result of societal changes leading to new cleavages across a capitalist-authoritarian versus socialist-libertarian axis.

Alternatively, Carter and Mudde employ a methodology that focuses on supply in their explanation for the differences in radical right parties' performances. While Carter explains the success of Western European far-right parties based on party organization and political space within the party system, Mudde's pan-European analysis questions the importance of the economy in radical-right parties' ideology, while emphasizing the ability of parties to mobilize voters as a crucial component in obtaining high scores. Finally, Norris' work, outlines a dynamic and complex interaction between supply and demand factors within institutional constraints, which ultimately shape party success or failure in elections.

Perhaps what is most important is that with the exception of Mudde, none of the authors have studied, let alone provided, any significant findings concerning the Eastern European parties within the radical-right family. Nevertheless, albeit a lack of consensus between the four authors, it is safe to conclude that the works examined so far reveal reoccurring features which 
can be clearly observed and which can be used in formulating a working definition regarding the new right party in the West European political spectrum.

Firstly, an institutional environment favouring small parties is essential in facilitating their success. Electoral rules and thresholds seem to have an especially pivotal and obvious institutional impact. Electoral rules favouring smaller parties have been shown to favour the radical right as parties belonging to this category are generally non-mainstream small parties. Moreover, the presence of a significant vacuum as a result of the mainstream left and mainstream right parties becoming catch-all parties (and moving towards the centre of the political space) is not detrimental to radical right parties but rather tends to favour them.

Furthermore, regarding the demand-side of radical right parties, their relative recent arrival on the political scene seems to suggest that societal changes have been responsible changes in voter preferences. The complete lack of their presence prior to the early $1980 \mathrm{~s}$ suggests the non-existence of political space available.

Finally, the supply-side is also a factor which cannot be ignored. Although the presence of a constituency is essential, party organization and the personality of party leaders strengthen party chances during elections. Academic work has proven that populism and charisma are especially valuable assets in the arsenal of the new radical right parties.

Essentially, voter preferences, institutional restraints and party organization/leadership seem to be the identifying markers of these parties. A successful radical right party is consequently, one that manages to meet demand with an adequate supply within institutional rules of the game that favour smaller parties. The definition of the radical right in the west is therefore: a non-mainstream, anti-bureaucratic, staunchly pro-capitalist, anti-immigration, well organized party, reliant on a strong charismatic powerful leader-figure. Consequently, in the 
following chapters, this thesis will attempt at exploring and accounting for the eastern counterparts of the Western new right through an analysis of the supply-demand dichotomy as well as the institutional constraints that may or may not have been responsible for their recent appearance. 


\section{Chapter 3}

\section{Romanian and Bulgarian Radical Right: \\ Legacies and post-1989 Politics}

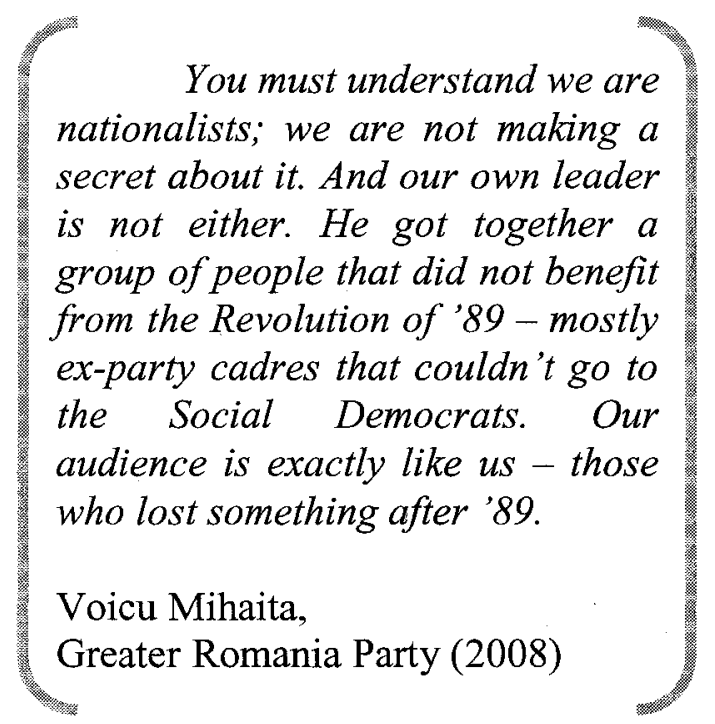

\subsection{Introduction: The Radical Right in Romania and Bulgaria}

The traditional Radical Right in Eastern Europe is different from the one in the West in almost every possible way. While the latter has had time to mature and develop since the early 1980s and in some cases even 1970s, as explained in the previous chapter, the former had less than half that time at its disposal. Secondly, while the western radical right was a reaction to societal changes during the 1980s particularly due to the increasing importance of globalization and market forces, communism insulated the eastern part of the continent from these forces until the 1990s, retarding therefore their effects in the east. Thirdly, the radical right in Romania and Bulgaria was unique due to the peculiarities of these states during the latter part of Communism 
and represented exceptions to the "norm" in Central and Eastern European (CEE) politics but most importantly made them bizarre members of the pan-European party family in general ${ }^{29}$. This chapter will aim at illustrating the peculiar historical links between these parties and the communist past as well as their performance during the roughly first decade of democracy in Eastern Europe.

\subsection{Historical Link - Radical Parties of the Past}

The historical link between the radical extreme parties of Romania and Bulgaria and the communist past lies in the peculiar nature of the communist regimes in these two states. In other words, unlike their Soviet and fellow Eastern European counterparts, Romanian and Bulgarian communist elites exploited the strong nationalist sentiment of their populations which had its roots in the years prior to 1945 . This very feature has had critical consequences on post-1989 party systems as it created a precedent which radical extremists could build up on.

In Romania, the nationalist element and nationalist sentiment of communist elites were present almost from the beginning of communist rule in that country. In fact, local-bred communist leaders had to be contained and sometimes even eliminated by the Soviet leadership almost immediately after the end of World War II particularly because their nationalism went against the official party line and indeed the communist ideology itself. These leaders were replaced up until the mid-1950s with Soviet trained Romanian communist exiles ${ }^{30}$ that were sent

29 The reasons for Romanian and Bulgarian radical right parties being unique inside the European radical/far-right party family have to do with the dissimilarity between the former and the latter on economic issues. While Romania's PRM and Bulgaria's ATAKA are parties of the communist past, advocating left economic measures, their western counterparts are, as Chapter 2 illustrated, staunchly pro-capitalist.

${ }^{30}$ Romanian intra communist party politics in the 1940 s and 1950 s were dominated by two rival factions: the "Moscow-faction" and the "prison-faction". As the Communist Party was banned in Royal Romania between 1924 and 1944, the "Moscow faction" was formed largely of exiles who managed to leave the country and spend the 
back to their home-country after Romania's armistice with the USSR in 1944. The "Moscowfaction", as they became known, was slowly but gradually challenged by the remnants of the "prison faction" under the leadership of Gheroghe Gheorghiu-Dej. By the late 1950s, GheorghiuDej consolidated his grip on the party, secured the Soviet Army's total withdrawal from Romania and finally successfully embarked on Romania's independent industrialization program against Soviet directions.

These independent policies of the Ghiorghiu-Dej government in the 1950s and 1960s continued and even developed with the advent of Nicolae Ceausescu. Ceausescu's autonomous path climaxed with his notorious refusal to assist the USSR in its invasion of Czechoslovakia in 1968 , based on the notion that each nation should be free to pursue its own path towards socialism. This was of course foreshadowing Ceausescu's own ambitions to 'pursue his own path to socialism' independently from the Soviet Union's watchful eye over its Eastern European satellites.

In order to legitimize this position at home, Ceausescu spiced up this stance with an overt anti-Russian message, on the correct speculation that the perceptions of Russia and implicitly of the Russian-led Soviet Union as an expansionist empire as well as memories of the loss of Bessarabia $^{31}$ were still fresh in the collective mind of the Romanian populace. The nationalist tone changed however somewhat in the latter part of Ceausescu's regime as it started to

bulk of the inter-war years in Moscow rather than at home. They were increasingly opposed by the "prison faction", so called because their leaders were home-grown rather than Soviet-trained and spent the inter-war period in prison. The former were generally more favoured and trusted by the Soviet leadership. The latter because of their rivalry with the "Moscow-faction" became increasingly anti-Soviet and advocated pro-industrialization rather than following directives from Moscow, making them ultimately more prone to adopt an independent Romanian policy from that of the USSR.

${ }^{31}$ Bessarabia, corresponding roughly to the present Republic of Moldova, was the eastern half of the Romanian medieval principality of Moldova. It was annexed by Tsarist Russia in 1812 as well as by the USSR in 1940, reinforcing therefore the perception of Russia as a constant invader in the minds of those annexed as well as those in the rest of Romania. Ceausescu would in fact often cite Marx's pleas to the Tsarist government to 'return Bessrabia to the Romanians' as a means of combining Romanian nationalism and irredentism with the most recognized and respected communist figure, creating ultimately a nexus between Marxism/Communism and Romanian nationalism. 
emphasize an anti-Hungarian message instead of an anti-Russian one. This suggests an attempt by Ceausescu to strengthen his legitimacy and authority by transforming the image of the other from an outside invading force to an internal one, analogous to a fifth column which by implication is more dangerous and more threatening to the existence of the state ${ }^{32}$. This official attitude remained with Ceausescu until the day of his trial, when he cried out "this [the 1989 Revolution] is the work of fascists and irredentists in Transylvania; they want to break up the country". No country in the Soviet Block went as far as to continuously mix nationalism with communism in official doctrine from an early period as in the Romanian case. The only possible exception is Bulgaria which also witnessed a combination of the two, although the communist leaders here did so much later than their Romanian counterparts and for completely different reasons.

In Bulgaria, the communist party under Zhivkov behaved completely opposite to the Romanian leadership. While the Romanian communists wanted their independence, the Bulgarians went out of their way to please Moscow. They faithfully followed Soviet directives, joined the USSR invasion of Czechoslovakia unlike Romania, and generally stuck to the Soviet economic planning for their country without dreaming of alternative native directions which would conflict with Moscow.

However, albeit the fact that Bulgaria was a loyal Soviet ally and never tried to pursue its own foreign policy nor its own path to socialism, Bulgarian communism was marked by a similar kind of nationalist flavor under the latter years of Zhivkov's regime. The reason was not due to the need to legitimize an independent policy to its own population such as in the Romanian case, but rather due to the perception among Bulgarian communist elites that the

\footnotetext{
${ }^{32}$ Michael Shafir, "Marginalization or Mainstream? The Extreme Right in Post-communist Romania", in The Politics of the Extreme Right: From the Margins to the Mainstream, Paul Hainsworth, (New York: Pinter, 2000), 215.
} 
ethnic make-up of the country was threatened by a higher fertility rate among Roma and Turks than among ethnic Bulgarians. This resulted in a much more systemized and organized government effort to reverse the trend which manifested itself through a nationalist policy that was significantly more aggressive than in Ceausescu's Romania.

Alongside a government-led cultural drive to promote 'Bulgarianess' by encouraging nationalist themes in the cinema, theater and literature, the Politbureau embarked on "the revival process", a government program aimed primarily at assimilating Turkish Bulgarians. The policy translated into an organized attempt at erasing Turkish culture and Turkish-Muslim identity through the demolition of Mosques and Turkish-language schools, the confiscation of Turkish books and national costumes, the changing of Turkish names into Bulgarian ones as well as the prohibition of the Turkish language in public. All this was accompanied by forceful arrests and sometimes even executions of those that resisted or hesitated to submit to the assimilation processes. "The revival process" culminated in 1989, just months before change came to Eastern Europe, when over 300,000 Turkish Bulgarians were forcefully driven into Turkey by Bulgarian militias and regular army units in an effort to diminish and weaken the presence of the Turkish minority in the country ${ }^{33}$.

Although Bulgarian communist-nationalism which culminated with the ethnic cleansing of 1989 was much more violent and went much further than its Romanian counterpart (which for the most part limited itself to finger-pointing), similar themes can be distinguished in the two cases. Both Bulgarian and Romanian communist elites have embarked on efforts to demonize their respective major minorities in order to solidify their own position and legitimacy as representatives of the dominant ethnic group within their respective state. By doing so, both

${ }^{33}$ John D. Bell, "The Radical Right in Bulgaria", in The Radical Right in Central and Eastern Europe Since 1989, Sabrina P. Ramet and Roger Griffin, (State College: Pennsylvania State University press, 1999), 243. 
played on the population's collective memory of historical victim ${ }^{34}$ in relation to the Hungarians in the case of the Romanians and Turks in the case of the Bulgarians. The policy was one that created the perception of an attack from within thus raising the need to consolidate the solidarity among the members of the majority under the leadership of the communist party. Notably enough, Bulgaria and Romania were the only countries in the Soviet bloc that witnessed such policies and therefore they represent the only states that could have experienced the consequences of such policies once democratization and liberalization set in.

Poland, the only other Eastern European state where communists did flirt with nationalism, saw sporadic and irregular outbursts of anti-Semitism from communist regimes in 1968 and 1981 upon the introduction of martial law. Although deep rooted in pre-WWII Polish anti-Semitism, these outbursts however were short-lived, at least at the official party level, while being instead increasingly taken up by the Catholic Church following $1981^{35}$. Consequently, one cannot attribute anti-Semitism in post-communist Poland solely to the Polish Communist Party. Furthermore, the emergence of a homogeneous Poland after WWII as a result of the Holocaust, the subsequent expulsions of the Germans and the incoming refugees from Soviet-annexed Galicia, proved a problem for the radical-right as the other, be it the Jew or the German, could no longer be identified and pointed out to the rest of the population. Consequently, the lack of a consistency in the nationalist outbursts of the communist party as well as the disappearance of a plausible scapegoat made the appearance of communist-nostalgic radical right parties in Poland impossible. Moreover, Polish radical right has generally done poorly in Poland as it was also

\footnotetext{
${ }^{34}$ The collective memory of the historical victim was the overlaying theme often emphasized alongside the image of the other as the fifth column. It lies in the second-citizen status of Romanians in Transylvania under Hungarian rule and the 'Bulgarian Horrors' of 1878 at the hands of Turkish irregulars in what was then the Bulgarian provinces of the Ottoman Empire. Communist elites in both countries as well as the radical right after 1989 have made references to these events in their discourse.

${ }^{35}$ David Ost, "The Radical Right in Poland", in The Radical Right in Central and Eastern Europe Since 1989, Sabrina P. Ramet and Roger Griffin, (State College: Pennsylvania State University press, 1999), 92.
} 
handicapped by a poor organization, poor leadership as well as the failure to come up with a consistent economic program ${ }^{36}$.

Consequently, the party systems that emerged in Bulgaria and Romania after 1989 had, as a result of this bizarre feature in their communist past, a vacuum forming at the socialistauthoritarian (and nationalist) end of the political spectrum that simply did not exist in other CEE countries. While in most states, the left was filled by the newly reformed communist parties which now reinvented themselves as socialist-democrats, the Romanian and Bulgarian cases allowed for this space to be so large as to allow for the formation of parties that besides the economically leftist and anti-reformist ticket also picked up the nationalist-communist message of pre-1989 politics.

In other words, while the western radical right was on the right of the spectrum on economic as well as social issues, the Bulgarian and Romanian radical right after 1989 was not a radicalism of the right at all. Its redistributive, communist-nostalgic and anti-reform message would in fact qualify it as a radical left, although such parties have always rejected this label.

At this juncture it is important, however, to point out that this communist-nostalgic form of extremism was not the only one that emerged after 1989. Following the fall of Communism, the radical extremist xenophobic message was adopted by a plethora of parties, not all of them corresponding to the definition outlined above.

In the years immediately after 1989 , two forms of radical right parties of the past actually emerged. One of radical continuity and one of radical return. Radical continuity parties are those described so far, that is to say they are the ones that inherited the nationalism of the communist ideology within their respective countries. They are xenophobic but praise the

\footnotetext{
${ }^{36}$ David Ost, "The Radical Right in Poland", in The Radical Right in Central and Eastern Europe Since 1989, Sabrina P. Ramet and Roger Griffin, (State College: Pennsylvania State University press, 1999), 107.
} 
communist past and its achievements, usually replacing the words "socialist accomplishments" with "national accomplishments"37.

On the other hand, radical return parties are those that call for a return to the far right of the inter-war years. While other countries did not have the extremist parties of the radical continuity type to the extent of Bulgaria and Romania, some did have parties of radical return. However, as it will be explained below these were largely unsuccessful and for this reason they will be excluded from this study.

Being split from the inter-war years by a Communist era which is generally deemed to be a mere interruption of their normal development, parties falling under the radical return category, look towards the distant period before the war as a means of continuing from where the country left off. Radical return exists in almost every Eastern European country yet parties emphasizing just radical return have not been that successful in making it into parliament, with the possible exception of the Slovak National Party (SNS). In essence, the parties of radical return seem to highly resemble Kitschelt's neo-fascists both in ideology, constituencies as well as lack of success ${ }^{38}$.

The failure of radical return is also due to the Communist authoritarian rule and its successful elimination of past extreme nationalist elites during the 1945-1989 period, making room therefore for a communist resurrection of nationalism. As a result, the argument made is based on path dependency since ultimately, wherever communist elites managed to create strange hybrids between Marxist-Leninist ideology and excessive patriotism, post-communist

\footnotetext{
${ }^{37}$ Michael Shafir, "Marginalization or Mainstream? The Extreme Right in Post-communist Romania", in The Politics of the Extreme Right: From the Margins to the Mainstream, Paul Hainsworth, (New York: Pinter, 2000), 250-251.

${ }^{38}$ Ibid, 214.
} 
political systems were prone to have strong parties of radical continuity such as in the case of Bulgaria and Romania. By contrast, wherever communists did not adopt the nationalist card so vividly such as in the rest of CEE, the radical right after 1989 could not be picked up by those opting for radical continuity, while those right-wing politicians, who chose radical return, failed as well since the traditional supporters and ideologues of the latter have been eliminated under the authoritarian communist regimes.

As previously mentioned, the only major exception to the failure of radical return is the Slovak National Party (SNS). Glorifying the fascist WWII-era Slovak state and its leader Josef Tiso, the SNS have made anti-Semitic, anti-Czech ${ }^{39}$, anti-Hungarian and anti-Roma messages part of their platform. The party has likewise combined populism with corporatism to varying degrees of success winning between $5 \%$ and $13 \%$ of votes in Slovak general elections since $1990^{40}$. This is, however, a unique case in the Eastern European Party family as it is the only one where party success can still be observed despite the exclusive radical return message. Similarly to the Romanian and Bulgarian cases, legacy is also what may account for the uniqueness of the Slovak SNS as well. Slovakia's only other experience as an independent country during World War II under a fascist government may have some contribution to the popularity of the Slovak National Party. It is precisely this experience that stands in strong contrast to the experience of nationalist-communism in Romania and Bulgaria which led to the emergence of radical (communist) continuity parties in these two states.

\footnotetext{
${ }^{39}$ The anti-Czech message was emphasized in the early 1990s, primarily due to an association between the Czechs and the increasingly unpopular federal government of Czechoslovakia. This message has increasingly faded away as the issue was no longer relevant after the velvet divorce.

${ }^{40}$ Frank Cibulka, "The Radical Right in Slovakia", in The Radical Right in Central and Eastern Europe Since 1989, Sabrina P. Ramet and Roger Griffin, (State College: Pennsylvania State University press, 1999 ), 118.
} 


\subsection{PRM and ATAKA}

The radical continuity of post-1989 radical parties is obvious when analysing the dogma, party program as well as the personalities of their leaders. A few elements are vividly present in both the Romanian as well as the Bulgarian radical extreme parties, namely the Greater Romania Party (PRM) and ATAKA.

Both are characterized by an authoritarian message and rejection of liberalism. Moreover, the demonization of the other is central in their message, much like their counterparts in the West. Unlike the Western parties however, the other in Eastern Europe can take on many forms and can be adapted to any given situation. In other words, while the other in the West is onedimensional and usually refers to the immigrant, the other in this case reflects the history and legacy of these countries. Two major such forms of the other are reoccurring in both Bulgaria and Romania. One is the minorities which are the best analogous replacement of the immigrants in Western Europe; the second represents the other political parties. Both are demonized and presented as public enemies to the interest of the majority.

Specifically, the demonization of the other in the ethnic sense is done by an official promotion of "national values" representing the main ethnic group rather than the population as a whole. This aspect becomes obvious in the discourse of leaders of PRM and ATAKA which has often been xenophobic and intolerant of the same three groups: Gypsies, Jews and the major minority in each respective country, that is to say Turks in Bulgaria and Hungarians/Magyars in Romania. The image of the other which in Western countries is dominated by the immigrant, is here taken up by the minority. This is obvious given the lack of the former in Eastern European states. 
The demonization of the other parties, on the other hand, takes place through the economic-related discourse of the radical extreme right. Therefore, in the economic sphere, both Romanian and Bulgarian radical right parties reject reform and the capitalist system in its present form and point out to the pre-1989 era as a period that brought security, direction, stability, economic prosperity and safety to the population. This message is not done covertly but rather overtly.

Moreover, the leaders of both parties are not making it a secret that they were ex-cadres or at least close to the Communist regime and that they long for the period prior to the democratization and liberalization of their countries. The nostalgia for the communist past as well as well as their affiliation with it is linked to a general criticism of the high costs of reform for certain strata of society to which these parties are particularly attempting to speak to ${ }^{41}$. Nevertheless, it is important to point out that although the nostalgia has remained a constant, the position vis-à-vis the economy has changed somewhat over time from a total denunciation of all post-1989 reforms in the early 1990 s by PRM and ATAKAs predecessors to a gradual acknowledgement that a total return to socialism is unrealistic but that some of the reforms must be revisited.

Similarly, both parties advocate for less reliance of the IMF and World Bank, institutions considered foreign and hostile to the "national interest". Consequently, PRM and ATAKA are staunch defenders for a Romania for Romanians and a Bulgaria for Bulgarians, not only in the

\footnotetext{
${ }^{41}$ T. Beichelt and M. Minkenberg, "Explaining the Radical Right in Transition: Theories of Right-Wing Radicalism and Opportunity Structures in Post-Socialist Europe" Working Paper (2002): 3.
} 
simple ethnic term mentioned above but also in economic terms as well, asserting that native businessmen and native enterprises should be favoured over foreign ones ${ }^{42}$.

Related to their stance in the area of economics, both PRM and ATAKA seem to point out to the disadvantages of reform not just due to the evidently high costs of liberalization and democratization but also due to the corruption of the mainstream parties and their leaders, blaming them in general for depriving the population of its natural wealth and resources and "betraying the national interest". Consequently, the Romanian and Bulgarian radical right parties do not view post-1989 politics as a battle between left and right like in the Western European states do but rather they consider all other party elites to be in fact a strongly-knit Mafia group which ultimately, despite public declarations, has in fact one single interest and that is to accumulate capital in the detriment of the constituencies they are supposed to serve. This ultimately, leads PRM and ATAKA to reject their positioning on a left-right political spectrum which they consider irrelevant and inapplicable in their countries. Instead, both parties present themselves as the true representatives of the interest of the citizenry regardless of left-right orientations - in contrast to the other parties which are by comparison acting against their interest.

This is obviously a simplified model of the two parties and small nuances do exist between ATAKA and PRM such as a complete demand to exit NATO on the part of the former or an implicitly irredentist message on the part of the latter. However, in general, one can conclude that the same themes above can be said to exist in both the Bulgarian as well as Romanian radical right immediately after 1989 and well into the first half of the current decade,

42 "20 Principles of Ataka Political Party," ATAKA Political Party, 2009, available from http://www.ataka.bg/en/index.php?option=com_content\&task=view\&id=14\&Itemid=27. Internet; accessed 3 April 2009. 
indicating ultimately a direct link between the history of the communist party in these two states and the radical extreme parties that emerged after. Most importantly, both parties overtly recognize the large emerging post-1989 constituency formed of individuals either close to or favoured by the previous regime, which did not gain from the liberalization and democratization of the 1990s. Both ATAKA and PRM do not hide the fact that it is precisely these groups which they try to speak to.

\subsection{Radical Right in the post-1989 Party System}

Before understanding the emergence and presence of the radical right in Eastern European states, it is important to have a glimpse into the party system that emerged in CEE after the anti-Communist revolutions.

Post-1989 Eastern European party systems were, due to the historical circumstances of the region, significantly different from their Western European counterparts. Political competition therefore did not adhere to Lipset and Rokkan's Western European model of the four sets of cleavages: centre - periphery, state - church, rural - urban and employers versus employees $^{43}$. In the latter, the cleavages have emerged gradually over time. This is because they did so in an environment where parties were strongly institutionalized and had the necessary timeframe to renegotiate the rules of the game and address new challenges ${ }^{44}$. The former Eastern European parties were on the other hand catapulted in a political competitive environment that

\footnotetext{
${ }^{43}$ Lipset and Rokkan, Party Systems and Voter Alignments: Cross-National Perspectives (London: The Free Press, 1967), 50.

${ }^{44}$ Nick Sitter, "Cleavages, Party Strategy and Party System Change in Europe, East and West", in Pan-European Perspectives on Party Politics, Paul Lewis and Paul Webb, (Boston: Brill, 2003), 188.
} 
was marked by a tabula rasa due to the authoritarian monopoly on political discourse by the Communist party for forty years prior.

Having clarified this, the cleavages that emerged however cannot be attributed to and are under no circumstances the result of the Communist induced tabula rasa; they were strongly. related to the Communist past of these states. Kostelecky identifies two main features related to cleavages in CEE. Firstly, societal cleavages are multidimensional or cross-cutting - much more so then in Western Europe ${ }^{45}$. This makes the above-mentioned delineation rather inapplicable in Eastern Europe. Secondly and most importantly, a critical cleavage in the East that is not as significant in the West is age ${ }^{46}$. Specifically, this divergence exists between the older generation which has experienced life under communist rule and the younger generation which has either not shared that experience, either experienced the latter part of communism when the cracks of the system were becoming more obvious. As a result, this younger generation is the one more prone to vote for parties advocating reform and a general break with the communist past.

Consequently, the parties that have emerged can be grouped into four categories: 1) communist-reformed social-democratic parties, 2) new parties born out of opposition movements, 3) interest-oriented historical parties and finally, 4) populist parties ${ }^{47}$. The first two have proved to be the best candidates for catch-all parties rather than the latter two. Likewise, both party types have managed to appeal to different political generations; while the older voters in Romania and Bulgaria ${ }^{48}$ have opted for left-leaning politics and the social-democrats, the

\footnotetext{
${ }^{45}$ Kostelecky, Political Parties After Communism: Developments in East-Central Europe (Washington: Woodrow Wilson Center Press, 2002), 107.

${ }^{46}$ Ibid, 114.

${ }^{47}$ Nick Sitter, "Cleavages, Party Strategy and Party System Change in Europe, East and West", in Pan-European Perspectives on Party Politics, Paul Lewis and Paul Webb, (Boston: Brill, 2003), 188.

48 Vladimir Shopov, "How the Voters Respond in Bulgaria", in Cleavages, Parties, and Voters: Studies from Bulgaria, the Czech Republic, Hungary, Poland, and Romania, Kay Lawson et. al. , (Westport: Praeger, 1999$)$, 193.
} 
younger ones have voted for the pro-reformist parties ${ }^{49}$. Having mentioned this, it is important to point out that these groups are by no means exclusive and elements of two or more of the abovementioned four categories may be found within one single party.

Examples of the first category that captures the generally older voters (communistreformed social-democratic parties) are the Bulgarian Socialist Party (BSP) in Bulgaria and Social-Democratic Party (SDP) in Romania but also the Hungarian Socialist Party, Polish Alliance of the Democratic Left and the Czech Social Democratic Party. Consequently, this category is prevalent in all post-Communist Eastern European states and is by no means exclusive to Bulgaria and Romania.

Interestingly enough, while the first category has had the monopoly on the post-1989 left, the centre-right (popular with the younger generations) has been shared between the new parties born out of opposition movements and the historical parties. The new parties include the Union of Democratic Forces (UDF) in Bulgaria and the Democratic Party as well as the former Romanian Democratic convention. These correspond to the Civic form in the Czech Republic or the Freedom Union in Poland. The historical parties are represented by the National Liberals and Christian-Democratic Peasant Party in Romania and the National Movement Simeon II in Bulgaria. Christian-Democratic parties in the rest of CEE are also members of this category. Therefore, similarly to the first category, examples of the second and third party-family are present throughout CEE.

The fourth and last category of populist parties is the most relevant for the purpose of this study as it includes radical and nationalist-extremist parties. Populism, however, is not limited to this party family and in fact can be observed among other mainstream parties as well. This is in

49 Petre Datculescu, "Patterns of Voter Alignments in Present-Day Romania", in Cleavages, Parties, and Voters: Studies from Bulgaria, the Czech Republic, Hungary, Poland, and Romania, Kay Lawson et. al. , (Westport: Praeger, 1999), 270. 
part due to a limited and weak institutionalization that has allowed for a dependence on leadership and leadership charisma rather than party organization ${ }^{50}{ }^{51}$. Populism albeit being only sometimes present and indeed a requirement for the success of the mainstream parties, is nevertheless a crucial, if not the most crucial, ingredient for the radical extremists. This element becomes vivid after a quick glimpse into the performance of the radical extreme right in post1989 elections.

Both the main radical extreme parties in Romania and Bulgaria, PRM and ATAKA respectively, have benefited from strong, authoritarian charismatic leaders who often displayed an overtly xenophobic and flamboyant attitude in public as well as in private. In retrospect, the lack of such a leader has had a significant impact in Bulgaria where albeit the demand for such a party existed, the lack of adequate supply through a strong leadership has resulted in the absence of the radical right from parliament.

PRM has formed almost immediately after the 1989 Romanian Revolution and achieved relatively modest yet stable results between 1992 and 2000. Although the popular vote achieved was often around $4 \%$, the party has managed to enter parliament and on several occasions even succeeded in becoming the junior partner of the Social-Democrats alongside other similar yet short-lived and smaller communist-nostalgic radical right parties such as the Party of Romanian National Union (PUNR) and the Socialist Labor Party ${ }^{52}$. The early consolidation of the party as well as the formation of the other two can certainly be attributed to an almost immediate perceived high cost of transition but most importantly this perception which translated into

\footnotetext{
${ }^{50}$ P.G. Lewis, "Democratization and Party Development in Eastern Europe", Party Politics 1(3)(1995): 393.

${ }^{51}$ P.G. Lewis, Political Parties in Post-Communist Eastern Europe (London: Routledge, 2000), 25.

52 "Historical Archive of Parliamentary Election Results in Romania," Inter-Parliamentary Union, 2009, available from http:/www.ipu.org/parline-e/reports/2262_A.htm. Internet; accessed 3 April 2009.
} 
voters' demand was skillfully exploited by PRM leader Vadim Tudor. Therefore, Tudor used his charismatic leadership to capitalize on the vacuum formed after 1989 almost immediately. The president of PRM quickly used his personality to organize the party in Bucharest as well as throughout the country, making it by 1992 a serious actor in Romanian politics. Consequently, between 1992 and 2004, PMR has been present in every Romanian Parliament. He has likewise used his party's superior organization and personal charisma to assimilate the smaller PUNR and Socialist Labor Party into the PMR by the mid 1990s, consolidating therefore the radical-right supply within his own party.

In Bulgaria, events did not occur quite in the same manner. This is not because the same vacuum did not exist there right after 1989 but rather because a plethora of parties shared that space without one clear significant leader who could assume the charisma and personality of Corneliu Vadim Tudor. Therefore, between the 1990s up until 2005, several parties competed for the radical extremist yet Communist-nostalgic electorate. They were the National Movement for the Salvation of the Fatherland (Natsionalno Dvizhenie za Spasenie na Otechestvoto), the Bulgarian National Patriotic Party (Bălgarska Natsionalna-Patriotichna Partiya) and the Union of Patriotic Forces and Militaries of the Reserve - Defense (Săyuz na Patriotichnite Sili $i$ Voinite ot Zapassa - Zashtita). All three were in essence miniature versions of the PRM. Neither of them managed to attain more than $1.5 \%$ of popular votes while only one has managed to win a single seat in the Bulgarian National Assembly ${ }^{53}$. Moreover, the nationalist message was likewise taken up by the mainstream socialist party (the ex-communists) which briefly even allied themselves with a fringe-ultranationalist party, Fatherland Party of Labor ${ }^{54}$. This made it

${ }^{53}$ John D. Bell, "The Radical Right in Bulgaria", in The Radical Right in Central and Eastern Europe Since 1989, Sabrina P. Ramet and Roger Griffin, (State College: Pennsylvania State University press, 1999), 245.

${ }^{54}$ Maria Spirova, "The Bulgarian Socialist Party: The long road to Europe," Communist and PostCommunist Studies 41(2008): 488. 
harder for other parties, akin to the Greater Romania Party in Romania, to fill in the nationalistcommunist space.

The year that marked the crucial change in that country's party system was 2005 , when Volen Siderov, a popular TV host, created his own party: Partya ATAKA ${ }^{55}$ and together with the former three joined to form the National Union Attack, first a coalition of parties and later on a party in its own right, now known as ATAKA. The party has managed to win $9 \%$ in the 2005 elections and has remained stable at these levels years after. In the 2006 presidential elections Volen Siderov was the runner up against Bulgarian incumbent and gathered over $21 \%$ of the votes.

The late arrival of the charismatic Volen Siderov in Bulgarian Politics retarded the success of the communist-nostalgic right of the past, but by no means did it delay its appearance. It already existed as early as the 1990s much like in the Romanian case. Ultimately, Volen Siderov, being a TV host and benefiting already from years of accumulating a loyal and stable audience, has managed through his entrance in Bulgarian politics to transplant his TV audience and transform it into a political constituency that has been quite loyal to Siderov and his ATAKA party since 2005 .

In this respect Siderov, due to the nature of his very profession, has benefited from a much more effective platform for spreading his message than his Romanian counterpart Vadim Tudor. While the latter had to depend on the party's newspaper and the occasional invitation from TV stations where he could release his ostentatious personality, Siderov had the opportunity to make himself known for years prior to his decision to form ATAKA. Consequently, the populist Siderov as well as his party's populist message was significantly

${ }^{55}$ ATAKA was the name of Volen Siderov's show, name which he kept for the new party as well, indicating Siderov's own recognition of the strong relationship between the personality and popularity of leader and the party. 
better marketed than that of the Greater Romania Party. The association of his name with ATAKA makes his personality a crucial factor in the party's success.

Siderov's late arrival compared to Vadim Tudor's early rise is not the only reason for PRM's longevity vis-à-vis ATAKA's recent appearance. Institutional constraints in Bulgaria have certainly been responsible for this feature as well. These constraints are largely in the form of electoral rules which have affected the performance of these parties. While Bulgaria's threshold was 4\% and later 5\%, Romania's threshold was 3\% in the 1992 elections as well as the 1996 elections $^{56}$. Therefore, while PRM's performance during these elections hovered between $3 \%$ and $4 \%{ }^{57}$ similar to the Bulgarian Radical Right parties during the same period of time, the party was nevertheless still able to make it to parliament, albeit if just by barely fulfilling the required percentage of votes.

Consequently, while the demand for these parties was strong in both countries, it is party organization and leadership as well as institutional constraints that played the determining role in the consolidation of the communist-nostalgic radical right and its performance in these two states.

\subsection{Conclusion}

In conclusion, the radical right in Eastern Europe has developed quite differently from their counterparts in Western Europe in the early years following the fall of communism. Two

\footnotetext{
56 "Lege nr. 68 din 15/07/1992 pentru alegerea Camerei Deputaților și a Senatului, Publicat in Monitorul Oficial 164(1992)," LegeStart, 2009, available from http:/www.legestart.ro/Lege-nr-68-din-1992-(MTY5MjA-).htm. Internet; accessed 3 April 2009.

57 "Romania Parliamentary Chamber 1992 Elections," Inter-Parliamentary Union. 2009. Available from http://www.ipu.org/parline-e/reports/arc/2262_92.htm. Internet; accessed 3 April 2009.
} 
general forms of radical right parties can be said to have emerged in Eastern Europe after 1989. One evoked the fascist past of the inter-war period such as the case of the SNS in Slovakia, the only such successful example in this category. The second, more successful, was the radical right of the communist past.

Both ATAKA as well as Greater Romania Party can be said to belong generically to this latter category of radical extreme parties. Specifically, they are both characterized by an authoritarian, anti-liberal, anti-capitalist message coupled with a common nostalgia and overt association with the previous Communist regimes in response to the perceived high costs of transition in both states. Moreover, both have created a multi-dimensional image of the other. One such dimension takes the form of national minorities much like the Romanian and Bulgarian communist parties. The second consists of the other political parties, both of with are depicted as enemies and traitors to the state.

Secondly, both ATAKA and Greater Romania have depended on their leadership for their success. Both have risen to prominence when a charismatic leader has made himself available to represent - and for all purposes - be the image of the party in the respective states. While Greater Romania Party was more fortunate to have had Corneliu Vadim Tudor in the early 1990s, ATAKA has achieved a similar success with the arrival of TV host Volen Siderov. In essence, both men, stirring similar sentiments of nostalgia, have had a monopoly on the radical right vote in their respective states in the early 1990 s as well as early 2000 s. This is somewhat similar to radical right parties in Western Europe where leadership plays a crucial role. Examples of this in the west are Haider of the Austrian Feedom Party and Jean-Marie Le Pen of the French National Front Party. 
Finally, both the Romanian as well as the Bulgarian communist-nostalgic radical right have been greatly impacted by the institutional constraints of these states. Features of electoral law, such as higher thresholds, have proven to be a serious impediment in the case of the Bulgarian radical right or retrospectively, due to the smaller threshold required to enter parliament, an important asset for the Greater Romania Party. Ultimately, the well-organized, unified PRM under the charismatic Vadim Tudor combined with the low thresholds of the 1990s can be attributed to the success of Greater Romania Party while similarly relatively higher thresholds, the lack of radical right unity as well as the lack of leadership or well-defined and clear programs until 2005 are the principal obstacles to the success of the radical right in this country.

This however is not a complete picture of the radical right of the communist past and its evolution after 1989. In the following chapter, the role of marketplace regulators outside electoral rules (such as the European Union and EU conditionality) will be explored in order to capture the effects that external influences have had on the demand and supply of mainstream parties within these states and most importantly for the purpose of this study, the effects that this rearrangement of the demand and supply has had on the radical right. 


\section{Chapter 4}

\section{The EU and the Radical Right in Romania and Bulgaria}

The Bulgarian State is obliged to provide proper conditions for health, social security, spiritual and material prosperity of all Bulgarians by all means of the State power. Every Bulgarian investor, undertaker and producer has priority over all foreign ones until Bulgarians' living standard reaches the average level of the European Union. Bulgarian production, commerce and the banking system should be in Bulgarian hands. Taxes and incomes in Bulgaria must be set according to the financial capacity and the needs of Bulgarian citizens and not according to the requirements of the International Monetary Fund and the World Bank. Leaving NATO. Rejection of Bulgarian dependence on the International Monetary Fund and the World Bank.

Excerpt from the 20 Principles,

ATAKA Party (2005)

\subsection{Introduction: Romanian and Bulgarian Radical-Right}

Following the 1989 revolutions, Central and Eastern European (CEE) states embarked on policies of reform and democratization. In terms of foreign policy, joining NATO and the European Union became overriding aspects. Despite their slower and clumsier process towards

\footnotetext{
58 "20 Principles of Ataka Political Party," ATAKA Political Party, 2009, available from
} http:/www.ataka.bg/en/index.php?option=com_content\&task=view\&id=14\&Itemid=27. Internet; accessed 3 April 2009 . 
accession, Romania and Bulgaria were not exceptions to the regional trend. With the realistic prospects of EU integration came however a series of factors that significantly altered the politics within these states. Primarily, mainstream parties (including the originally reluctant socialdemocrats) realized the importance in speeding up accession and complying with EU norms and requests especially given the rapidly increasing public awareness and opinion favoring EU accession after the mid-1990s. Over time therefore, parties altered their message to comply with the new interests of their national constituencies.

Secondly, for the purpose of this study, the radical right was left in a crucial position in the political space of Romanian and Bulgarian politics. The ever increasing prospect of integration during the 2000 s altered the demand-side for such parties as voter preferences began to change. Faced with EU conditionality as well as the increasing popular demand for EU membership, mainstream parties had to move towards the centre-right of the political spectrum and effectively embark on institutional, economic and judicial reform. This attitude was likewise taken up by the former communists who also moved from the left towards the centre. However, by doing so, the former-communists strengthened the position of the radicals in both states which consequently became almost sole occupants of the far-left political space. As explained in the previous chapter, although the radical right occupying the far-left political space might seem as an oxymoron, the radical right parties in Romania and Bulgaria during the 1990s and early 2000s have been parties of the left with strong communist legacies due to the unique nationalcommunist past of these states. As a result of this communist-era legacy, the radical-right in the East was thus advocating economically-leftist measures and was speaking to the losers of the 
post-1989 transition rather than advocating the pro-market capitalist measures of their radicalright counterparts in Western Europe ${ }^{59}$.

Ultimately, the effect was a strengthening of the radical right during the 1990s and mid 2000 s, a rise in the far-right vote and subsequently, an increasing presence of the party family in national parliaments. This chapter will illustrate the effects of the EU as an external regulator on the Bulgarian as well as Romanian marketplace and the gradual transformations of the original communist-nostalgic radical right in Romania and Bulgaria as the prospect of EU integration began re-socializing voters in both states.

\subsection{EU Passive Leverage and the Radical Right}

Before the Socialists became centre-left catch-all parties in light of changing voter preferences in the mid-1990s, the years immediately following 1989 were marked by a strong cooperation between the radical-right and the socialist-democrats who shared the same left political space. Being skeptic of reform and market transformations and in light of little EU influence to persuade them otherwise, former ex-communists (now social-democrats/socialists) found the strongly nationalist radical parties natural allies and in the case of Bulgaria where the radical-right was co-opted by the former, the socialists took on the nationalist message themselves. This nationalism (both from the radical-right as well as the Bulgarian socialists) was aimed primarily at the major minority in each respective state and the political parties representing them.

\footnotetext{
${ }^{59}$ For this reason, in this study, the term "radical-right" in Romania and Bulgaria before 2005 will be used to indicate exclusively this brand of radical politics combining nationalism and authoritarianism with economicallyleftist policies.
} 
The collapse of communism in 1989 and the loss of legitimacy of the communist system as well as its economic model resulted in the reorientation of countries in Central and Eastern Europe towards the capitalist model in the west. Although countries embarked on liberalization, democratization and reform at their own pace, some sooner and more effectively than others, no formally Soviet-satellite CEE state pursued a general policy other than "catching up to the West". The "catching up to the West" became necessary as the West provided the only available and therefore possible successful model that the new Eastern European democracies could follow.

Catching up did not only mean achieving the level of development that Western European countries were at but also implied joining them and thus being recognized as legitimately part of them. This was also referred to as "rejoining the European family", implying that CEE countries were always part of the West and only left it temporarily while under the Soviet-imposed communist regimes. Consequently, the two most important western institutions were courted by the newly democratic CEE states. One was the military transatlantic organization NATO, the other - the European Union. While dissimilar in their scope, many Central and Eastern European politicians, and indeed the public at large, saw the accession to the two as interrelated; one could not be achieved without the other. Therefore during the 1990s and early 2000s, governments in Central and Eastern Europe pursued a double-track effort to join both NATO as well as the EU. In fact, this became the foreign policy of CEE states following the revolutions of 1989.

Romania and Bulgaria were laggards in implementing reforms and speeding up the accession process but the commitment to reform and ultimately join the Euro-Atlantic organizations has been, at least officially, always part of the policies of every post-1989 
government as well as at the forefront of any list of promises of every political party, including Romania's Greater Romania Party (PRM). In Bulgaria, only the most obscure, radical and peripheral parties advocated outright rejection of the EU, ATAKA actually supporting it as long as "Bulgarian national interests" were preserved and as long as accession was done on Bulgaria's terms instead of those of the European Union ${ }^{60}$.

The reason for this consensus in both states, despite their strong social-democratic/excommunist parties as well as the communist-era legacy of nationalism, is due to the perceived unbearable costs of not joining. The cost of being left outside the EU, especially while their neighbors were allowed in, was perceived as extremely grave in terms of economic consequences. Money, expertise, and foreign direct investments would be directed towards the new members and away from the outsiders. Trade would likewise suffer as exports to EU members, including their former Central and Eastern European partners (which were about to join the Union), would now be subjected to EU protectionism while agricultural goods would not be able to enter EU markets ${ }^{61}$. Moreover, the accession of their regional partners implies that travel without visa in these formally Soviet-bloc states becomes impaired, especially because given the 2004 accession, states such as Romania and Bulgaria were deprived of many of their former non-EU neighbors with which they previously shared preferred visa regimes ${ }^{62}$.

Joining the EU had therefore irresistible benefits. Besides the reduction in uncertainty, increase in democratic stability, prosperity and collective security, the access to EU markets as well as their ability to have a say in the rules of the game inside the exclusive organization was

\footnotetext{
60 “20 Principles of Ataka Political Party," ATAKA Political Party, 2009, available from http://www.ataka.bg/en/index.php?option=com_content\&task=view\&id=14\&Itemid=27. Internet; accessed 3 April 2009.

${ }^{61}$ Milada Anna Vachudova, "The Leverage of International Institutions on Democratizing States: Eastern Europe and the European Union," Robert Schuman Centre for Advanced Studies 33(2001): 9.

${ }^{62}$ Tom Casier, "The New Neighbours of the European Union: The Compelling Logic of Enlargement", in The Boundaries of EU Enlargement, Joan DeBardeleben, (New York: Palgrave Macmillan, 2008), 21.
} 
perceived as essential in the successful transition from state socialism to market capitalism ${ }^{63}$. Moreover, joining the EU would assist these states in their relations with their more powerful neighbors, both inside the Union due to the rules of the institution itself, as well as outside the union due to the power of collective bargaining. The perceived prosperity and therefore need to join was reinforced by the previous cases of Greece and Portugal, formally less developed European states that prospered due to membership as they saw rapid modernization, access to new markets as well as transfer payments, an especially highly attractive incentive to the Central and Eastern European states.

The attractiveness of the EU was strongly related to its ability to effectively persuade the CEE states that membership was indeed a possibility. This in turn affected the dynamics betweens parties inside these states, including the radical right. The EU's ability to persuade is described by Vachudova as "passive" and "active leverage": passive meaning here the simple attraction of EU membership, while active signifying the deliberate conditionality exercised by the EU during the accession process ${ }^{64}$. The period of the early 1990 s is characterized by the former while after 1995, by the latter. Passive leverage suggests little influence in shaping domestic policies. Passive leverage is especially important for the two countries studied here (Romania and Bulgaria) because during this time, domestic politics were least affected by EU conditionality and mostly shaped by the former communists who in light of a lack of a pushfactor from outside could afford to stir their respective countries towards the left and away from speedy reforms.

\footnotetext{
${ }^{63}$ Milada Anna Vachudova, "The Leverage of International Institutions on Democratizing States: Eastern Europe and the European Union," Robert Schuman Centre for Advanced Studies 33(2001): 7

${ }^{64}$ Milada Anna Vachudova, "The Leverage of International Institutions on Democratizing States: Eastern Europe and the European Union," Robert Schuman Centre for Advanced Studies 33(2001): 4.
} 
In these states, social-democrats or reinvented ex-communists took power early on ${ }^{65}$. Socialists gained $67 \%$ of senate seats in the 1990 Romanian elections and a plurality in 1992 , giving them enough votes to form government until the 1996 elections. In Bulgaria, the socialist party formed the government after all elections between 1990 and 1994, save for a few months of United Democratic Forces (UDF) government ${ }^{66}$. Due to the need to prolong their stay in power, the ex-communist parties managed to foster a fear of reform, therefore resulting in sabotaging the economic development of their respective countries and subsequent earlier EU membership, albeit still paying lip-service domestically and internationally as they reaffirmed their commitment to democratization, liberalization and EU integration. This induced fear of reform was also combined with a nationalist message on the part of the socialists ${ }^{67}$.

As explained in the previous chapter, the Bulgarian Socialist Party (BSP) took up the nationalist rhetoric of the previous communist regime and even allied itself with a fringe radicalright party of the 1990s, the Fatherland Party of Labor. A similar alliance, albeit officially only lasting three months, took place between the Romanian National Salvation Front (later SocialDemocrats) and the Greater Romania Party (PRM) alongside other minor similar radical parties in $1995^{68}$. Cooperation between them in government can be traced even before that year, however.

In essence, the radical right discourse in these states during the period indicated by Vachudova (1990-1995) seems to have been either subtly adopted by the mainstream exCommunist Socialist Party as in Bulgaria or by communist-nostalgic extremists with close links

\footnotetext{
${ }^{65}$ P.G. Lewis, Political Parties in Post-Communist Eastern Europe (London: Routledge, 2000), 31.

66 "Historical Archive of Parliamentary Election Results in Bulgaria," Inter-Parliamentary Union, 2009, available from http://www.ipu.org/parline-e/reports/2045_A.htm. Internet; accessed 3 April 2009.

${ }^{67}$ Milada Anna Vachudova, "The Leverage of International Institutions on Democratizing States: Eastern Europe and the European Union," Robert Schuman Centre for Advanced Studies 33(2001): 4.

68 "Historical Archive of Parliamentary Election Results in Romania," Inter-Parliamentary Union, 2009, available from http://www.ipu.org/parline-e/reports/2262_A.htm. Internet; accessed 3 April 2009.
} 
to the ruling ex-communist such as Greater Romania Party and PUNR in Romania or even the Fatherland Party of Labor in Bulgaria. This seems to support Vachudova's argument that former communists and nationalists cooperated during the early 1990s, scaring the population from accepting economic reform while similarly promoting intolerance towards minorities, reminiscent of the communist-era, as a means of keeping power as well as diverting attention from government mismanagement and corruption ${ }^{69}$.

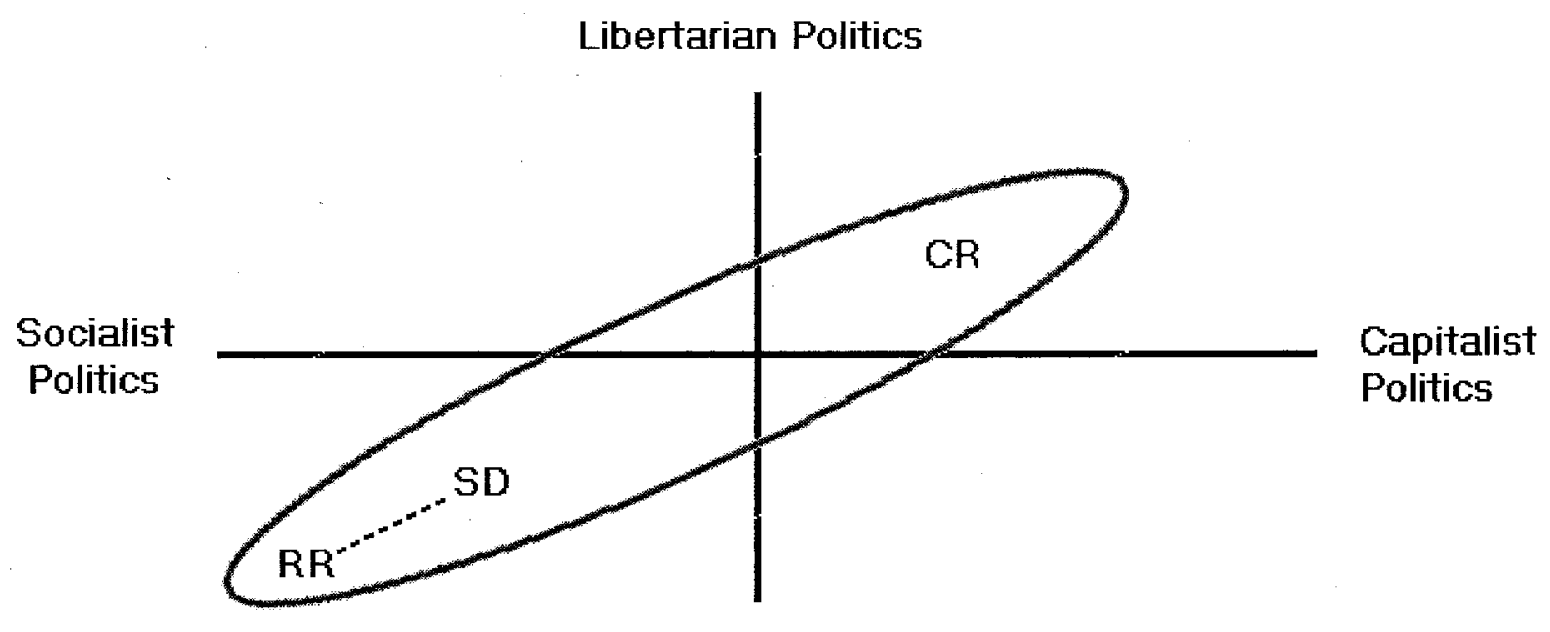

Authoritarian/Nationalist Politics

Graphic Representation Developed by the Author Drawing on Conceptualization Provided by Kitschelt.

Fig. 2 Political Spectrum in Romania and Bulgaria in the Early 1990s. (RR-radical right, SD - Social Democrats, CR - centre-right)

Ultimately, this period can be described as one where the left had significantly more space on the political spectrum due to a less informed public (vis-à-vis the benefits of EU integration) as well as due to socialists' nationalist messages or nationalist political allies distracting public opinion and sabotaging economic and institutional reforms. Fig. 2 draws on the spatial representation employed by Kitschelt when describing the Radical Right in Western

${ }^{69}$ Milada Anna Vachudova, "The Leverage of International Institutions on Democratizing States: Eastern Europe and the European Union," Robert Schuman Centre for Advanced Studies 33(2001): 9. 
Europe, to illustrate the positioning of the radical right party family in Romania and Bulgaria. Unlike the Western European model, where the electorate was positioned along an authoritarian/capitalist versus libertarian/socialist axis ${ }^{70}$, the political space in Bulgaria and Romania is completely opposite associating libertarian politics with capitalism and authoritarian politics with socialism. The competitive space for political power between 1990 and the mid2000s followed therefore a nationalist/socialist versus libertarian/capitalist axis. The centre-right, depicted as CR in Figure 2, represents not just one party but rather the pro-reform parties or coalitions. The social democrats (SD) and radical right (RR) are essentially covering the socialist-authoritarian and nationalist space. The cooperation between them or the nationalist element of the socialists in Bulgaria is depicted here as a dotted line. As previously mentioned, the existence of a communist-nostalgic radical-right on the left of the political spectrum was possible in Bulgaria and Romania, unlike in other post-communist states, due to the pre-1989 legacies in these countries that combined communism with nationalism.

Intolerance was promoted in both countries versus the national minorities previously targeted by the former communist regimes This was especially directed, not just towards the members of the minorities themselves but also towards the new post-1989 generally ethnic-based political parties that emerged in order to represent them.

Intolerance in Romania was encouraged particularly vis-à-vis the Hungarian minority by both PRM as well as PUNR. After the Revolution of 1989, which itself was characterized by trans-ethnic solidarity ${ }^{71}$ against Ceausescu's brutal regime, the inter-war period historical parties 
became part of the new political actors in post-communist Romania; the Magyar Democratic Union of Romania (the successor of the Magyar Party of the 1920s and 1930s) was one of the first ones to form alongside the National Liberals and National Peasants.

The Magyar Democratic Union demanded the reopening of Hungarian universities, the use of Hungarian in public and with public officials, cultural and lastly territorial autonomy. Both PRM and PUNR used this in order to escalate public rage vis-à-vis the prospect of the disintegration or balkanization of the country. Consequently, they used the Hungarian minority (much like Ceausescu did during his time in power) as an image of an internal enemy bent on disintegrating the already economically and politically unstable country from within. Interestingly enough, Greater Romania Party, albeit its irredentist name ${ }^{72}$, has not focused so much on the "Greater Romania" irredentist issue as its name implies but rather concentrated on the anti-Hungarian message. Similarly, after diminishing success in national elections, PUNR has focused on running in the ethnically mixed city of Cluj until its absorption into PRM, playing the ethnic card in local elections as well as in governing the city.

In Bulgaria, the policies of "Revival", mentioned in the previous chapter, were immediately reversed following the transition to democracy and liberalization. The government instantaneously claimed that it would restore the civil rights to ethnic Turks and allow them a three year period in which they could reverse their names ${ }^{73}$. Similar to the Magyar Democratic Union in Romania, a Movement for Rights and Freedoms (MRF), composed largely of TurkishBulgarians of the underground Turkish National Freedom Movement that opposed Zhivkov's

group but rather to Romanians, Hungarians and Germans alike, Germans being at that time the third largest minority in the country.

${ }_{72}$ Partidul Romania Mare (PRM), literally meaning Greater Romania Party uses symbols such as the map of Greater Romania, the inter-war kingdom after the territorial acquisitions following WWI, however the party has rarely focused on developing its irredentist message beyond the symbols it uses and instead has focused primarily on an anti-establishment, anti-Hungarian, anti-Semitic and anti-Rroma message. 1984-1989.

${ }^{73}$ Ethnic Turks in Bulgaria were forced to bulgarize their names during the period of "National Revival" in 
bulgarization, was soon formed with the aim to safeguard the rights of all citizens of Bulgaria regardless of nationality.

Following these events, ethnic-Bulgarian citizens in mixed areas, particularly those who had profited from the nationalist policies of "Revival", protested against the new developments, especially against what they perceived as an exclusive unconstitutional ${ }^{74}$ ethnic party. The precursor of the Fatherland Party of Labor under Mincho Minchev (currently a partner in Siderov's ATAKA) was instrumental in rallying significant numbers of protesters within the ethnically mixed regions of the country ${ }^{75}$.

Despite the similarities between the two countries however, developments in Bulgaria did differ somewhat from those in Romania. While in the case of the latter, the communist-nostalgic extremists held on to their popularity, due in part to the reluctance of the Social-Democrats to overtly use the nationalist card themselves, in Bulgaria, the socialists did precisely just that, thus gradually co-opting and subsequently pushing aside the Fatherland Party of Labor: Essentially, albeit demand for the radical-right existed in both states, the last feature of the reformed/reinvented communists in Bulgaria deprived the right radicals of their political space. Given Bulgaria's slightly higher electoral threshold as well as the lack of a truly charismatic leader until the mid-2000s, radical right parties were left largely outside parliament for the large part of the mid and late 1990s.

Nevertheless, in both states, during the early 1990s, the nationalist message reminiscent of the communist past was combined alongside economically left-oriented policies by either the

74 According to Bulgaria's constitution, no ethnic parties may be allowed to register. The Movement for Rights and Freedoms has circumvented this legislation in that it allows membership to any Bulgarian citizen provided they adhere to the party doctrine promoting equal rights to minorities. In effect, the MRF is largely formed of ethnic Turks.

75 John D. Bell, "The Radical Right in Bulgaria", in The Radical Right in Central and Eastern Europe Since 1989, Sabrina P. Ramet and Roger Griffin, (State College: Pennsylvania State University press, 1999), 245. 
socialists themselves as in Bulgaria or, by radical parties in cooperation with the socialists as in the Romanian case. The demand for this mix between left-oriented economic policies and nationalism existed in both countries from that same segment of the electorate - that is to say, those that did not gain from the 1989 revolutions or from the restoration of civil rights to minorities. Supply however can be seen lacking in one case and abundant in the other; consequently, this case exemplifies that it is not just supply or just demand which ultimately can be considered to be the causes for a successful radical right party but rather the presence of both. As proven here, the supply and the position of the other mainstream parties was a necessary factor despite the strong demand during this period.

\subsection{The Radical Right during EU active-leverage}

After 1995, politics in both countries changed significantly. For the first time in the short post-1989 history of both countries, the social-democrats lost power to centre-right parties. According to Vachudova, this is in great part due to the active leverage exercised by the European Union. Specifically, EUs vocal condemnation of governments that failed to meet EU requirements and were excluded from accession negotiations had an important impact on societal awareness of the benefits of EU membership in laggard-countries. Indeed EU-accession had increasing support, reaching numbers such as $70 \%$ in Bulgaria and even $90 \%$ in Romania ${ }^{76}$. This awareness has translated into dissatisfaction with the ruling party or coalition; ultimately the EU has supplied the prospect of EU membership to emerging moderate centre-right parties, which

\footnotetext{
${ }^{76}$ Dr Vlad Nistor, Romanian Diplomatic Institute - interview conducted in 2008.
} 
could now deliver their message to a much more receptive audience ${ }^{77}$. In essence the EU has greatly helped transform the positioning of the electorate on the Bulgarian and Romanian political spectrum, moving it significantly towards the right on economic issues. What Vachudova does not explain, due to the fact that her focus is largely on EU conditionality, not the radical right, is how the European Union has helped shape the transformations that occurred within this party family in these states after 1995.

In fact, the European Union affected the radical right just as much as it shaped politics between the mainstream parties. Firstly, the greatest impact for the radical right was that due to the EU's increasing condemnation of social-democratic governments in Eastern Europe, the farright was removed from the party in power. This occurred not just because the socialists were removed from power in 1996 and 1997 in Romania and Bulgaria respectively, but also because external condemnation, which until 1995 had little resonance inside these states, was extremely influential in shaping public opinion afterwards. Condemnation of extreme-nationalism has therefore resulted in the desertion of the nationalist undertone of the Bulgarian socialists while similarly leading to the open pledges of the Romanian social-democrats to never again form alliances with $\mathrm{PRM}^{78}$.

Although not the only factor responsible for the success of the radical right, this has had nevertheless significant influence on the performance of these parties. By being detached from the socialists with whom they often cooperated, the radical right was now essentially left on its own. This resulted in the creation of a political space or vacuum that was abandoned by the mainstream left which now could be picked up solely by the radicals.

\footnotetext{
${ }^{77}$ Milada Anna Vachudova, "The Leverage of International Institutions on Democratizing States: Eastern Europe and the European Union," Robert Schuman Centre for Advanced Studies 33(2001): 5.

${ }^{78}$ William Downs and Raluca Miller, "The 2004 presidential and parliamentary elections in Romania," Electoral Studies 25 (2006):412.
} 
Moreover, what EU condemnation of the socialists also did was to induce the need to reform and renovate the socialist image if they were to survive post-1990 politics. In essence, the EU's harsh criticism of the lack of reform, corruption and disingenuous nature of the socialists forced the party-family to transform itself from slow or reluctant reformers to actual committed actors in their respective countries' accession process ${ }^{79}$. It was after all under the SocialDemocratic Party that Romania joined NATO (the other Euro-Atlantic organization) and that Romania opened most negotiation chapters with the EU. Likewise, it was under the Bulgarian socialists that Bulgaria adopted the $10 \%$ flat tax and finally closed the negotiations with the European Union. This move towards the right on the part of the Bulgarian and Romanian socialists has isolated the radical right of the communist-past even further in the left-economic pole of politics. Therefore, whereas prior to 1995 , the ex-communists and radical-right shared the left/communist-nostalgic vote, after 1995 the ex-communists attempt to be a catch-all party, thus leaving the radical right virtually alone on the far left of the political spectrum.

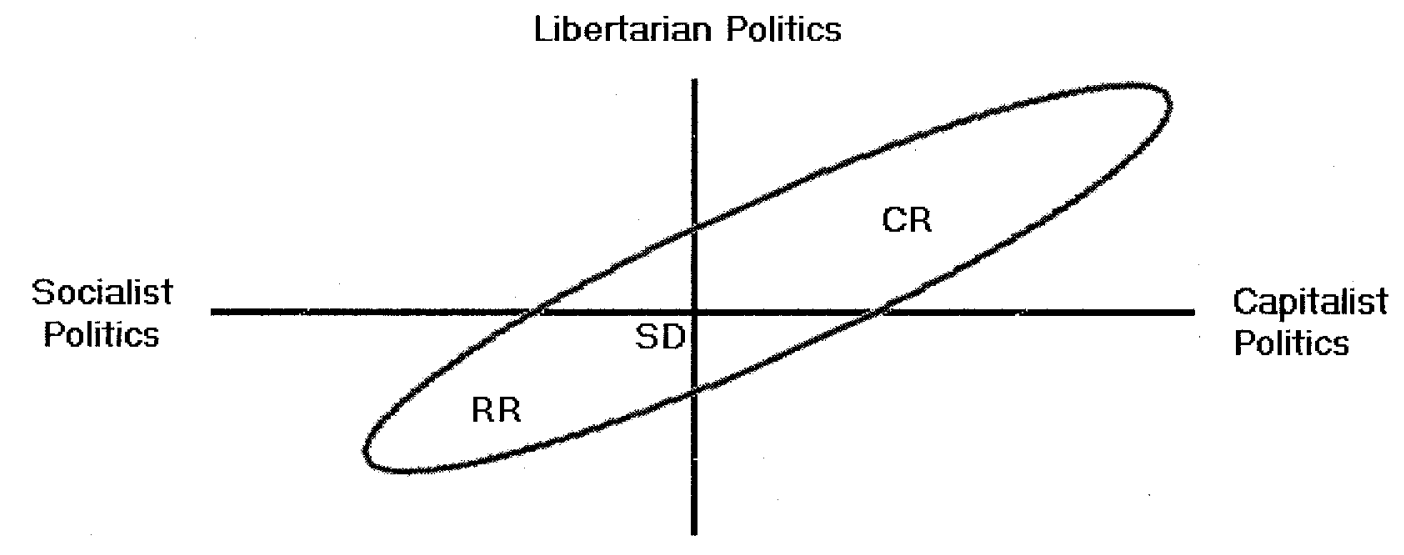

Authoritarian/Nationalist Politics

Graphic Representation Developed by the Author Drawing on Conceptualization Provided by Kitschelt.

Fig. 3 Political Spectrum in Romania and Bulgaria between 1995-2005 (RR-radical right, SD - Social Democrats, CR - centre right)

\footnotetext{
${ }^{79}$ William Downs and Raluca Miller, "The 2004 presidential and parliamentary elections in Romania," Electoral Studies 25 (2006): 410.
} 
Isolation has resulted in the radical right being avoided as a coalition partner, however it has also significantly improved their changes of making it into parliament as they gradually consolidated their monopoly on the far-left yet still nationalist electorate. This monopoly is illustrated in Figure 3. As the political space after 1995 became slightly shifted towards economic right and libertarian politics (in large part due to EU induced public dissatisfaction with the incumbent social-democratic governments), the centre-right (CR) captured most of the libertarian economic left vote. This is in fact what is responsible for the 1996 and 1997 victories of the centre-right coalitions in Bulgaria and Romania. Furthermore, the social-democrats (SD) can be seen as moving towards the centre in the attempt to become catch-all parties, but this leaves the radical right (RR) essentially isolated in the socialist-authoritarian and nationalist pole of the political space.

This change in the socialist parties of the two states has also allowed the radical right to develop their multi-dimensional image of the enemy - one being the national minorities on one hand, the other being the other political parties. This feature was largely possible because of the break in the cooperation between the social-democrats and radical-right in the early 1990s after the elections of 1996 and 1997 in Romania and Bulgaria. As the radical right was being marginalized in the economically left region of the political spectrum ${ }^{80}$ within each state, it could now afford to point out towards the remaining political parties as not a group of political competitors spread over a left-right spectrum vying for power, but instead as a strongly-knit Mafia-group bent on pursing their own common interests rather than the interest of the electorate.

${ }^{80}$ The 1990s Bulgarian and Romanian radical-right being on the left of the political spectrum is a reoccurring statement throughout this thesis. Albeit the obvious confusing notion of the right being actually economically on the left, this feature (as explained in Chapter 3) existed nevertheless in Bulgaria and Romania due to the nationalist-communist legacies in both states. 
This feature is extremely important because the attack on what radical-right leaders in both countries called the "political Mafia" coincided with popular perceptions backed by EU condemnations of high levels of corruption among government officials. In the elections of 2000 and 2004 in Romania as well as in the elections of 2005 in Bulgaria, the radical right parties have focused extensively on the corruption of the other main-stream parties, issues that resonated among voters. As previously mentioned, the constant criticism received from the EU that also pointed to the intrinsic corruption in these countries, only added legitimacy to the radical-right message. In this sense, the genuine warnings and criticism coming from EU officials almost worked against mainstream parties and in favor of the radical right. The Romanian and Bulgarian electorates in 2004 and 2005 were likewise torn between desiring change and the uncertainty about the possible and genuine change that the opposition could represent ${ }^{81}$.

The radical parties in both states capitalized on these popular perceptions; election data from both countries illustrates the general strengthening of the radical right in these states in the early 2000s. ATAKA won over $8 \%$ of popular votes in the 2005 Bulgarian general elections ${ }^{82}$, while Greater Romania Party did considerably better than its $3.5 \%$ average of the $1990 \mathrm{~s}$, achieving $19.5 \%$ in 2000 and $13 \%$ in $2004^{83}$. In fact, after the 2000 elections, Greater Romania Party became the official opposition as it achieved better results than the previous centre-right governing coalition of which only two parties managed to barely squeeze past the $5 \%$ threshold (the Democrats and the historical National Liberal Party).

\footnotetext{
${ }^{81}$ William Downs and Raluca Miller, "The 2004 presidential and parliamentary elections in Romania," Electoral Studies 25 (2006):410.

82 "Historical Archive of Parliamentary Election Results in Bulgaria," Inter-Parliamentary Union, 2009, available from http://www.ipu.org/parline-e/reports/2045_A.htm. Internet; accessed 3 April 2009.

83 "Historical Archive of Parliamentary Election Results in Romania," Inter-Parliamentary Union, 2009, available from http://www.ipu.org/parline-e/reports/2262_A.htm. Internet; accessed 3 April 2009.
} 
Ultimately, until 2000-2001, Romanian and Bulgarian politics took similar paths, in large part due to EU passive and active leverage. In other words, the first post-1989 years were dominated by ex-communists unhindered by EU passive leverage, while the latter part of the decade was characterized by the rise of centre-right parties due to EU active leverage. What follows in both states is gradual dissatisfaction with the centre-right as well, thus leading to a move towards the centre by the left and hence a strengthening of the radical right at the left pole of political space.

\subsection{Seeking alternatives: 2000 and 2001 Elections}

As mentioned before, until 2000-2001 Romanian and Bulgarian politics took generally similar paths and the same trend can be observed after 2004-2005. Despite these similarities, however, the elections of 2000 in Romania and 2001 in Bulgaria have produced unique yet rather diametrically opposed results, accounting for the different performance of the radical right in the two countries. For this reason a brief analysis of these events is needed. The relatively high success of PRM in 2000 in particular deserves some further analysis, especially in light of the fact that in the 2001 Bulgarian elections, events took a completely opposite course. While the Romanian PRM came second only to the social-democrats, no radical right party entered the Bulgarian National Assembly in 2001. Another difference between the two is that the unsuccessful leadership under the reformist UDF coalition was not replaced by socialists as in Romania but rather by another group of reformers led by former Tsar Simeon II Saxe-CobourgGotha. 
The reason for this completely opposite political evolution is not due to the lack of Bulgarian popular dissatisfaction vis-à-vis the incumbent centre-right parties. Just like their northern neighbor, the political bankruptcy of the centre-right in Bulgaria was remarkably similar to that of the Romanian reformists, yet here socialists could not capitalize on the decreasing popularity of the UDF, the Bulgarian centre-right party. The explanation lies instead in the nature of popular perceptions of monarchy and the personality of the king in Bulgaria versus the largely republican attitude and lack of charisma of the king in Romania. This deprived the latter of a centre-right political substitute and instead forced a spatial rearrangement of already existent political parties. On the other hand, the political space in Bulgaria was shared in this case by the incumbent centre-right coalition, the socialists and the new popular Movement for Simeon II.

The existence of two instead of one centre-right coalitions has allowed for the UDF to take enough of the economically central political space as to prevent the socialists from moving too far towards the centre. This has resulted in the socialists still covering the economically-left space, hence preventing the consolidation of a successful communist-nostalgic radical-right party in 2001. Therefore, political competition in 2001 was reserved for the two centre-right coalitions (of which one, the Simeon II Movement, was highly popular) and the social democrats. This is because, interestingly enough, in this country, the WWII era Tsar Simeon II, returned and formed his own party, the National Movement Simeon II, something unique to Bulgaria and absent in all over Central and Eastern European states. At the 2001 legislative elections, his party won a sweeping $42 \%$ of the votes, making him the only monarch that, once deposed, has returned to power in his former country not by divine right but through the ballot box. The ability of Simeon II to do so lies primarily in his personality as well as populist message. Being 
educated in the west and a history as a successful businessman in Spain, where he was exiled for most of his life, added to his image as a reliable reformer. Ultimately, it is still the charisma of the leader that was responsible for the Movement of Simeon II's success. The only difference is that in this case, instead of a leader of the radical-right, Bulgaria was faced with a rather unconventional supply of a pro-western, pro-market and pro-reform former king that managed to single-handedly reshape demand in this country.

This stands in clear contrast to developments in Romania around the same time. The years between 1996 and 2000 were marked by the first true centre-right government in Romania after the 1989 Revolution. Albeit supported and cheered by the EU, the painful reforms it embarked on had similar results to those in Bulgaria. The last years of the decade were marked by decreasing living standards, civil strife which culminated in the 1999 Mineriad $^{84}$ as well as an agonizing three year recession ${ }^{85}$. The refusal of the incumbent centre-right president to run for a second term likewise diminished the chances for the reform-oriented coalition to stay in power as he was an important image and representative of the governing coalition. Consequently, demand for the centre-right decreased in favor of the social-democrats as a result of the perceived lack of success on the part of the governing coalition.

Moreover, the social-democrats became an unchallenged force that was now able to gather votes not only from the left but also from the disenchanted right. This was possible due to the slight change in the social-democratic message to continue reforms and improve living standards, thus successfully integrating the country in NATO and the EU. In essence, as a result

${ }^{84}$ The Mineriads were a reoccurring phenomenon in Romanian politics during the $1990 \mathrm{~s}$. They were often violent miner marches on Bucharest, aimed at achieving political changes. The last Mineriad of 1999 was a response to government reform which culminated in clashes between the gendarmerie and miners, ultimately ending in hundreds of arrests including that of miner leaders. It was an event that reflected the high costs of reform as well s the increasing unpopularity of the centre-right government.

85 "Romania," CIA World Factbook, 2009, available from https://www.cia.gov/library/publications/theworld-factbook/geos/ro.html. Internet; accessed 3 April 2009. 
of the centre-right coalition's failure to maintain its popularity, the Romanian political space in 2000 reverted to the one in 1992 (see fig. 2), save for the fact that the social-democrats were much closer to the centre eight years later than at the beginning of the decade.

The strengthening of the social-democrats together with their move towards the centre on economic issues and their promises to never again ally themselves with the Greater Romania Party enabled the latter to position itself as the sole representative of the far-left communist nostalgic electorate. The transformations occurring within the social-democratic party, making it therefore a catch-all-party, likewise gave the PRM an opportunity to concentrate on demonizing the other parties (including the socialists) and present them as a single homogeneous group interested only in accumulating resources at the expense of the population. The result of this strategy proved itself quite successful. PRM won almost $20 \%$ of the popular vote in the parliamentary elections while its leader, Corneliu Vadim Tudor, managed to make it to the second round of presidential elections against former socialist president Ion Iliescu.

The success of PRM is therefore firstly the result of a shift in demand due to dissatisfaction with the centre-right coalition. Secondly, it is also due to the social-democrats capitalizing on the popular dissatisfaction with the centre-right which allowed them to easily take advantage of the situation by moving towards the centre, guaranteeing to fulfill what the previous government could not.

Moreover, a return of the king at the head of his own political party such as in Bulgaria was highly unfeasible in Romania. Firstly, King Michael I of Romania lacks the charisma, energy, experience and political skill of Simeon II. Furthermore, when offered to run as president on behalf of the small Monarchist Party, King Michael I refused on the grounds that a king cannot be a president at the same time. This has resulted in the Monarchists asking his step- 
brother to run, a decision that was not only met by the disapproval and indignation of Michael I himself but also by that of his monarchists supporters among the electorate who saw Michael I as the only legitimate candidate to the throne. Lastly and perhaps most importantly, despite the few sympathizers, Michael I did not enjoy the great deal of popularity that Simeon II did, not just due to his own lack of personality but also because of the weakness that the monarchy has generally enjoyed among the Romanian public vis-à-vis the strong esteem that the king has had in the eyes of the Bulgarian population. Indeed, even before the communist take-over in 1947, republicanism and experiments with it, due to French influences, has been a constant plague for the Romanian monarchy and Michael's predecessors ${ }^{86}$.

Simply put, Bulgaria in 2001 is a unique case in Eastern Europe in regards to the election of a former king as prime minister as only here was there a strong demand for a king as well as the adequate supply of one. The timing for Simeon II's election is also important as the electorate was disillusioned with the left as well as the right and was receptive towards trying more unorthodox choices such as installing a former king as premier. Romania, by contrast was deprived of the availability of such a king and consequently the electorate focused on the choices already available. In essence, nevertheless, both strong performances by PRM as well as Simenon II in the elections of 2000 and 2001 respectively were the results of voter dissatisfaction with the available options as well as the supply of charismatic leaders.

\subsection{Elections and EU membership Negotiations}

When analyzing the 2004 and 2005 elections in Romania and Bulgaria, one can notice a more-or-less "return to normal" (see fig. 4). This is because the obvious change in both states is a

\footnotetext{
${ }^{86}$ Keith Hitchins, Romania (Bucharest: Humanitas Press, 2004), 42.
} 
decrease in the vote for the parties which managed to receive unusual number of votes in the previous elections; both Greater Romania Party and the National Movement Simeon II decreased to almost half the votes of 2000 and 2001. Likewise in both countries, the centre-right and socialists shared fairly equal shares of the vote suggesting the continuing consolidation of both as catch-all parties. By this point in time, when negotiations with the EU were well underway and a EU membership date of 2007 was clearly set, the socialists in both countries were completely

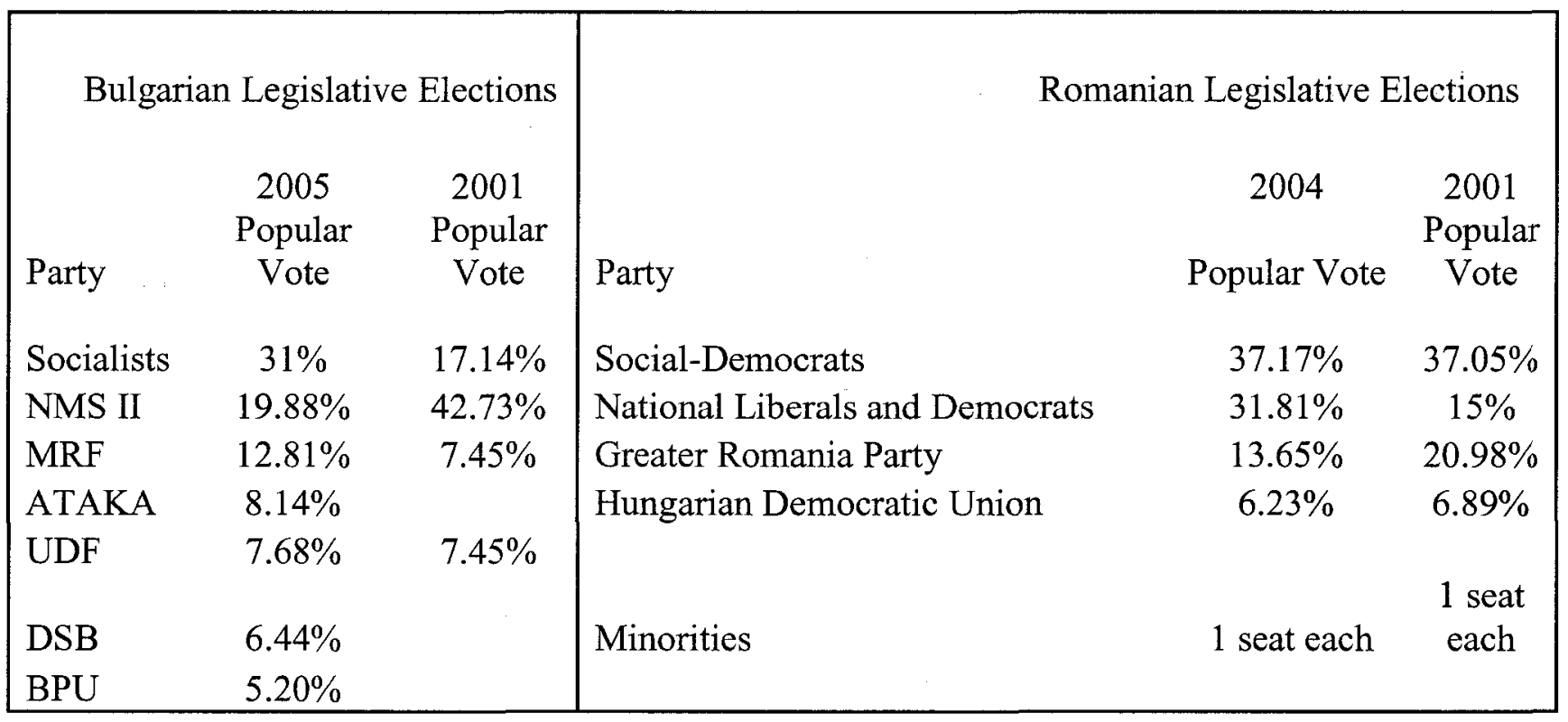

Fig. 4. Bulgarian and Romanian Legislative Election Results of 2005 and 2004 (source CIA World Factbook 2009).

committed to continuing reforms and concluding the pre-accession negotiation process. Furthermore, in Romania where the social-democrats were in power between 2000 and 2004, they could even boast of doing most of the work for that country's entrance into the Union. It was under the socialists that Romania joined NATO (perceived as a stepping stone towards joining the EU) and it was under their administration that government spending had been 
tightened, minimum wages were increased and economic growth boosted to $8.1 \%{ }^{87}$. It was likewise under Bulgarian socialists four years later, that negotiations with the EU were finalized and a flat tax of $10 \%$ was introduced, something rather bizarre for a left-leaning party to pursue and something that certainly would have been unthinkable in the early or mid-1990s.

Basically, if the socialists had been starting to move towards the centre by $2000-2001$, by 2004-2005, they were clearly an already established centre party rather than a leftist party. The benefits of EU integration were too appealing and the costs too high, for either Romanian or Bulgarian ex-communists to afford to miss the opportunity of renovating themselves as champions of democracy and reform.

Indeed, both the Bulgarian 2005 elections as well as the Romanian 2004 elections were not so much about conflicting party ideologies or policies since, as explained above, all mainstream parties shared the same goals and promises. Rather they were over the personalities of the leaders and the question of which one would be best suited to lead the country into the $\mathrm{EU}^{88}$, further indicating that both the mainstream left and mainstream right were now established catch-all parties.

This has further isolated the radical right parties on the left of the political spectrum, allowing them to attack all other parties for being corrupt and capitalize therefore on EU criticism (as well as the popular dissatisfaction) vis-à-vis the general corruption in these countries $^{89}$. In the Romanian elections particularly, Vadim Tudor even abandoned his usual

\footnotetext{
${ }^{87}$ William Downs and Raluca Miller, "The 2004 presidential and parliamentary elections in Romania," Electoral Studies 25 (2006):410.

${ }^{88}$ William Downs and Raluca Miller, "The 2004 presidential and parliamentary elections in Romania," Electoral Studies 25 (2006):410-411.

${ }_{89}$ In this respect, it is important to note that neither ATAKA nor PRM condemn EU integration outright but rather use the EU and EU criticism of corruption, redirecting this criticism towards the mainstream parties.
} 
xenophobia and anti-Semitism for the duration of the campaign ${ }^{90}$ and chose to focus solely on attacking the mainstream parties ${ }^{91}$. Despite still keeping its xenophobic message, ATAKA behaved in a somewhat similar fashion, focusing largely on the corruption of all Bulgarian parties and administrations since $1989^{92}$. Finally, in light of ever-increasing prospects of EU accession in 2007, both parties have indicated their disapproval with the manner in which the mainstream-parties conducted the negotiations with the EU for the purpose of claiming the success of a speedy integration in the detriment of the public interest.

Essentially, the same developments of the radical-right can be observed in both countries, however the earlier ability of PRM (unlike its Bulgarian counterpart) to capitalize on the move to the centre by the socialists can be attributed to the early rise of Vadim Tudor. It is therefore the supply-side rather than the demand-side factors which are responsible for this. By contrast, while PRM was fortunate enough to have a charismatic leader as early as 1991, ATAKA had to wait until 2005.

Furthermore, PRM benefited from the absence of a nationalist mainstream-left oriented party which could cover its political space, while the radical right in Bulgaria was for a long period of time hindered by the nationalist position of the mainstream socialists. Finally, the radical right in Bulgaria was likewise obstructed temporarily by an attractive albeit unconventional centre-right option in light of the unpopular incumbent centre-right party in 2001. This further hindered the successful consolidation of an ATAKA-like party for another four years.

\footnotetext{
${ }^{90}$ Vadim Tudor, until 2004 renown as an anti-Semite, declared himself a "philo-Semite" and promised to refrain from his xenophobic outbursts, a promise that was not only not kept but never taken seriously by the electorate or the other parties.

91 William Downs and Raluca Miller, "The 2004 presidential and parliamentary elections in Romania," Electoral Studies 25 (2006):412.

92 Boyka Stefanova, "Testing Theories of Radical Right Voting: Social Structure versus Political Agency and Electoral Support for the Attack Party in Bulgaria” Working Paper (2007): 20.
} 


\subsection{Conclusion}

In conclusion, between 1990 and 2004-2005, one notices a positive relationship between increasing EU "active leverage" as described by Vachudova and the consolidation of the communist-nostalgic radical right in Romania and Bulgaria. The reason for this is because although EU active leverage was successful in delegitimizing the ex-communists in the mid1990s and bringing pro-reform opposition parties to power, it also gave the former the incentive to reinvent themselves as catch-all parties, therefore moving away from the left and away from nationalism or cooperating with the radical right.

This has resulted in the isolation of the radical right in the far-left pole of the political spectrum which subsequently had two results. One was that the radical right could never again hope to be brought into a left-government coalition. Secondly, while being in government was no longer possible, achieving stronger results and making it into parliament as a consequence of the converging on the centre of the mainstream parties did become more likely. While some differences in the timing of the process do exist between Romania and Bulgaria due to the presence of a centre-right alternative in the form of the Movement for Simeon II in the latter in the 2001 Bulgarian elections, the same phenomenon can be largely observed in both states.

The events that transpired during this period illustrate the strong relationship between outside institutional forces (in this case the EU), the demand-side as well as the supply- side for mainstream parties as well as the changes in the demand and supply of the radical right as a result of these interactions. While not intended, EU conditionality between 1995 and 2005 has been to a large extent responsible for the strengthening of the radical right in these states. As 
explained in previous chapters, this stands in stark contrast to the other Central and Eastern European countries where strong communist-nationalist legacies did not exist, thus making the appearance of radical right parties of the communist past impossible. EU conditionality, therefore, had no way of strengthening a party-family that did not even exist in the other states of Central and Eastern Europe. 


\section{Chapter 5}

\section{Reactions to Euro-Atlantic Integration: Changes in the Political Space}

\subsection{Introduction}

We are staunchly promarket. Businesses must thrive here. And the Romanians that left abroad should be the ones to come back and take up the jobs available now, not the immigrants. Although immigration is not an issue now, it will be in the future and we are definitely against it. Immigrants must not come here the way they did in the West.

Trache Nicolae Petre, Secretary General New Generation Party (2008)

The previous chapter has outlined the demand-supply dichotomy under the regulation of external institutional factors. Specifically these external factors have been demonstrated to be the prospect of EU integration and active leverage or EU conditionality just before 2004-2005, a period when EU accession became no longer a distant goal but an actual realistic prospect. By 2005, both Romania and Bulgaria had their accession guaranteed for 2007 or at the latest, 2008. While EU conditionality can be said to have definitely influenced the political space in these states until the mid-2000s, after this period when accession became obvious, the power of conditionality dwindled. 
Nevertheless, the political space has still been influenced indirectly by the EU. This is because with the prospect of EU integration, Romania and Bulgaria started witnessing increasing foreign direct investment which together with the privatization of the late 1990s and early 2000s resulted in the exposure of workers not just to capitalism but also to the global market much like their counterparts in the West. The consequence of this was the electorate's shift away from the socialist (communist-nostalgic) and authoritarian versus capitalist-libertarian axis and onto the opposite capitalist-authoritarian and socialist-libertarian axis, just as in the West.

Migration likewise increased during this period as visas were dropped for Romanians and Bulgarians in the Schengen space as early as 2002. This has resulted in large numbers of skilled or unskilled laborers from both countries immigrating to other western states and experiencing the influences of globalization and the global-market perhaps even more intensely that those that stayed behind. Both this exposure at home as well as the one abroad due to migration has resulted in the re-socialization of voters (due to the changing nature of the workplace) and consequently the changing preferences of some voters which have created new demands for radical right parties unseen until now in either Romania or Bulgaria. Ultimately, this is mirroring the same feature in the West thirty years prior as described by Kitschelt ${ }^{93}$. The arrivals of the New Generation Party (NGP) in Romania as well as Democrats for a Strong Bulgaria (DSB) in Bulgaria illustrate the renegotiation of the supply in light of changing voter preferences in the period roughly following $2004-2005^{94}$.

This chapter will explore this arrival of the new right in light of changing voter in Romania and Bulgaria. Subsequently, it will proceed with an analysis of the performance of the

93 Herbert Kitschelt, The Radical Right in Western Europe: A Comparative Analysis (Ann Arbor: University of Michigan Press, 1995), 7-8

${ }_{94}$ The word 'roughly' is meant to indicate that the years 2004-2005 are an approximation of the time when this new trend can be seen. As it will be shown in this chapter, DSP has in fact entered the Bulgarian parliament as early as 2005 . 
new radical right in the period after 2005, specifically its performance in the European Union Parliamentary elections of 2007 as well as the Romanian legislative elections of $2008^{95}$. The analysis will be focused not just on the changes in demand and supply during these elections but also on institutional factors and their impact on the performance of these parties.

While the disappearance of the former communist-nostalgic radical right, which has dominated Bulgarian and Romanian politics until recently, has not yet occurred, this chapter will demonstrate that due to the rise of the new radical right in these states, the former has suffered considerable setbacks. Election data will be used to illustrate that as the radical vote is now split between the two, this may even hinter the possibility of either the old-radical right or the new radical right to actually enter future parliaments.

\subsection{The New Radical Right in Bulgaria and Romania}

Before proceeding to the effects of EU integration, a brief overview of what the new radical right means is necessary as well as a glimpse into the Romanian and Bulgarian parties included in this category. While the Romanian and Bulgarian radical-right parties studied up until this point have been parties of the communist-past, the following are rather new radicalright (NRR) parties, emergent in the 2004-2005 period, which share very little if anything with the former. On the other hand, they are much more similar to the NRR in Western Europe such as the National Front in France, the Vlaams Belang (Flemish Bloc) in Belgium or the Freedom Party in Austria.

${ }^{95}$ Bulgarian legislative elections will only take place in June of 2009 however poll data does offer some indication regarding the evolution of the radical right in this country as well. 
A few underlying factors can be observed in both the Romanian NRR, the New Generation Party (NGP) under its charismatic leader and football club owner George Becali, as well as the Bulgarian new radical right, Democrats for a Strong Bulgaria (DSB). Firstly, unlike the radical-right parties of the communist-past, they are staunchly pro-market, capitalist and advocate a decrease in taxes, the introduction of investor-friendly tax systems, a small state and less bureaucracy. Both $\mathrm{NGP}^{96}$ and $\mathrm{DSB}^{97}$ state that the social-democrats are the primary impediments to development and regard them as directly linked with the former communist party. The New Generation Party goes even further, specifically identifying Greater Romania Party (PRM) as an extremist party but with communist connections, a feature that would make it incompatible with the doctrine of the $\mathrm{NGP}^{98}$. Consequently, both parties, given the economic doctrine they advocate, place themselves on the right on economic issues just as the NRR in the West.

On the authoritarian-libertarian axis, the DSB and NGP again choose to affiliate themselves with their western counterparts. DSB explicitly call for imposing a government which would guard the population from communists and the 'Mafia-cartels' that have ensued as a result of former-communists/socialists administrations ${ }^{99}$. NGP is even more adamant about its rejection of liberal ideas as its doctrine clearly states that, besides rejecting social-democracy, "NGP rejects the dogmas of liberalism (which lead the individual to be guided by exclusive

\footnotetext{
96 “New Generation Party Doctrine," New Generation Party, 2008, available from http:/www.png.ro/dmdocuments/statut_PNG_RO.doc. Internet; accessed 31 November 2008.

97 "Democrats for a Strong Bulgaria Structure," Democrats for a Strong Bulgaria, 2009, available from http://www.dsb.bg/display.php?show_category=1. Internet; accessed 3 April 2009.

98 "New Generation Party Doctrine," New Generation Party, 2008, available from http://www.png.ro/dmdocuments/statut_PNG_RO.doc. Internet; accessed 31 November 2008.

99 "Democrats for a Strong Bulgaria Structure," Democrats for a Strong Bulgaria, 2009, available from http://www.dsb.bg/display.php?show_category=1. Internet; accessed 3 April 2009.
} 
personal and egoistic interest in everything she/he does) ${ }^{p 100}$. The authoritarian nature of the party is likewise reflected in its rejection of immigrants, despite that, as the party itself admits, the number of immigrants in Romania is rather negligible ${ }^{101}$. Nevertheless, in view of what seemed to be a booming economy in 2008 , the party has preemptively positioned itself for the return of Romanians abroad and against a possible massive inflow of immigrants as the country was facing the prospect of an increase in jobs to match the economic growth.

By choosing to adopt an authoritarian view of politics and the state, both parties are effectively stating that their position on the political spectrum resembles that of their Western European counterparts. In other words, by being pro-market yet rejecting liberalism and socialism, they position themselves at the far-right pole on an authoritarian-capitalist versus libertarian-socialist axis - identical to that described by Kitschelt in the West.

Unlike in the case of Kitschelt's work however, where he adopts a demand-side approach, in this case the explanation so far is supply-side oriented only, as until this point it has only been established that it is the parties themselves that claim this position and therefore imply the existence of such a western-like axis in the political space. For the purpose of completing this picture, this chapter will attempt to explore whether indeed this is because a NRR party demandshift in this direction has occurred as well, due to a re-socialization of voters.

Before doing so, however, it is important to point out that the NGP as well as DSB are not exactly perfect copies of their western counterparts. Both have features distinct to the partypolitics of their respective states. The New Generation Party is perhaps the more peculiar of the two and indeed if analyzed from a pan-European perspective on the new radical right, it is the most peculiar European new radical right (NRR) party as well. While NGP rejects

\footnotetext{
100 "New Generation Party Doctrine," New Generation Party, 2008, available from http://www.png.ro/dmdocuments/statut_PNG_RO.doc. Internet; accessed 31 November 2008.

${ }^{101}$ Trache Nicolae Petre, NGP Secretary General - interview conducted in 2008.
} 
$x^{x}$ onophobia ${ }^{102}$, anti-Semitism and ultra-nationalism, the party doctrine includes a highly religious element that goes beyond the Christian-democracy that NGP claims to adhere to ${ }^{103}$. The reason for this is twofold.

Firstly, as the NGP itself recognizes in its party doctrine, Romanians are generically one of the most religious peoples in the EU, second only to the Poles and the Maltese ${ }^{104}$. In fact the NGP cites census as well poll data, affirming that between $80 \%$ - $90 \%$ of Romanians are religious compared to higher percentages only in the aforementioned EU states and Turkey ${ }^{105}$. The New Generation Party is not merely a Christian party, however, but rather an exclusively Orthodox-Christian party. In this sense, the party takes almost an ethno-centric position as it advocates just the religion associated with the majority. Albeit making some reference to Christian unity, NGP stresses extensively the Orthodoxy of the Romanian people, the importance of Orthodoxy in all aspects of life (implying even political life) and the link between Orthodoxy and the political right as supposed to atheism and the political left ${ }^{106}$.

Having said this, NGP's focus on religion is not just a means to market itself in light of what it perceives to be an unspoiled religious constituency. The second reason for its rather unique religiousness is the party leader himself. George Becali, a renowned former-peasant yet successful Bucharest businessman, real-estate baron and football club owner ${ }^{107}$, has never made

\footnotetext{
102 The NGP doctrine in fact points out to the radicalism and xenophobia of the PRM and repeatedly disassociates itself from it in the official party doctrine.

${ }^{103}$ While not overtly xenophobic, the ultra-Christian message of the NGP has made it rather homophobic and an overtly homophobic discourse has been present in Becali's speeches.

${ }^{104}$ Loek Halman and Thorleif Pettersson, "Religion and Social Capital in Contemporary Europe: Results from the 1999/2000 European Values Stduy", in Research in the Social Scientific Study of Religion. David O. Mobeg and Ralph L. Piedmont, (Leiden: Brill, 2001), 78.

105 "New Generation Party Doctrine," New Generation Party, 2008, available from http://www.png.ro/dmdocuments/statut_PNG_RO.doc. Internet; accessed 31 November 2008.

106 "New Generation Party Doctrine," New Generation Party, 2008, available from http://www.png.ro/dmdocuments/statut_PNG_RO.doc. Internet; accessed 31 November 2008.

107 "George Becali," New Generation Party, 2008, available from http://www.png.ro/conducere/89 Internet; accessed 31 November 2008.
} 
his devout faith a secret in TV appearances or during election campaigns and has transplanted his personal philosophy on life to the New Generation Party as well.

Consequently, due to the nature of the leader himself as well as an obvious attempt to appeal to what the party perceives to be an intrinsic feature of the general population, the NGP stands alone as an ultra-religious party among the NRR party family. While it might seem rather trivial, this very feature of the NGP implies the need of a somewhat deeper discussion of the party's own conceptualization of the political space. Therefore, while the rest of the NRR can be said to adhere to Kitschelt's two-dimensional axis, in the case of the NGP one can speak of a three-dimensional conceptualization of the political space. In other words, besides the capitalistsocialist and authoritarian-libertarian axes, there is a third religious versus atheist axis, at least as claimed by the New Generation Party itself.

In the perception of the NGP (but by no means verified by scholarly works or studies), there is the implication that this third religious-atheist axis is strongly related to the capitalist versus socialist axis. This is because socialism is associated by the NGP with the former atheist Communist Party, leaving capitalism for the 'non-atheists' (represented by the ultra-Orthodox NGP). A 3D mapping of this party-centric perception of the Romanian political space is nevertheless rather redundant for the purpose of this study. This is because firstly, as previously mentioned, this is a party-centric view of what the political space is and there seems to be little evidence that it is a representation of the actual political space taking into consideration both the demand as well as the supply of radical right parties. Secondly, this feature is observed only in the case of Romania and is not generalizeable as Bulgaria or any other Western or Eastern European state does not share the ultra-religious element. The ultra-religious aspect of the New 
Generation Party remains however a special feature worth mentioning and perhaps even worthy of further study.

While religion is unique to the Romanian NRR, DSB in Bulgaria offers an example of a different sort of distinctiveness. While not overtly xenophobic, DSB displays characteristics similar to those of the ATAKA party (which is a party of the communist-past) when it comes to national minorities. Specifically, while not anti-Semitic or anti-Roma, DSB does possess a nationalistic tone in relationship to Bulgaria's greatest minority, the Turks. In particular, the party is highly critical of the way that the Movement for the Rights and Freedoms (the largely Bulgarian ethnic party) has succeeded to monopolize the Turkish ethnic vote, hence implying its unconstitutional nature ${ }^{108}$. DSB has often criticized the leader of Movement for Rights and Freedoms (MRF) and overtly stated its complete disagreement to the "Bulgarian ethnic model" defined by the $\mathrm{MRF}^{109}$. In this respect, DSB comes closer to the typical radical right stance of the communist stance than its Romanian counterpart.

Consequently, one cannot speak of a third dimension of the political space as in the case of the NGP in Romania but rather of an overlap between the spatial arrangement of the early 1990s on a nationalist/authoritarian and socialist axis versus a libertarian-capitalist one and the completely opposite axis on which DSB itself claims to be positioned on. DSBs attitude towards the Turkish minority reveals also something about nationalism in general in this country as the topic seems to be a feature hard to escape from for any party in Bulgaria given the highly contested legality of the MRF in Bulgarian politics.

\footnotetext{
108 The Bulgarian constitution forbids the formation of parties based on ethnic lines and MRF due to its largely Turkish membership as well as support has been often accused of being unconstitutional, particularly by radical right parties of the communist-past such as ATAKA as well as NRR like DSB.

109 "Democrats for a Strong Bulgaria Structure," Democrats for a Strong Bulgaria, 2009, available from http://www.dsb.bg/display.php?show_category=1. Internet; accessed 3 April 2009.
} 
This is obvious as, while not to the same degree as DSB, a second right party, Citizens for European Development of Bulgaria (GERB), has also made reference to the monopoly of the MRF on the ethnic vote and the need to break that monopoly by appealing to Turkish-Bulgarians as well as ${ }^{110}$. GERB, however, cannot be considered to be equivalent to NGP or a second DSB in Bulgarian politics. GERB in fact is not an NRR party at all but rather a populist pro-capitalist party. The only reason for its mentioning here is in order to clearly draw a line between what an Eastern European NRR is and what it is not. The NRR is pro-market and capitalist and GERB falls within that category. The NRR is likewise dependent on a strong charismatic leader and again GERB does posses one if not in fact two such leaders ${ }^{111}$. However the NRR is likewise authoritarian. GERB by contrast is definitely not. While advocating lower taxes and a smaller state with less bureaucracy, GERB is nevertheless a European People's Party with liberal conservative ideals ${ }^{112}$. While stressing such things as the importance of the family as the foundation of society or the need to fight the corruption of the current socialist government, GERB does not fall in the category of authoritarian parties and nor do its leaders reveal any hint of authoritarian-leaning politics in their political discourse.

Ultimately, unlike GERB, DSB and NGP do reveal (aside from their individual peculiarities) a combination of pro-capitalist policies with an inclination towards an authoritarian discourse. Both features are in stark contrast to ATAKA and PRM which are parties of the communist past. The new NGP and DSB resemble, therefore, the new radical right in Western Europe. Nevertheless, in order to fully confirm this conclusion about the Romanian and

\footnotetext{
${ }^{110}$ Tsvetan Tsvetanov, GERB Party Leader - interview conducted in 2008.

${ }^{111}$ While the official party leader is the highly popular Tsvetan Tsvetanov, the actual recognized leader of GERB is Boyko Borisov, mayor of Sofia.

${ }^{112}$ Tsvetan Tsvetanov, GERB Party Leader - interview conducted in 2008.
} 
Bulgarian political space after 2005, it is important to investigate the possible societal reasons, if any, for such a dramatic shift.

\subsection{Effects of EU Integration}

EU integration has brought about a series of changes, the most notable being the free inflow of capital (FDI) and the prospect of a free outflow of labor towards economically more appealing regions of the Union. These two aspects have had a crucial impact on those exposed as it re-socialized them, consequently changing their electoral preferences. In many respects, this was done in a similar fashion in which trans-national corporations and exposure to globalization have re-socialized blue collar workers in the West ${ }^{113}$.

The free inflow in the form of foreign direct investment was privatization-driven as both Romania and Bulgaria have pursued slow but straightforward privatization policies which attracted $\mathrm{FDI}^{114}$. FDI was therefore strongly related to the start of privatization-related selling of state owned companies to foreign ones ${ }^{115}$. The distribution of foreign direct investment was concentrated in the financial services, telecommunications, trade, the banking-sector as well as manufacturing. Leather-industries, chemicals and steel production in Romania and mining as well as food processing in Bulgaria were one of the highly foreign-penetrated industries in the two states $^{116}$. As a result of this, blue-collar workers were the most affected by the change from exposure to state-owned companies towards the exposure to transnational global corporations.

\footnotetext{
${ }^{113}$ Herbert Kitschelt, The Radical Right in Western Europe: A Comparative Analysis (Ann Arbor: University of Michigan Press, 1995), 7-8.

${ }^{114}$ Gabor Hunya, "FDI in South-East Europe in the early 2000s" A study commissioned by the Austrian Ministry of Economy and Labour (2002): 3.

${ }_{115}^{15}$ Ibid, 6.

${ }^{116}$ Gabor Hunya, "Foreign Direct Investment in South-East Europe in the early 2003-2004" A study commissioned by the Investment Compact for South East Europe OECD (2004): 3.
} 
The implication of this is that the change from state-owned to corporate-owned enterprise altered the association between the authoritarian workplace environment and socialism (which existed prior to privatization) with an association between the authoritarian workplace environment and capitalism by those exposed to the milieu of those enterprises. The end result of this was a similar recreation of the political space on a two-dimensional axis much as in the West.

Ultimately, an obvious implication of increasing foreign direct investment and privatization is that blue-collar workers were exposed in Romania and Bulgaria to the same factors that their Western European counterparts faced during the 1980s and 1990s. This means that the same re-socialization at the workplace, which occurred in the West, has been repeated in the East and ultimately the changes in voter preferences noticed by Kitschelt in the former must have occurred in the latter as well.

Another effect of EU integration that re-socialized voters and affected changes in voter preferences is migration. Following 2002, both Romanian as well as Bulgarian citizens were allowed to travel to Schengen countries without visas. Working permits were also increasingly easier to procure and as a result, the number of Romanian and Bulgarian migrant-workers in Western European states surged. Destination countries for Romanians and Bulgarians were Germany, the UK, but most importantly Italy and Spain. In fact, almost $7 \%$ of the total Romanian population of 22 million and over $4 \%$ of the total Bulgarian population of eight million had become migrant workers in Italy $^{117}$ and $\operatorname{Spain}^{118}$ alone in the years between 2004 and 2008.

117 "Foreigner Citizens. Demographic Balance for the year 2007 and Resident Population on 31th December - All countries of citizenship Italy," Italian National Institute of Statistics.,2008, available from http://www.demo.istat.it/str2007/index_e.html. Internet; accessed 22 October 2008.

118 “Municipal Provisional Data as of January 1 2008," Spanish National Institute of Statistics, 2008, available from http://www.ine.es/prensa/np503.pdf. Internet; accessed 28 October 2008. 
As a result of this mass-migration, the migrant-workers themselves underwent a shocking transition to completely different working environments where they occupied blue-collar positions, including those that the local populations were reluctant to assume. Positions often occupied by these migrants include those in agriculture and construction. This has affected the manner in which they viewed the working-place. Migrants saw themselves in a pyramidal relationship where they themselves as workers occupied the base and the Spanish or Italian patrone - the peak. On top of this, their large numbers raised the suspicion and often the hostility of the locals in the countries to which they migrated.

This hostility has often made itself visible particularly in Italy against the Romanian migrants, thus altering even more the socialization of the blue-collar migrants here which saw this xenophobia as representative of the West. Subsequently, this translated into the migrant workers taking on the anti-liberal and xenophobic message of the radical-right in Spain and Italy themselves. Once these migrant workers returned home, they ended up taking this anti-liberal xenophobic message to their countries of origin ${ }^{119}$. This finding is rather important as until now, most often the effect of migration is analyzed only from the point of view - and for the purpose of - studying the far-right in the country of immigration. This study, however, suggests that it is not just the population in the state of immigration that is exposed to the forces of globalization (and in essence another dimension of the international market, that is the immigrants in this case). In fact, the situation more likely is taking on the character of a clash where both groups, by being exposed to each other, attribute negative outcomes to processes of globalization as well as to the international market.

Research data, albeit lacking in Bulgaria, seems to confirm this at least in the Romanian case. Opinion polls show that although NGP managed to take some voters from PRM, PRM's

\footnotetext{
${ }^{119}$ Cristian Preda, Bucharest University Faculty of Political Sciences - interview conducted in 2008.
} 
electorate is older and communist-nostalgic ${ }^{120}$ while those likely to vote for NGP in legislative elections and for Becali in the presidential election are largely urban blue-collar workers and young males, lacking post-secondary education. Women and males over 35 as well as those with post-secondary education are underrepresented among NGPs electorate ${ }^{121}$. It is important to note that this characterization already matches almost perfectly the new radical right voter in the West as described by Kitschelt. However, in relation to the question of migration, opinion polls have established that NGP has indeed attracted a disproportionately higher number of citizens that have worked abroad ${ }^{122}$. This seems to support the argument that working in the West and the socialization following this experience abroad have reshaped voter preferences, radicalizing

\begin{tabular}{|c|c|c|c|c|c|}
\hline Party & $\begin{array}{l}\text { Bulgaria Elections } \\
2005 \text { Natioanal } \\
\text { Assembly } \\
\text { Popular Vote }\end{array}$ & $\begin{array}{l}2007 \text { EP } \\
\text { Popular } \\
\text { Vote }\end{array}$ & Party & $\begin{array}{c}\text { Romania } \\
\text { Elections } \\
2007 \text { EP } \\
\text { Popular } \\
\text { Vote }\end{array}$ & $\begin{array}{l}2008 \text { National } \\
\text { Elections } \\
\text { Popular Vote }\end{array}$ \\
\hline Socialists (BSP) & $31 \%$ & $21.41 \%$ & Social-Democrats (PSD) & $23.11 \%$ & $33.09 \%$ \\
\hline $\begin{array}{l}\text { National Movement Simeon II (NMS II) } \\
\text { Movement for Rights and Freedoms } \\
\text { (MRF) }\end{array}$ & $\begin{array}{l}19.88 \% \\
12.81 \%\end{array}$ & $\begin{array}{l}6.27 \% \\
20.26 \%\end{array}$ & $\begin{array}{l}\text { Democratic Party } \\
\text { Hungarian Democratic Union }\end{array}$ & $\begin{array}{l}36.59 \% \\
5.52 \%\end{array}$ & $\begin{array}{l}32.36 \% \\
6.17 \%\end{array}$ \\
\hline $\begin{array}{l}\text { Union of Democratic Forces (UDF) } \\
\text { ATAKA }\end{array}$ & $\begin{array}{l}7.68 \% \\
8.14 \%\end{array}$ & $\begin{array}{l}4.74 \% \\
14.20 \%\end{array}$ & $\begin{array}{l}\text { Liberals } \\
\text { Greater Romania Party } \\
\text { (PRM) }\end{array}$ & $4.15 \%$ & $18.57 \%$ \\
\hline Democrats for a Strong Bulgaria (DSB) & $6.44 \%$ & $4.35 \%$ & New Generation Party (NGP) & $4.85 \%$ & $2.27 \%$ \\
\hline GERB & * & 21.68 & Minorities & & 1 seat each by default \\
\hline
\end{tabular}

Fig. 5. Most recent National Legislative and European Parliament (EP) Elections in Bulgaria and Romania

those most exposed to the effects of the international market thus bringing them in an authoritarian-capitalist pole of the political space which the NRR could now tap into.

These findings are by no means meant to suggest that after 2004 or 2005 , the new radical right has completely taken over from the old radical right of the communist past as a result of

\footnotetext{
${ }^{120}$ Mircea Comsa, Opinion Poll Barometer (2006): 50.

121 Ibid, 60.

${ }^{122}$ Mircea Comsa, Opinion Poll Barometer (2006): 51.
} 
these abovementioned changes. The shift is not abrupt but rather much more gradual and in fact up until now, one cannot speak of a complete takeover from the old-radical-right but rather of a slow emergence of the NRR. As the recent European Parliament and national elections indicate, the NRR has managed to co-exist with the old communist-nostalgic radical right of the 1990s (see Fig 5).

The table above contains data from the latest national as well as EP elections, however in the case of Bulgaria data from the elections of 2009 is not yet available. Opinion polls, nevertheless, put ATAKA at much lower levels of roughly 5\% (making its entry into parliament questionable), while the other parties faring similarly to the 2007 European Parliament elections $^{123}$. As can be seen from the table, the NRR has made headway, at least in Bulgaria as early as 2005 , managing to barley cross the electoral threshold necessary to enter parliament. In Romania, the NRR has gained significant momentum, almost making the threshold in the 2007 European parliament elections.

Another noteworthy feature is that the vote for the old radical right has decreased substantially in the case of Romania from $13.65 \%$ in 2004 compared to under-5\% in 2007 and 2008. Similarly, in Bulgaria the vote for the old radical right dropped from 2007 until the present according to the recent polls. This is largely to be expected since, as explained previously, the resocialization of voters in the working environment has reshaped voter preferences moving them away from the previous axis on which the old communist-nostalgic radical right was situated. Over time this process is expected to continue even further, hence the old radical right is likely to continue its decrease. For now however, it is safe to state that the two co-exist on two axes rather than one (see Fig. 6).

\footnotetext{
123 "Vote Intentions," Alpha Research in Bulgaria, 2009, available from http://www.aresearch.org/electoral/1686.html. Internet; accessed 3 April 2009.
} 


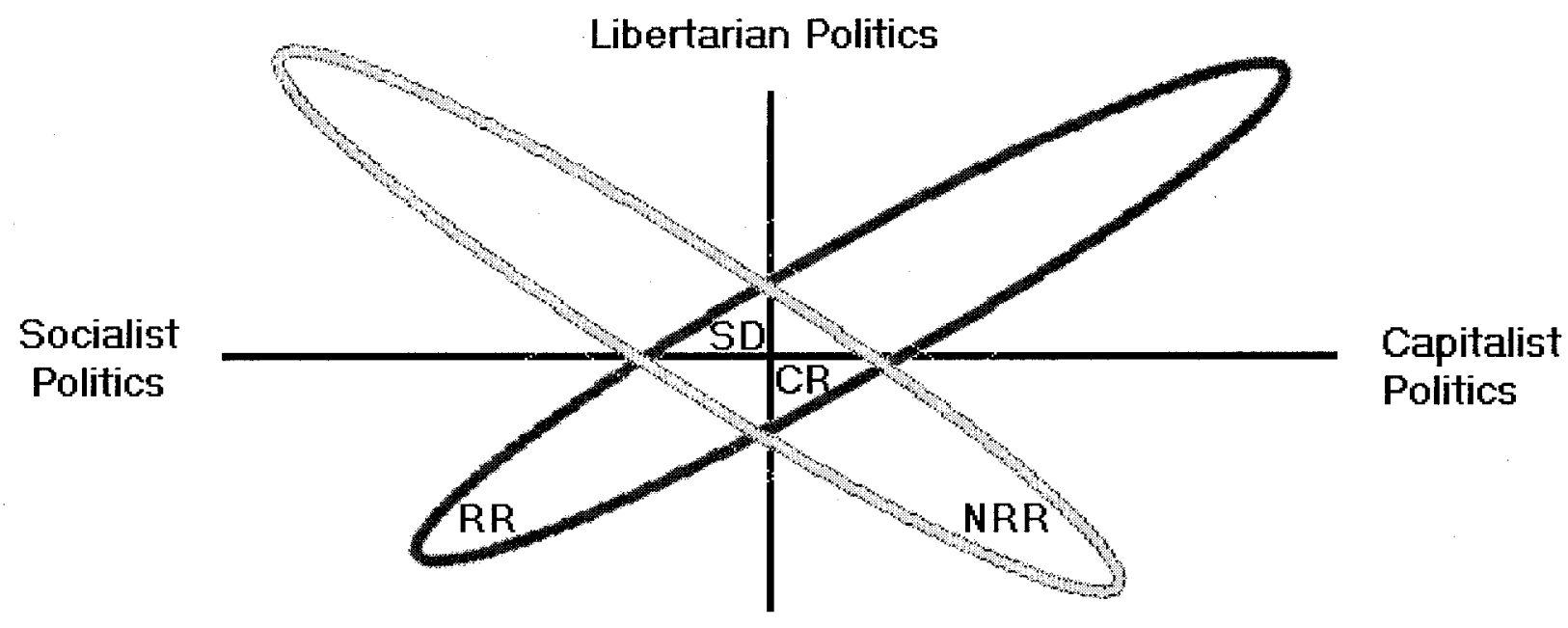

Authoritarian/Nationalist Politics

Graphic Representation Developed by the Author Drawing on Conceptualization Provided by Kitschelt.

Fig. 6 Political Spectrum in Romania and Bulgaria in the late 2000s (RR-radical right of communist past, SD - Social Democrats, CR - centre-right, NRR - New Radical Right)

Figure 6, depicts this coexistence through both the old socialist-authoritarian versus capitalist-libertarian axis (in dark) as well as the newly created capitalist-authoritarian versus socialist-libertarian axis (in grey). The latter resembles the same spatial mapping employed for the Western European political spectrum. As stated before, with the further weakening of the old radical right of the communist past, it is expected that the first (dark) axis will gradually become less and less important over time, eventually withering away altogether, while the second one (the grey) will come to represent the entire political space in these states.

Returning to Figure 5, the most obvious feature of the table which at first glance does not seem to confirm the theory of the NRR taking root in the East is the sudden drop of the NGP vote from 2007 to 2008 by more than $50 \%$. This is due to a number of reasons, all of which translate into institutional regulators preventing or hindering the NRR from entering parliament. 
The first reason deals with the political space provided by the other (mainstream) parties. In light of the economic crisis, the discourse of both the mainstream left as well as the mainstream right radicalized significantly just before the elections. The left took an increasingly more socialist tone while the centre-right Democratic-Liberal Party took an increasingly more authoritarian and populist tone, in part due to its leader, the Romanian president himself, Traian Basescu ${ }^{124}$. When applying this to Fig. 6 , the $\mathrm{SD}$ as well as the $\mathrm{CR}$ have moved essentially slightly more to the poles on the light-grey axis. Albeit this move was only provisional and by no means permanent, it created nevertheless an impediment for the NGP to consolidate its own position in the authoritarian-capitalist pole of Romanian politics as this space was becoming gradually invaded by the mainstream centre-right.

Another reason for NGPs failure to enter parliament in 2008 was the new electoral law in Romania in 2008 which prevented smaller parties from fulfilling the necessary requirements to enter parliament ${ }^{125}$. Consequently, a discussion of the changes in electoral law during the 20072009 period will follow below which will illustrate the importance of political marketplace regulators to the success of fringe parties like the radical right. This discussion will include the implications of institutional constraints such as electoral laws and electoral thresholds by taking into account the performance of the NRRs during the European Parliament Elections as well.

\subsection{Electoral Systems and the Radical Right}

Electoral systems, as the works of Duverger, Lijphart and Taagepera point out, can have a crucial impact on party systems and by consequence, the political system in general. Given that

\footnotetext{
${ }^{124}$ Dr Vlad Nistor, Romanian Diplomatic Institute - interview conducted in 2008.

125 This aspect can also be used to explain PRM's failure as well.
} 
in any European country, the radical right is represented by small parties, the less advantageous the electoral system will be for small parties, the less likely are the chances for right-wing parties to make it into parliament. Consequently, in such situations, the psychology of voters will change as they will prefer to vote for the second-best larger party which has a chance to win, rather than waste votes.

The major difference between electoral systems that can significantly affect the party system is that between proportional representation (PR) based on party lists and the majoritarian or first-past-the-post system, where the winner of a plurality takes the seat in that constituency. The majoritarian system has been criticized for allocating large parties a disproportionately large number of seats compared to votes obtained while marginalizing smaller parties. PR, on the other hand, favours small parties yet it usually leads to a large number of them making it to parliament and thus forces coalitions and less stable governments. Aside from Romania, which has switched to a semi-majoritarian system in 2008 , few countries in Europe use the majoritarian system ${ }^{126}$ and for the European Parliament all states are required to use some sort of $\mathrm{PR}^{127}$. Yet the ways to calculate proportional representation vary by country and the European Parliament Electoral Procedures make no specification as to a general pan-European calculating system.

Although there is high variation between the different systems, the largest remainder and the highest average systems are the main ones for elections based on party lists. In essence, for the first, votes are allocated, after which if extra seats remain, they are distributed according to the party that has the largest remainder from the total number of votes accumulated. This is in essence the Hare formula.

\footnotetext{
${ }^{126}$ Bulgaria uses proportional representation just like Romania did prior to 2008.

127 "European Parliament Electoral Procedures," European Parliament, 2007, available from http://www.europarl.europa.eu/facts/1_3_4_en.htm. Internet; accessed 3 April 2009.
} 
The highest averages systems, with the d'Hondt method being the most widely used variation, basically calculates the allocation of seats based on the party which, after an additional seat is allocated to it, can have the highest average of votes per seats ${ }^{128}$. There are several variations for both these general systems as well as a separate PR system, the single transferable vote, which ensures more proportionality and votes based on individuals rather than parties. However, for the purpose of this analysis, what is important to establish is that proportional representation favours smaller parties and first-past-the-post favours larger parties. When speaking strictly of proportional representation, the highest averages system clearly favours larger parties while the opposite is true for the largest remainder system. Subsequently, it should be obvious that countries which use the former system should have less successful far-right parties, other things begin equal, while countries using the latter will have a plurality of parties, including extremist ones. This difference however is not essential when studying the evolution of the radical right in either state, as both Romania and Bulgaria used D'Hondt continuously until $2008^{129}$.

The conclusion to be drawn from this is that major differences in electoral systems, such as majoritarian versus proportional representation, may perhaps result in drastic differences in election results. On the other hand, as Pippa Norris herself concludes, the difference between different ways of calculating votes in the PR system (especially in new democracies) may not lead to similar significant changes ${ }^{130}$. As both Bulgaria and Romania have always used the same

\footnotetext{
${ }^{128}$ Andrew McLaren Carstairs, A Short History of Electoral Systems in Western Europe. (UK: Lowe \& Brydone Limited, 1980), 17.

129 "European Election Database," Norwegian Social Sciences Data Service, 2006, available from http://extweb3.nsd.uib.no/civicactivecms/opencms/civicactive/en/Data. Internet; accessed 3 April 2009.

${ }_{130}$ Pippa Norris, Radical Right: Voters and parties in the Electoral Market (NY: Cambridge University Press, 2005), 124.
} 
D'Hondt formulae, for the purpose of this study only the effects of first-past-the-post (majoritarian) versus proportional representation will be analysed.

A final note on electoral law is that, as mentioned in other chapters, an important feature of a proportional representation system is the threshold determining inclusion or exclusion from parliament. An obvious fact is that high thresholds would usually be detrimental to radical-right parties entering parliament while low thresholds would not. This is because radical-right parties are usually smaller and thresholds have the greatest impact upon small parties.

Previous chapters have already established that electoral rules until the 2004/2005 elections were similar in Romania and Bulgaria with proportional representation in both and only a slightly lower threshold of $3 \%$ in the former in the early part of the 1990 s versus $4 \%$ in the latter. This apparently small difference has had significant influence on radical-right success. PRM was able to enter parliament with roughly $3.5 \%$ of votes in the early $1990 \mathrm{~s}$, a score that would have prevented it from doing the same under a $4 \%$ threshold as in Bulgaria. In this chapter the effects of thresholds will be explored when analysing the European Parliament Elections of 2007 and 2008 the Romanian national elections ${ }^{131}$.

As has become custom, European elections in all states are perceived as nothing more than 'second order' in relationship to previous or upcoming national elections. Consequently, although the MPs are being elected to represent their constituencies in an EU supranational institution, the elections often become inundated with national issues rather than European ones. New members, such as the two countries studied here, are no exception to the rule and for this

\footnotetext{
${ }^{131}$ Bulgarian legislative elections will only occur in June 2009.
} 
reason, understanding the outcome in the European Parliament helps in understanding national issues in each state.

At the time of their accession, Romania sent five PRM members to the European Parliament while Bulgaria sent one ATAKA member. This relatively high number of nationalist radical-right MPs is what enabled the formation of ITS, a nationalist, xenophobic European Parliamentary group for ten months. The formation of ITS was considered by many to be a warning sign and an indication that the radical right in the East as well as in the West was on the rise. As will be explained below, this proved to be a misconception as the European Parliament elections in 2007 gave significantly different results. Both Romania and Bulgaria used the 5\% threshold as well as the D'Hondt formula in the elections of 2007 much like their Eastern European neighbours $^{132}$. And while Romania did not come back with any neo-fascist MPs in the November 2007 European Parliament elections, Bulgaria brought in 2 more, raising their number of Bulgarian ATAKA members in the European Parliament from 1 to 3 members.

To understand this apparent consolidation of ATAKA's presence (see also Fig. 5), it is important to understand the issues that surrounded the Bulgarian European parliament elections. Bulgaria's 2007 elections were dominated by a series of corruption scandals involving the governing Socialist Party as well as what was perceived by the population to be an increase in mafia crime across the country ${ }^{133}$. The higher vote for ATAKA, Bulgaria's far-right party, is not so much due to a drastic change in appeal or ideology but rather because of popular dissatisfaction over these issues. The ATAKA Party, with its anti-government and anti-

\footnotetext{
132 "European Election Database," Norwegian Social Sciences Data Service, 2006, available from http://extweb3.nsd.uib.no/civicactivecms/opencms/civicactive/en/Data. Internet; accessed 3 April 2009.

133 "Gloom and Graft mark Bulgaria's EU Election," Telegraph, May 21 2007, available from http://www.telegraph.co.uk/news/main.jhtml?xml=/news/2007/05/21/wbulg21.xml. Internet; accessed 3 April 2009.
} 
corruption message, was very successful in rallying citizens determined to give a warning to their current government. This resembles very much the 2005 elections in Bulgaria, discussed in the previous chapter, when ATAKA likewise capitalized on popular dissatisfaction with the corruption of the mainstream parties. This however was only a warning sign and by no means does it indicate a strengthening of the ATAKA vote in the long-term. As already mentioned previously, current opinion polls place ATAKA at just $5 \%$, an all-time low since its inception in 2005.

In the Romanian case, the 2007 European Parliament elections were highly publicised, in part by president Traian Basescu, who due to his constitutional prerogatives, had organized a referendum on the same date as the elections which asked citizens whether they agreed with a switch to the majoritarian electoral system starting with 2009 . In addition, candidates from the Democratic Party, supporting Basescu, managed to shift the centre of the election debate to one issue, the right of all EU citizens to travel and work within the EU without impediments ${ }^{134}$. As a result of voters' frustration over the issue but also due to their perceived correlation between EU integration and Basescu's presidency (as well as the PD), the centre-right Democrats had little trouble persuading the electorate and winning the election.

Surprisingly enough, neither Romanian radical right party, the well-established Greater Romania or the New Generation Party, managed to pass the threshold of $5 \%$. Having said this, the NGP fared extremely well and only fell short by $0.1 \%$ of sending MPs to the European Parliament. Nevertheless, the failure of both to make it to parliament was astonishing and was blamed on the inability of either party to offer a clear message on their own in light Basescu's

\footnotetext{
134 "Priorities of European MPs," BBC, November 25 2007, available from http://www.bbc.co.uk/romanian/news/story/2007/11/071125 prioritati_europarlamentari.shtml. Internet; accessed April 62009.
} 
popularity and dominance over political discussions on one issue. This, however, still fails to explain why six right-wing MPs entered the European Parliament in 2007 to begin with given the poor performance of the old radical right as well as NRR.

Subsequently, a closer look into the events surrounding the 2007 accession illustrate that the 6 seats reserved for Romania's and Bulgaria's far right in the European Parliament are by no means the result of an election in either state. Unlike their Central European partners in 2004, both countries found out that they would indeed join the EU in 2007 (and not 2008) only months before they did so, hence there was very little time for the organization of elections. As a consequence, the candidates from both countries were chosen hastily by the parliaments of each state for a limited duration, just until real elections could be organized later in 2007.

The six MEPs, therefore, did not come due to an election or a change in the preferences of voters in either country, but rather due to inter-party negotiations that took place on the eve of both nations' accession to the European Union. The percentage of radical-right MEPs that joined the Romanian and Bulgarian delegations was not even proportional to the percent of votes won in the previous election, nor was it equal to the same distribution of seats in their own national parliaments $^{135}$. Instead it was slightly larger, a result of the assertive positions on the part of these parties as well as carelessness on the part of the larger parties in both states, as they knew that the arrangement would last for less than one year. As a consequence, it is hard to draw any conclusions regarding a possible consolidation of the European Right with the advent of the two Eastern Balkan states joining the EU.

In fact, it is the 2007 European Parliament elections in both countries that speak volumes about the future of the European Right but also the radical right within each state. While

\footnotetext{
135 "European Elections, Romania," Parties and Elections, 2007, available from http://www.parties-andelections.de/romania.html. Internet; accessed 3 April 2009.
} 
Bulgaria's Ataka won 3 seats, in late May 2007, Ataka suffered enormously three months later, due to the departure of key members who accuse the leadership of nepotism, authoritarianism and who formed their own, albeit much less popular radical-right party ${ }^{136}$. The rupture within ATAKA, although not responsible for splitting the Bulgarian nationalist vote in half, does outline the increasing weakness of that party and foreshadows a lower performance in the upcoming 2009 elections and a lesser chance of passing the national or European Parliament election threshold of $5 \%$ in the future.

As previously mentioned, this failure to pass the $5 \%$ threshold is precisely one of the reasons why the Greater Romania Party did not gain seats in the Romanian European Parliament elections of November 2007. The New Generation Party, under charismatic football club owner and businessman George Becali, has managed to take advantage of the changing dynamics of Romania's political space quite successfully, therefore the supply element - that is to say, strong party leadership and leadership charisma, was just the right ingredient for success. However, just an adequate source of supply is not enough. The threshold seems to have been an important impediment to his party's ability to make it to the European Parliament. PRM was likewise affected by the 5\% limit. Albeit, as previously explained, PRM and NGP do have their own separate constituencies, it has been suggested that NGP has taken at least part of PRM's electorate $^{137}$. What has happened, therefore, is that the Romanian radical-right vote, which as of 2004 was representing roughly $10 \%$ of the population, was split almost in two with the rise of PNG with both parties taking their share. Ultimately, this has resulted in both being unable to enter parliament.

\footnotetext{
136 "Nationalist Group in Bulgaria Parliament Dented to 11," Novite, 2007, available from http://www.novinite.com/view_news.php?id=87261. Internet; accessed 10 December 2008.

${ }^{137}$ Dr Vlad Nistor, Romanian Diplomatic Institute - interview conducted in 2008.
} 
In future elections (both national as well as for the EP), it is very likely that the $5 \%$ threshold may be the one obstacle that not just PRM and PNG but also ATAKA and DSB may not be able to overcome. As for the ITS, by the end of 2007 it became clear that it was a short lived experiment, not because of its own dissolution weeks before the Romanian and Bulgarian elections, but because the means through which ITS has managed to rally over 20 members (the minimum needed for a political group to become official) were due to the special circumstances of the 2007 accession, rather than a surge in radical-right sympathy among voters in Eastern Europe.

Ultimately, the Bulgarian and Romanian cases in the 2007 European Parliament elections illustrate two important aspects. The first deals with party organization as ATAKA, PRM and PNG have proven that party capitalization on specific issues may create a window of opportunity for the radical-right; in retrospect, the lack of an effort at challenging the issues put forth by mainstream parties can seriously handicap the radical right as they cannot deliver a consistent message (as was the case in Romania). Secondly, the 2007 elections to the European Parliament demonstrate just how crucial even decimals of percentage points can be, as NGP missed the threshold by just $0.1 \%$ but yet sufficient enough to prevent it from entering the EP.

The importance of electoral rules is even more evident when analysing the impact that the new electoral law has had on the 2008 Romanian election. As mentioned earlier, Romanian President Traian Basescu successfully called the public to a vote on a new electoral law. The new law, despite its promotion as 'first-past-the-post', is somewhat of a hybrid between a majoritarian system and proportional representation.

Unlike a completely majoritarian system, the Romanian electoral system does not imply that 'the first past the post wins'. This is because while Romanian candidates could win an 
electoral district automatically if they could gather $50 \%$ plus one vote, those that did not had to wait until the votes were counted nationally and only then would votes be redistributed according to the national performance of each party ${ }^{138}$. By implication, this means that a candidate could make it to parliament even if he or she did not win a plurality in a certain electoral district if the national vote resulted in a better result for his/her party. Likewise, the system makes it possible for candidates to forfeit their seat even if they win the most votes in their electoral district if their party did poorly at the national level. This rather complicated hybrid-system made it, in essence, very hard for a candidate to secure one's seat in parliament since wining more than $50 \%$ of the votes is rather difficult given the plurality of parties competing. Ultimately, the system was for all intents and purposes still PR.

The population, however, was not socialized into thinking that the new electoral law was in actuality a modification of PR. All political leaders have called the system 'majortitarian' and this has had a serious impact on the voter. In other words, the voter was induced to engage in strategic voting just as one would proceed in a real majoritarian system ${ }^{139}$. Whereas before the voter chose the first party of choice, the prospect of a majoritarian system changed one's psychology inducing the voter to change one's preferences and vote for the second-best larger party if it has a realistic chance of winning, rather than waste the vote. There is a strong indication that this is precisely what happened during the 2008 elections and moreover the parties themselves seemed to have been aware that the new system would harm to their performance. When asked about his opinion on the semi-majoriarian system, Trache Nicolae Petre, secretary general of NGP, stated: "Of course for Romania it is a good thing. From now on

\footnotetext{
138 "Historical Archive of Parliamentary Election Results in Romania," Inter-Parliamentary Union, 2009, available from http://www.ipu.org/parline-e/reports/2262_A.htm. Internet; accessed 3 April 2009.

${ }^{139}$ Dr Vlad Nistor, Romanian Diplomatic Institute - interview conducted in 2008.
} 
people will run for office instead of some corrupt party with closed lists. But for us, given that we're still small, it can't be a good thing". The same opinion was shared by members of the $\operatorname{PRM}^{140}$

Electoral rules are therefore crucial for the success of the radical right and as illustrated above, they can be detrimental to the radical right if they tend to favour larger parties instead of smaller ones. This need not imply that NGP will necessarily be unsuccessful in the future or that the general trend alongside capitalist-authoritarian versus socialist-libertarian preferences is not one resembling the one in the West. However, strict institutional regulators such as electoral law may be crucial in keeping radical parties outside parliament as it has happened with the National Front in France.

In Bulgaria, where the system is still proportional representation but with the $5 \%$ threshold, the same prediction does not apply. Most likely, as the DSB will consolidate its position and as ATAKA will weaken, it is very likely that DSB will be an active player in Bulgarian politics provided institutional regulators do not change and the party itself will not miss chances to capitalize on surges in demand for radical-right messages.

\subsection{Conclusion}

In conclusion, both this chapter as well as the previous chapter illustrate the intricate relationship between demand and supply. A full explanation concerning the shifts observed during this time period, and indeed any explanation regarding election results, cannot be given just through an analysis of supply or just and analysis of demand. It is not only demand that

\footnotetext{
${ }^{140}$ Voicu Mihaita, Greater Romania Party - interview conducted in 2008.
} 
affects supply and vice versa but rather both variables are in their turn affected by other factors, namely the regulators (usually institutional) of the political market-place. Understanding these regulators is therefore crucial in understanding why the marketplace moves and shifts over time in the first place.

The regulator during the 1990 s and 2005 s was the prospect of EU integration as well as conditionality that influenced the necessary shift towards the centre of the mainstream left which allowed for the radical right of the communist past to consolidate. The regulators after 2005, are the foreign direct investment and lenient visa laws allowing migrants. These features have resocialized the voter in the working-place thus altering the demand towards NRR.

Nevertheless, institutional (this time meaning internal or state) regulators such as electoral law and thresholds have likewise proven quite important in preventing the success of the NRR and its ability to make it into government. It is important to note, however, that while the success of the NRR has been prevented, its very emergence and manifestation in Bulgaria and Romania is not something that institutional regulators such as threshold and electoral rules can thwart. Therefore, while the success of NRR parties is more related to institutional factors, the appearance of the NRR in general has more to do with changes in the demand which in turn have been precipitated by external regulators (in this case, EU integration and FDI).

Lastly, by focusing on Romania and Bulgaria, this chapter does not seek to imply that it is only these Eastern European states that have witnessed the appearance of NRR parties such as those in the west. Obviously the same societal changes that engulfed these two countries have also been present elsewhere in Central and Eastern Europe as well. Therefore, naturally this 
study is not reducing the emergence of the new radical right as a result of these societal changes to only these two countries.

However, for the purpose of this study, Romania and Bulgaria are unique because given the strong legacy of the communist party, it is these states alone that witnessed their political space oriented on an opposite two-dimensional axis compared to that of the West. Subsequently, now after their exposure to the same effects of the global market, it is again only these two that have witnessed the appearance of a hybrid between the two (Fig. 6). The reason for the formation of hybrid-political delineations along opposite two-dimensional axis is therefore exclusive to Bulgaria and Romania because of the nationalist nature of their communist past.

Finally, although the hybrid is still present and currently still accurately depicts the picture of the political space in the two states, this situation cannot be expected to remain unchanged. In fact, it is expected that with further integration, increasing FDI, and even higher numbers of migrants from Eastern European states towards Western Europe and thus, further resocialization of voters, the vote for the old radical right of the communist past will decrease over time while on the other hand, the vote for the new radical right will increase, provided all other variables are held constant. Ultimately, it is expected that as communist legacies will become less and less important over time, that the political space on the socialist-authoritarian versus capitalist-libertarian axis will disappear altogether. In the end, the only special arrangement of the political space in these states will be along the capitalist-authoritarian versus socialistlibertarian axis as it is currently in the West. 


\section{Chapter 6}

\section{Conclusion}

\subsection{Overview}

The radical right, often associated with racism, xenophobia, authoritarianism and intolerance, is a constant presence in the Western European political space. After the postcommunist revolutions of 1989, the radical right has entered Eastern European political life as well. Two countries in the East stand out in particular as the evolution of the radical right here has been dynamic and intricate and has been strongly linked with the nature of the communist past in these states.

Romania and Bulgaria, having experienced strongly nationalist communist regimes, are countries that have witnessed the emergence of radical parties that had a connection with and in fact, called for a return to - that very communist past. It is this aspect that makes these countries unique among all their Central and Eastern European (CEE) neighbors. This is because, while radical right parties are not limited to just Romania and Bulgaria, radical parties of the communist-past are nevertheless observed only in these two states. It is only here, that the radical right, despite the name right, involved parties that had a left position on economic issues due to the communist connection. For this reason, this thesis has focused on an in depth analysis of the evolution of this party-family in these countries rather than a description of the radical right in all Central and Eastern European states. Moreover, in many countries of the region, the radical right has been outright absent from politics altogether.

The evolution of the radical right in the two states is nonetheless, not just one of the old radical-right of the communist past. Instead, we have identified a progression from one type of radical right (that of the communist past) to a different type altogether (the new radical right 
similar to that seen in the West). As this study has demonstrated, this gradual progress can be divided into three main stages.

The first stage started right after the post-communist revolutions and lasted up until the middle of the previous decade. This stage is marked by the formation of the old radical right but also by a strong cooperation between the socialist or social-democratic party in power and the radical right. In both Romania and Bulgaria, again in stark contrast to their neighbors, the mainstream socialist parties that took over right after 1989 were not democratic pro-market and pro-reform parties but rather reinvented communist parties composed of numerous elements of the previous communist regimes. This made the cooperation between the two even more possible or as in the case of Bulgaria, this allowed the socialists to co-opt the radical right parties and take on the nationalist message themselves for a period of time. This stage ended only with the rise to power of reformist parties in the two states.

The second stage was marked by considerable changes in the political space of these states. As the reformist parties took power, the left realized it must overhaul its message and moved towards the centre, leaving even more room for the old radical right on the left of the political spectrum. This move was also accompanied by a commitment on the part of the mainstream left to avoid the creation of coalition or alliances with the radical right again. Consequently, the radical right was isolated politically as it lost any possible prospect of forming government as it did during the early 1990s. However, due to this isolation, its position as the almost sole occupant of the left (on economic issues) strengthened its chances of making it to government. As a result, this period was marked by a surge in the radical-right vote and an overall consolidation of the phenomenon in both states. 
Finally, the third stage is characterized by the most dynamic changes in the political space of these countries, some of which have not yet been completed and are still underway. This stage can be said to have approximately started after 2004 or 2005 . The years $2004-2005$ just like the previously mentioned year of 1995 (marking the year of change between the first and second stage) should only be understood as a rough approximation as sometimes Bulgaria and Romania have differed by one or two years (especially given the one year difference between the legislative elections in the two countries).

The third stage is marked by a drastic change in voter preferences but also by a recognition of this on the part of radical right parties and therefore a change in the supply as a result of these preferences. In other words, the demand-side and consequently the supply-side for the radical right shift radically. Whereas, before this, the demand was for a radical party of the communist past and thus a radical party that was authoritarian yet left on economic issues, the opposite is true after 2004; while the authoritarian element remains, the new radical right is a radical right of the actual economic right. In this respect, the special map of the demand for the new radical right resembles almost completely the situation in Western European countries.

The shift, however, as it is still underway, has not resulted in a total change in the political space but rather only in the change of some of the electorate, while the rest have maintained their preferences on the old socialist and authoritarian versus capitalist and libertarian axis. This has resulted in the arrangement of two axes on which voters and parties have aligned themselves on. One is the old socialist-authoritarian versus capitalist-libertarian axis that existed until the mid-2000s on which the old Greater Romania Party (PRM) and ATAKA still occupy a position at the socialist-authoritarian pole. The second is the axis resembling the political spectrum of the west; that is to say, a capitalist-authoritarian axis versus a socialist-libertarian 
one and this is where Democrats for a Strong Bulgaria (DSB) and New Generation Party (NGP) in Romania occupy the space at the capitalist-authoritarian end. The chronological picture of these changes is depicted in Fig. 7 below.

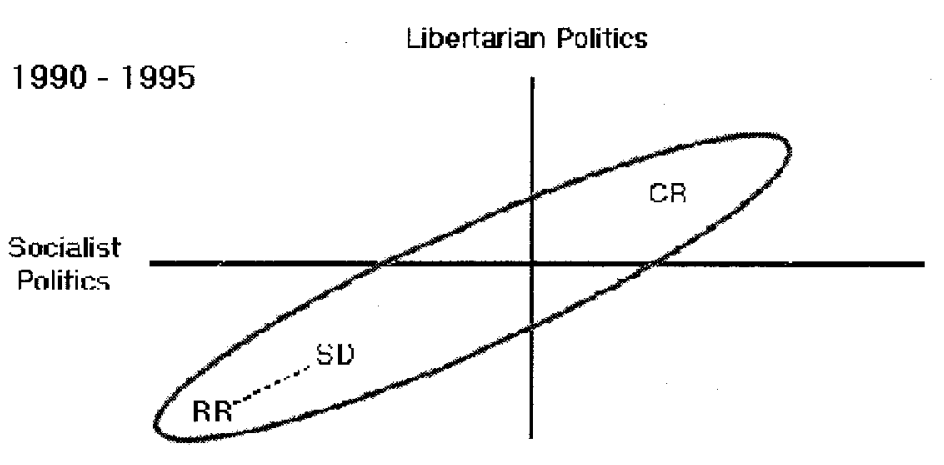

Authoritarian/Nationalist Politics

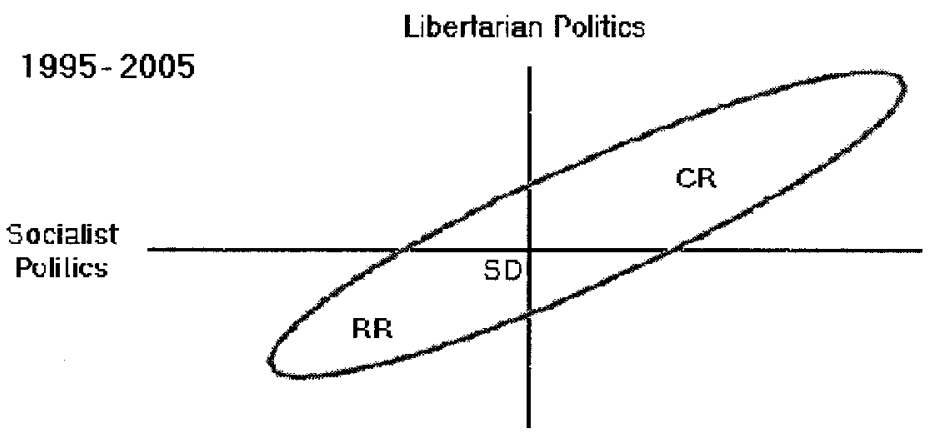

Aulhurilarian'Walionalis! Pulitics

$2005-$

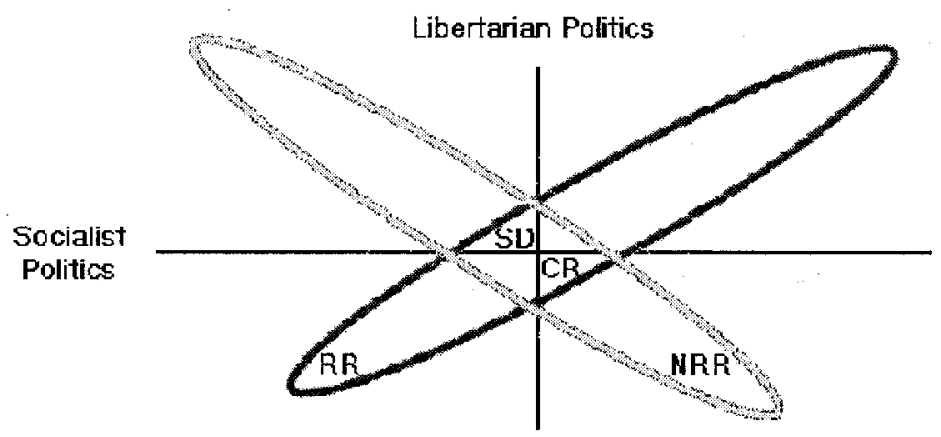

Authoritariany Nationalist Politics
Fig. 7 attempts to illustrate the volatility between 1990 and 2009 of the political Capitalist Politics

Capitalist between the two in the first Politics

Capitalist Politics second lighter line in the third graph (crossing the darker line).

Graphic Representation Developed by the Author Drawing on Conceptualization Provided by Kitschelt.

Fig 7. Chronology of the Shifts of the Romanian and Bulgarian Political Space between 1990 and 2009 (SD - social democrats, CR - centre right, RR - old radical right, NRR new radical right) 
Having outlined the shifts of the political space in these two states over time, it is important at this juncture to mention that understanding these changes as only the interplay between demand and supply without explaining what factors have shaped the demand and the supply would be incomplete at best, if not outright superficial. Certainly it is the interaction between the two that have produced the spatial arrangement outlined above, however if one is to understand the dichotomy between demand and supply as part of the electoral marketplace, one must have an appreciation for the regulators of this marketplace, which have influenced the alterations in demand and consequently in the supply for radical right parties.

This thesis has repeatedly tried to point out that the very existence of the radical right (be it the old communist-nostalgic kind or the new radical right after 2004) as well as its procession over time has been the result of past legacies, external factors and institutional electoral regulators. Chapter 3 has demonstrated that the establishment or lack of establishment of radical right parties of the communist past was strongly linked to the history of communism in these states. Consequently, in states where communism did not adopt a strong nationalist dimension, such parties did not form after 1989. Conversely, in countries where it did, such as Bulgaria and Romania, the radical right after the post-communist revolutions was able to take over this socialist yet nationalist message. The ability to successfully do this is however in great part due to the skill and charisma of the party leader. PRM in Romania versus the Bulgarian radical right are evident examples of the importance of effective strong leadership.

Chapter 4 illustrates that the changes in the political space which resulted in the strengthening of this old radical right was likewise due to a change in voter preferences induced by external regulators. Specifically, it was the prospect of EU integration as well as EU conditionality which has stimulated the electorate to seek parties that, unlike the social- 
democrats, promised quick reforms in line with EU requests and demands. Although the effects of EU conditionality were primarily on the mainstream parties, the old radical right suffered the indirect effects; namely, as the mainstream left was forced to move towards the centre (and promise reform and EU integration) if it hoped to be still an attractive option to the centre-right parties, the old radical right of the communist past was left alone in the left-pole of politics. This has been the primary reason for its ability to consolidate itself until $2004-2005$ since with the mainstream parties closer together on the political spectrum, the radical right parties could now essentially claim to be the only opposition. This was vivid in the 2000 Romanian elections when the PRM became the main opposition party.

Lastly, it is again the external regulators that have been responsible for the major shifts in the political space after 2005 as well. As the prospects of EU integration were materializing into a real chance of joining the Union by 2007 or 2008, foreign direct investments as well as preferential visa policies were becoming crucial influencing aspects of Bulgarian and Romanian voters. With the changing of the working-place environment from one in state-owned companies to one in multi-national corporations or abroad (due to the elimination of visas for Romanians and Bulgarians to Schengen states), the citizens' political preferences have been altered as well. Whereas before the voter (especially the blue-collar voter) made a link between the state and the company he or she worked for, now the link was made between the same company with the same rigid authoritarian working-environment and the capitalist corporate world. This has substantially altered their preferences, essentially rearranging them from a socialist-authoritarian versus capitalist-libertarian axis to a capitalist-authoritarian versus socialist-libertarian axis, similar to the situation in the West. The emergence of the new radical right in Romania and Bulgaria, advocating capitalism and a strong authoritarian state is the reflection of a 
renegotiation of the supply in light of the aforementioned societal changes. Once again, it is very important to stress that these changes occurred so quickly because of outside factors - the rapid increase in foreign direct investment after EU integration became a real option for these states as well as the sudden relaxation in visa-laws towards Western European states.

These events have, therefore, made the importance of the communist past and the way that the electorate and parties saw themselves in relation to it, less significant over time. Albeit making a slightly different argument about mainstream parties, Kitschelt and Smyth likewise agree that communist legacies, albeit important during the first years after democratization, seem to matter less and less over time ${ }^{141}$. The argument made in this thesis, that communist legacies likewise matter less and less over time when speaking of the radical right, are consistent with the findings of Kitschelt and Smyth.

This, however, is still not the whole picture, as internal regulators have repeatedly proven to crucial in either aiding, either obstructing the success of the radical right throughout the period studied. For example, it was the low electoral thresholds that allowed Greater Romania Party to enter parliament in the early 1990s. If Romania had only a slightly higher threshold similar to that in Bulgaria, then the Greater Romania party would have never attained seats in the Romanian senate or lower house. Although counterfactual, one can only speculate that had Bulgaria a lower threshold then the radical right would have been able to enter that nation's National Assembly much earlier than it did.

Similarly, it was the slightly higher threshold of 5\% in the European Parliament elections that prevented an NGP on the rise with a highly popular leader to send its representatives to that

\footnotetext{
${ }^{141}$ Herbert Kitschelt and Regina Smyth, "Programmatic Party Cohesion in Emerging Postcommunist Democracies: Russia in Comparative Context," Comparative Political Studies 35 (2002): 1252.
} 
parliament. It is again the change in electoral law that had a strong effect on the performance of the old as well as new radical right in the Romanian 2008 legislative elections. As that country has modified its electoral law from proportional representation to a hybrid-system combining elements of first-past-the-post with PR, the voters have been forced to renegotiate their choices. Whereas before the new electoral law, a 'strategic voting' did not generally dissuade the voter from voting for the first party of choice, now the elector may be more inclined to vote strategically for the second-best party that has an actual chance of making it to parliament. The second-best party here is often represented by a mainstream party while NGP and PRM are clearly fringe parties. This made them the evident targets of the new law. This disadvantage that NGP as well as PRM are now facing was obvious even in the minds of the actual party leaders and party members who themselves projected a poorer performance on the part of their own political parties in the upcoming elections.

Consequently, when

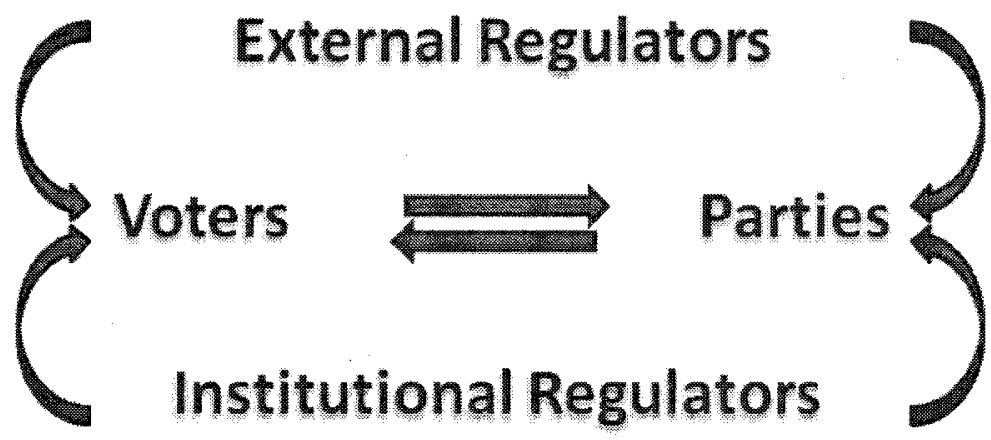
answering the question what accounts for the rise and consolidation of the radical right (old and new), one cannot respond by mentioning just one variable (supply, demand or regulators). Examples throughout this study have demonstrated that sometimes even if one variable is missing despite the presence of all others, the success of the radical right parties can be impeded. Therefore as this thesis has demonstrated, it is the interplay between the demand - supply and the institutional regulators as well as external regulators that have been responsible 
for the relative success of the radical right. Ultimately, it was the change in demand and subsequently in supply due to external forces under a political marketplace regulated by institutional rules of the game that have given the rise to and affected the development of radicalright parties in both Romania and Bulgaria.

\subsection{Theoretical Framework}

In the beginning of this study, one of the aims of this thesis (alongside an explanation for the rise of the new radical right in Romania and Bulgaria) was proclaimed to be a novel and updated theory on the radical right that would take into consideration its development in countries east of the Iron Curtain, especially the non-conventional communist-nostalgic radical right in Romania and Bulgaria. The following theoretical propositions regarding the radical right can be drawn from this study.

Firstly, radical right parties of the communist past advocating authoritarianism yet at the same time left-oriented politics are more likely to form in states with legacies of strong nationalist communists regimes rather than states without. This theory is not novel - it has been used in the case of Romania by Michael Shafir. However, this thesis has demonstrated that given Bulgaria's strong nationalist-communist past, it can be extended to this country as well.

Secondly, the role of communist legacies in shaping and influencing the radical right are likely to be stronger in the early years of post-communist democratization yet they are likely to become less important over time as other factors such as electoral/institutional or external become more important. 
Thirdly, holding internal institutions as a constant variable, external (supra-state) factors can impact both the demand as well as a renegotiation of the supply and alter the political space within a given state. Specifically in this particular case, EU conditionality is likely to alter voter preferences to demand pro-reform/pro-EU parties as well as alter party-supply to comply with the new demands - if the benefits include EU membership.

Fourthly, this thesis confirms the results of previous works by Kitschelt and Carter stating that the smaller the gap between the mainstream-left and mainstream-right on the political spectrum, the more likely it is for the radical right to consolidate. As it was shown, this is exactly what happened in the 2000 Romanian elections and the 2005 Bulgarian elections when the vote for radical right parties surged exactly because of the small spatial gap between mainstream parties.

Fifth, and related to the previous two conclusions, the higher the influence of EU conditionality on the mainstream-left, the higher are the chances for the latter to move towards the centre and leave an already existent radical right of the communist-past isolated yet much more consolidated in the left-authoritarian pole of politics. By implication, this suggests that the more isolated the radical right of the communist-past remains, the higher are its chances to be more successful because it now occupies the space it once shared with the mainstream-left.

Sixth, the prospect of EU integration is likely to speed up foreign direct investment as well as more relaxed visa laws which in turn speed up the re-socialization of workers and exposure to the international market. Consequently, the higher the degree of exposure to the international market, the higher are the chances of voters (but subsequently also of parties) to renegotiate their position along a new capitalist-authoritarian axis versus a socialist-libertarian 
axis much like in the West. Accordingly, in states with a nationalist-communist past, the above holds true but with the only mention that here, hybrid spatial arrangements form (alongside both axis) which over time materialize in the disappearance of the old socialist-authoritarian versus capitalist-libertarian axis.

Finally, for the purpose of a pan-European theory: the exposure to the international market through corporations or migration (that is to say, work abroad) is likely to alter the preferences of voters (but also the supply of parties) to pro-capitalist and authoritarian politics, regardless of previous arrangements of the political space. The success of a radical right party depends not just on the supply-side's ability to tap well into these new voter preferences but also on external regulators and internal regulators such as electoral laws favoring smaller parties. In essence, a successful new radical right party is well organized, under the leadership of a charismatic leader, with an electorate exposed to the effects of capitalism, while at the same time benefiting from a political environment with low electoral thresholds, proportional representation as well as from external regulators that promote the exposure to globalization and the international market.

These theoretical propositions basically confirm Kitschelt's own conclusions on the new radical party or NRR except with a few important additions. Firstly, the obvious addition is that this thesis suggests that the theories developed to explain the emergence of the NRR in Western Europe also apply to the for the Eastern NRR, regardless if the East was dominated until recently by quite different radical right parties advocating socialism and authoritarian politics instead of a free market. Secondly, exposure to the international market takes on here a broader understanding to include migration and therefore those that work abroad in similar authoritarian environments to blue-collar workers in large corporations as described by Kitschelt. This is 
somewhat novel as until now it was the inflow of immigrants that was considered a possible variable in research concerning the far-right in the countries receiving the immigrants. This study has shown that this inflow results in an exposure to the international market not just on the part of the natives but also on the part of the migrants who then take the xenophobic reaction of the natives to their own countries. Thirdly, the theoretical propositions emerging from this study are not made from a demand-side approach. Instead the conclusion is that all variables are necessary for the success of a radical right party: demand, supply and regulators (internal as well as external). It is an understanding of the interplay between those rather than just one that can give an explanation of the success or in retrospect, the failure of radical right parties in a given state and time.

\subsection{Outlook}

Looking towards the future this study will attempt to make a series of projections. First, as previously mentioned, it is the conclusion of this thesis that the radical right advocating capitalism and authoritarianism at the same time is a brand of extreme politics that is here to stay not just in Western Europe but in Eastern Europe as well.

Secondly, it has been the strong implication of this thesis that while the radical right of the communist past is currently sharing the title "radical right" with the NRR, it is expected that over time only the NRR will remain while the old radicalism to fall out of voters' preferences. This is because the spatial arrangement of politics in these states is likely to move more and more towards the new axis resembling the west rather than the old socialist-authoritarian versus capitalist-libertarian axis. 
Thirdly, electoral thresholds and electoral law have proven very influential. It is expected that wherever such laws favor smaller parties, the radical right will have higher chances of entering parliament. By contrast, stricter laws towards smaller parties will prevent them from doing so. As a result, if the constant electoral laws are kept in Romania and Bulgaria, it is the latter that is more likely to witness radical right parties in parliament rather than the former.

Fourth and finally, this thesis has not taken into the account the financial crisis of 2008 nor its effects in Western and Eastern Europe. This was because at the time when research was conducted, during the summer of 2008 , the crisis had not yet commenced. In fact, during that time, economic growth was very high in both countries; FDI was more substantial than in any other previous years and even the prospect of actual immigration from abroad was becoming more and more likely in order to meet the soaring demand for workers. This situation has changed significantly between the summer of 2008 and early spring of 2009. FDI has decreased, migrants from abroad have returned in light of decreasing employment opportunities while economic growth has turned into stagnation or recession almost overnight. As capital has left the two countries and plants and foreign-owned enterprises have closed or suspended their activities, it is unclear what future these enterprises may face.

Although this thesis is by no means attempting to make claims or projections related to the effects or length of the current financial crisis, one fact should be carefully considered. Just as the political space has been rearranged on a capitalist-authoritarian versus socialist-libertarian axis due to recent exposures to the international market, the withdrawal of capital, decrease in FDI and the possible renationalization of enterprises may again re-socialize voters but also the supply (that is to say, parties), arranging them on the previous socialist-authoritarian versus capitalist-libertarian axis. This statement is not true only of Bulgaria and Romania but can hold 
true of any other state as well. In this respect, Bulgaria and Romania are examples or "lessons to learned from" for the rest of European states. This is because the nature or nuance of radical right (communist-nostalgic versus NRR) is strongly related to the socialization of those exposed to authoritarian relationships at the workplace. In the case of the workplace being akin to the state, because it is state-owned then authoritarianism is associated with socialism. In the case that the workplace is not associated with the state but with international corporations and the global market then the authoritarian environment is associated with capitalism. A recreation of the stateowned enterprise through nationalization due to the financial crisis can result in the survival or even in the emergence of new radical right parties advocating authoritarianism yet leftist economic policies.

The threat of such a surge in the radical right is not at all exaggerated given the serious global economic situation. Historically, it is precisely these events that are the most unstable politically. It is after all in large part due to the Great Depression, that fascism and nationalsocialism came to power in the inter-war years.

For now, nevertheless, the radical right in Eastern Europe has been largely contained. It is no longer present in the Romanian parliament and encouraging signs do exist that it is losing ground in Bulgaria as well. For now. However, by no means can the party-family be expected to remain this way for a significant period of time. One of the reoccurring themes throughout this thesis has been that of constant change that the radical right is undergoing as a result of external factors, institutional constraints and alterations in demand or supply. Perhaps one of the implied insinuations of this thesis is that constant study of the radical right needs to be conducted in order to understand these very changes as they occur. This is true particularly of Eastern Europe were 
less studies exist and where the radical right is just as, if not even more active than in the West, because - as one can learn to appreciate - it is never all quiet on the Eastern front. 


\section{List of Interviews}

Professor Dr. Cristian Preda, Faculty of Political Studies Bucharest - interview conducted in Bucharest, 2008

Professor Dr. Vlad Nistor, Romanian Diplomatic Institute - interview conducted in Bucharest, 2008.

Trache Nicolae Petre, Secretary General New Generation Party - interview conducted in Bucharest, 2008

Tsvetan Tsvetanov, GERB Party Leader - interview conducted in Sofia, 2008.

Voicu Mihaita, Greater Romania Party (PRM) - interview conducted in Bucharest, 2008. 


\section{Bibliography}

"20 Principles of Ataka Political Party." ATAKA Political Party. 2009. Available from http://www.ataka.bg/en/index.php?option=com_content\&task=view\&id=14\&Itemid=27. Internet; accessed 3 April 2009.

Beichelt, T., and Minkenberg, M. "Explaining the Radical Right in Transition: Theories of Right-Wing Radicalism and Opportunity Structures in Post-Socialist Europe." Working Paper (2002): $1-25$.

Bell, John D. "The Radical Right in Bulgaria." In The Radical Right in Central and Eastern Europe Since 1989, edited by Sabrina P. Ramet and Roger Griffin, 233-254. State College: Pennsylvania State University press, 1999.

Carter, Elisabeth. The Extreme Right in Western Europe: Success or Failure? Manchester: Manchester University Press, 2005.

Casier, Tom. "The New Neighbours of the European Union: The Compelling Logic of Enlargement", In The Boundaries of EU Enlargement, edited by Joan DeBardeleben, 19-32. New York: Palgrave Macmillan, 2008.

Cibulka, Frank. "The Radical Right in Slovakia", In The Radical Right in Central and Eastern Europe Since 1989, edited by Sabrina P. Ramet and Roger Griffin, 109-131. State College: Pennsylvania State University press, 1999.

Comsa, Mircea. "Opinion Poll Barometer 2006" Study conducted on the part of Gallup Romania, Bucharest, Romania, October 2006. <http://www.gallup.ro/download/BOP31_oct2006.pdf> ; accessed 3 April 2009.

Datculescu, Petre. "Patterns of Voter Alignments in Present-Day Romania", In Cleavages, Parties, and Voters: Studies from Bulgaria, the Czech Republic, Hungary, Poland, and Romania, edited by Kay Lawson et. al., 261-274. Westport: Praeger, 1999.

"Democrats for a Strong Bulgaria Structure." Democrats for a Strong Bulgaria. 2009. Available from http://www.dsb.bg/display.php?show_category=1. Internet; accessed 3 April 2009.

Downs William and Miller Raluca. "The 2004 presidential and parliamentary elections in Romania." Electoral Studies 25 (2006):409-415.

"European Election Database." Norwegian Social Sciences Data Service. 2006. Available from http://extweb3.nsd.uib.no/civicactivecms/opencms/civicactive/en/Data. Internet; accessed 3 April 2009.

"European Elections, Romania." Parties and Elections. 2007. Available from http://www.parties-and- elections.de/romania.html. Internet; accessed 3 April 2009. 
"European Parliament Electoral Procedures." European Parliament. 2007. Available from http://www.europarl.europa.eu/facts/1_3_4_en.htm. Internet; accessed 3 April 2009.

"Foreigner Citizens. Demographic Balance for the year 2007 and Resident Population on 31th December - All countries of citizenship Italy" Italian National Institute of Statistics. 2008. Available from http://www.demo.istat.it/str2007/index_e.html. Internet; accessed 22 October 2008.

"George Becali." New Generation Party. 2008. Available from http://www.png.ro/conducere/89 Internet; accessed 31 November 2008.

"Gloom and Graft mark Bulgaria's EU Election." Telegraph. May 21 2007. Available from http://www.telegraph.co.uk/news/main.jhtml?xml=/news/2007/05/21/wbulg21.xml. Internet; accessed 3 April 2009.

Halman, Loek and Pettersson, Thorleif. "Religion and Social Capital in Contemporary Europe: Results from the 1999/2000 European Values Stduy", In Research in the Social Scientific Study of Religion, edited by David O. Mobeg and Ralph L. Piedmont, 65-94. Leiden: Brill, 2001.

Hitchins, Keith. Romania. Bucharest: Humanitas Press, 2004.

"Historical Archive of Parliamentary Election Results in Bulgaria." Inter-Parliamentary Union. 2009. Available from http://www.ipu.org/parline-e/reports/2045_A.htm. Internet; accessed 3 April 2009.

"Historical Archive of Parliamentary Election Results in Romania." Inter-Parliamentary Union. 2009. Available from http://www.ipu.org/parline-e/reports/2262_A.htm. Internet; accessed 3 April 2009.

Hunya, Gabor. "FDI in South-East Europe in the early 2000s." A study commissioned by the Austrian Ministry of Economy and Labour (2002): 1-28.

Hunya, Gabor. "Foreign Direct Investment in South-East Europe in the early 2003-2004." A study commissioned by the Investment Compact for South East Europe OECD (2004): 1- 36.

Karapin, Rogan V."Radical Right and Neo-Fascist Political Parties in Western Europe." Comparative Politics 30(2) (1998): 213-234.

Kitschelt, Herbert, and Anthony J. McGann. The Radical Right in Western Europe: A Comparative Analysis. Ann Arbor: University of Michigan Press, 1995.

Kostelecky, Tomas. Political Parties After Communism: Developments in East-Central Europe. Washington: Woodrow Wilson Center Press, 2002. 
“Lege nr. 68 din 15/07/1992 pentru alegerea Camerei Deputaților și a Senatului, Publicat in Monitorul Oficial 164(1992)." LegeStart. 2009. Available from http://www.legestart.ro/Lege-nr68-din-1992-(MTY5MjA-).htm. Internet; accessed 3 April 2009.

Lewis, P.G. "Democratisation and Party Development in Eastern Europe." Party Politics $1(3)(1995): 391-405$

Lewis, P.G. Political Parties in Post-Communist Eastern Europe. London: Routledge, 2000.

Lipset and Rokkan. Party Systems and Voter Alignments: Cross-National Perspectives. London: The Free Press, 1967.

McLaren Carstairs, Andrew. A Short History of Electoral Systems in Western Europe. UK: Lowe \& Brydone Limited, 1980.

Minkenberg, Michael V. "The Radical Right in Western Europe: A Comparative Analysis." The Journal of Politics 59(2) (1997):624-627.

Mudde, Cas. Populist Radical Right Parties in Europe. New York: Cambridge, 2007.

"Municipal Provisional Data as of January 1 2008." Spanish National Institute of Statistics. 2008. Available from http://www.ine.es/prensa/np503.pdf. Internet; accessed 28 October 2008.

"Nationalist Group in Bulgaria Parliament Dented to 11." Novite. 2007. Available from http://www.novinite.com/view_news.php?id=87261. Internet; accessed 10 December 2008.

"New Generation Party Doctrine." New Generation Party. 2008. Available from http://www.png.ro/dmdocuments/statut_PNG_RO.doc. Internet; accessed 31 November 2008.

Norris, Pippa. Radical Right: Voters and parties in the Electoral Market. NY: Cambridge University Press, 2005.

Ost, David. "The Radical Right in Poland", In The Radical Right in Central and Eastern Europe Since 1989, edited by Sabrina P. Ramet and Roger Griffin, 86-107. State College: Pennsylvania State University press, 1999.

"Priorities of European MPs." BBC. November 25 2007. Available from http://www.bbc.co.uk/romanian/news/story/2007/11/071125_prioritati_europarlamentari.shtml. Internet; accessed April 62009.

"Romania." CIA World Factbook. 2009. Available from https://www.cia.gov/library/publications/the-world-factbook/geos/ro.html. Internet; accessed 3 April 2009.

"Romania Parliamentary Chamber 1992 Elections." Inter-Parliamentary Union. 2009. Available from http://www.ipu.org/parline-e/reports/arc/2262_92.htm. Internet; accessed 3 April 2009. 
Shafir, Michael. "Marginalization or Mainstream? The Extreme Right in Post-communist Romania." In The Politics of the Extreme Right: From the Margins to the Mainstream, edited by Paul Hainsworth, 248-267. New York: Pinter, 2000.

Shopov, Vladimir. "How the Voters Respond in Bulgaria", In Cleavages, Parties, and Voters: Studies from Bulgaria, the Czech Republic, Hungary, Poland, and Romania, edited by Kay Lawson et. al., 187-202. Westport: Praeger, 1999.

Sitter, Nick. "Cleavages, Party Strategy and Party System Change in Europe, East and West", In Pan-European Perspectives on Party Politics, edited by Paul Lewis and Paul Webb, 179-205. Boston: Brill, 2003.

Spirova, Maria. "The Bulgarian Socialist Party: The long road to Europe." Communist and PostCommunist Studies 41(2008): 481-495.

Stefanova, Boyka. "Testing Theories of Radical Right Voting: Social Structure versus Political Agency and Electoral Support for the Attack Party in Bulgaria" Paper presented at the annual meeting of the American Political Science Association, Hyatt Regency Chicago and the Sheraton Chicago Hotel and Towers, Chicago, IL, Aug 30, 2007. Available from

$<$ http://www.allacademic.com/meta/p209637_index.html>; accessed 3 April 2009.

Vachudova, Milada Anna. "The Leverage of International Institutions on Democratizing States: Eastern Europe and the European Union." Robert Schuman Centre for Advanced Studies 33(2001): 1-33.

"Vote Intentions." Alpha Research in Bulgaria. 2009. Available from http://www.aresearch.org/electoral/1686.html. Internet; accessed 3 April 2009. 